HÉLDER ANTÔNIO REBELO PONTES

\title{
AVALIAÇÃO IMUNOISTOQUÍMICA DAS PROTEÍNAS METALOTIONEÍNA, PAKT e NF-kB COMO MARCADORES DE PROGNÓSTICO DE CARCINOMAS EPIDERMÓIDES DE BOCA
}


Hélder Antônio Rebelo Pontes

Avaliação imunoistoquímica das proteínas metalotioneína, pAKT e NF-KB como marcadores de prognóstico de carcinomas epidermóides de boca

Tese apresentada à Faculdade de Odontologia da Universidade de São Paulo, para obter o título de Doutor, pelo Programa de Pós-Graduação em Odontologia.

Área de Concentração: Patologia Bucal

Orientador: Prof. Dr. Décio dos Santos Pinto Júnior

São Paulo

2008 


\section{FOLHA DE APROVAÇÃO}

Pontes HAR. Avaliação imunoistoquímica das proteínas metalotioneína, pAKT e NFKB como marcadores de prognóstico de carcinomas epidermóides de boca [Tese de Doutorado]. São Paulo: Faculdade de Odontologia da USP; 2008.

São Paulo, ........................

\section{Banca Examinadora}

1) $\operatorname{Prof}(a) \cdot \operatorname{Dr}(a)$

Titulação:

Julgamento:

Assinatura:

2) $\operatorname{Prof}(a) \cdot \operatorname{Dr}(a)$

Titulação:

Julgamento:

Assinatura:

3) $\operatorname{Prof}(a) \cdot \operatorname{Dr}(a)$

Titulação:

Julgamento:

Assinatura:

4) $\operatorname{Prof}(a) \cdot \operatorname{Dr}(a)$

Titulação:

Julgamento:

Assinatura:

5) $\operatorname{Prof}(a) \cdot \operatorname{Dr}(a)$

Titulação:

Julgamento: Assinatura: 


\section{DEDICATÓRIA}

Dedico este trabalho à minha mulher Flávia, eterna tábua de salvação e à minha filha Ana Luísa, minha luz. 
Aos Meus queridos pais, Ariosto e Marizete. Meus exemplos de amor. 
Cualox das coisas nãa está no tempo em que elas duram, mas na intensidade com que acontecem. OPax issa existem momentos inesquecúveis, coisas inexplicáveis e pessoas incomparáveis. 


\section{AGRADECIMENTO ESPECIAL}

Décio, dizer que ter sido seu aluno foi mais que um prêmio é pouco, porque você soube encontrar, em cada situação, a mais pertinente técnica para comunicar sua mensagem e fazê-la inteligível, aliás, coisa típica de quem nasceu para ensinar. Sua preocupação em dar o melhor de si, deixou patente sua irrefutável vocação para o magistério. Ganhei eu, ganhamos todos. Por isso, nestas breves, mas sinceras palavras, o penhor de minha gratidão. Segundo Jean-Paul Sartre, "O homem nada mais é do que aquilo que faz de si mesmo", e você, Décio, fez-se um grande mestre. 


\section{AGRADECIMENTOS}

Profa. Dra. Suzana C.O.M. Sousa, ainda que haja tantas coisas a dizer, em matéria de agradecimento, como e por onde começar a falar sobre o que a senhora, professora, representou para a consolidação de meus conhecimentos, numa área tão importante quanto complexa? Tentarei aqui ser o mais objetivo possível. Deixando de lado o sentimentalismo demagógico, posso dizer que sua conduta como mestra, creia-me, não excedeu a minha expectativa, porque sua competência a coloca na extirpe dos grandes, zelosos, dedicados e sapientes mestres. Professora, devo-Ihe tanto que dizer apenas obrigado, seria, de minha parte, uma incomensurável ingratidão. Que Deus a proteja sempre!

Prof. Dr. Fabio D. Nunes, o convívio diário mostrou-me um modelo de pesquisador a ser alcançado por todos os pós-graduandos. Saiba que a distância territorial que nos separa não enfraquecerá a admiração e a amizade que tenho por você. Obrigado amigo.

Aos Professores da Disciplina de Patologia Bucal da Faculdade de Odontologia da Universidade de São Paulo: Profa. Dra. Marina Magalhães, Profa Dra. Marília Martins, Profa . Dra. Andréa Mantesso e Profa. Dra. Karem Ortega, meus mais sinceros agradecimentos pelos ensinamentos e incentivo.

Edna Toddai (in memorian) é extremamente difícil escrever sobre a pessoa que representou tão bem a figura de mãe. Guardarei seus ensinamentos e conselhos, pois sei que são valiosos e foram transmitidos com amor. Minha eterna gratidão.

Elisa e Zilda, vocês representam a essência da frase de Santo Agostinho: "Ser feliz é levar felicidade aos outros". Obrigado por tudo. 
Às funcionárias da FOUSP, que sempre com amizade e carinho me ajudaram a superar os obstáculos do cotidiano: Nair Pereira, Néia Barbosa, Patrícia Leonel e Beatriz Costa.

Amigo Sérgio Cury, William Shakespeare disse certa vez: "Eu aprendi que não importa quanta seriedade a vida exija de você, cada um de nós precisa de um amigo brincalhão para se divertir junto". O quanto nos angustiamos? $\mathrm{O}$ quanto estudamos? O quanto nos ajudamos? O quanto nos preocupamos e torcemos um pelo outro? E acima de tudo o quanto nos divertimos? Sinto falta das nossas conversas, mas agradeço a Deus a oportunidade de ter convivido com você. Obrigado irmão.

Amigo Marcos Squadrans, não esquecerei sua preocupação comigo e minha família durante o curso. Você é um daqueles amigos que confirma a assertiva de Machado de Assis: "A amizade sente-se não se diz". Obrigado por tudo.

Érika Pedreira, Brunno, Fernanda Yamamoto, Flávia Caló, Camila Rodinni, Fábio Coracin, Patrícia Adachi, Paulo Sérgio e Tessa, vocês tornaram atuais a frase de Antoine de Saint-Exupéry: "Num mundo que se faz deserto, temos sede de encontrar um amigo".

Aos meus queridos colegas de Pós-Graduação Tatiana Libório, Kívia Linhares, Márcia Campos, Thais Acquafreda, Marina Moura, Yonara, Juliana, Renata, Alexandra, Paulo Braz, Alexandre Fraige, Alexandre, Epicuro, mencionou que: Não é tanto a ajuda dos nossos amigos que nos conforta, mas o confiante saber de que eles nos ajudarão. Obrigado pelo carinho. 
Pontes HAR. Avaliação Imunoistoquímica das proteínas metalotioneína, pAKT e NFKB como marcadores prognósticos de carcinomas epidermóides de boca [Tese Doutorado]. São Paulo: Faculdade de Odontologia da USP; 2008.

\section{RESUMO}

O carcinoma epidermóide é a neoplasia maligna que ocorre com maior freqüência na boca. Os pacientes portadores desta neoplasia ainda apresentam um pobre prognóstico com índices de sobrevida, em cinco anos, variando de 20 a 40\% em vários estudos. Um grande número de trabalhos tem sido direcionado para identificar marcadores que auxiliem no direcionamento do tratamento e melhorem o prognóstico. A metalotioneína (MT) é uma proteína de baixo peso molecular, com alto conteúdo de cisteína e que está associada à resistência neoplásica a várias modalidades de tratamento, e que por isso tem sido estudada como fator prognóstico em uma variedade de neoplasias malignas humanas. O Fator Nuclear $к B$ desempenha um importante papel na ativação de genes que estão relacionados à imunidade, inflamação, sobrevida, apoptose, proteção celular à radiação e à quimioterapia. A proteína serina/treonina quinase Akt é um alvo downstream da quinase 3-fosfaditilinositol, desempenhando um importante papel na proliferação e no bloqueio da apoptose de células cancerígenas. Neste estudo, nós examinamos a expressão das proteínas MT, NF-kB e pAKT em 51 casos de carcinomas epidermóides de boca, através de imunoistoquímica, com a finalidade de investigar suas influências prognosticas, assim como estudar as correlações entre alguns fatores clínicos com a sobrevida. Os resultados mostraram uma associação estatisticamente significante entre a expressão pAkt e NF-kB e entre MT e NF-kB. Ao lado disso, nossos 
resultados mostraram que a expressão de pAkt está associada a um pior prognóstico. Nossos resultados, portanto, sugerem que a proteína pAkt pode ter implicações terapêuticas em carcinomas epidermóides de boca.

Palavras-Chave: carcinoma epidermóide, Akt, metalotioneína, NF-kB, sobrevida. 
Pontes HAR. Immunohistochemical evaluation of Metallothionein, pAkt and NF-kB proteins as prognostic factors of Oral Squamous Cell Carcinoma. [Tese de Doutorado]. São Paulo: Faculdade de Odontologia da USP; 2008.

\section{ABSTRACT}

Oral squamous cell carcinoma (OSCC) is the most frequent malignant tumor of the oral cavity. In spite of improved therapeutic procedures, patients with OSCC in advanced stage generally present a poor prognosis, with an overall 5-year survival rate that ranges from $20 \%$ to $40 \%$. An extensive effort has started to identify features of the oral tumors that predict treatment response and prognosis. The metallothionein (MT), a low-molecular weight protein with high cysteine content, seems to be related to neoplastic resistance to oncologic treatment and therefore has been studied as a prognostic factor for a variety of human malignant tumors. The nuclear factor $\mathrm{kB}$ (NF$\mathrm{kB})$ plays an important role in the activation of the genes that code for immunity, survival, inflammation, apoptosis and in the cell protection for radiation and chemotherapy. The serine/threonine protein kinase Akt is a downstream target of phosphatidylinositol-3-kinase and it plays a key regulator of cancerous cell growth. Therefore, we have examined the MT, NF-kB and pAkt expression in 51 samples of oral squamous cell carcinoma by immunohistochemistry in order to investigate their prognostic influence on oral cancer, as well as studying the correlations between clinical factors and patient survival. The results showed a significant association between pAkt and NF-kB and between MT and NF-kB expression in tumor tissue. Besides pAkt over-expression was found in OSCC clinical samples and its expression was significantly associated with a poor overall patient survival. In conclusion, our findings suggested that pAkt expression may have therapeutic implications in squamous cell carcinoma.

Keywords: metallothionein, NF-kB, pAkt, survival. 


\section{LISTA DE QUADROS E TABELAS}

Quadro 4.1 - Dados clínicos coletados. .71

Quadro 4.2 - Dados clínicos coletados. .72

Quadro 4.3 - Classificação clínica TNM .73

Quadro 4.4 - Estadiamento TNM .73

Quadro 5.1 - Imunomarcações das proteínas pAkt, metalotioneína e NF-kB. 79

Tabela 5.1 - Distribuição da presença das proteínas .80

Tabela 5.2 - Distribuição das proteínas avaliadas pelo Qui-Quadrado de Aderência com correção de Yates, GL=1

Tabela 5.3 - Avaliação da discordância na ocorrência de proteínas .82

Tabela 5.4 - Distribuição da proporção de sobreviventes e da taxa de risco em função do tempo .93

Tabela 5.5 - Variáveis preditoras pelo modelo de Cox. .96

Tabela 5.6 - Distribuição do tamanho do tumor (T) conforme a presença das proteínas .96

Tabela 5.7 - Distribuição da recidiva conforme a presença de pAkt. .97

Tabela 5.8 - Distribuição da recidiva conforme a presença de metalotioneína .97

Tabela 5.9 - Distribuição da recidiva conforme a presença de NF-kB. .98

Tabela 5.10 - Distribuição do tabagismo conforme a presença de pAkt. .98 
Tabela 5.11 - Distribuição do tabagismo conforme a presença de NF-kB. .98

Tabela 5.12 - Distribuição do tabagismo conforme a presença de metalotioneína. 


\section{LISTA DE FIGURAS}

Figura 5.1 - Imunoexpressão da proteína pAkt (Streptavidina-biotina 400X). .88

Figura 5.2 - Imunoexpressão da proteína pAkt (Streptavidina-biotina 200X). .88

Figura 5.3 - Imunoexpressão da proteína NF-kB (Streptavidina-biotina 200X)_........90

Figura 5.4 - Imunoexpressão da proteína NF-kB (Streptavidina-biotina 400X)_........90

Figura 5.5 - Imunoexpressão da proteína metalotioneína (Streptavidina - biotina 200X). 92

Figura 5.6 - Imunoexpressão da proteína metalotioneína (Streptavidina - biotina 400X). 


\section{LISTA DE GRÁFICOS}

Gráfico 5.1 - Distribuição da presença de proteínas... .80

Gráfico 5.2 - Interação entre as proteínas.

Gráfico 5.3 - Proporção de sobrevida em função do tipo de terapia, com ou sem cirurgia

Gráfico 5.4 - Proporção de sobrevida em função do estadiamento.

Gráfico 5.5 - Proporção de sobrevida em função do consumo de álcool

Gráfico 5.6 - Proporção de sobrevida em função da idade 45 anos.

Gráfico 5.7 - Proporção de sobrevida em função da localização da neoplasia. .85

Gráfico 5.8 - Proporção de sobrevida em função do sexo do paciente. .86

Gráfico 5.9 - Proporção de sobrevida em função do tabagismo .86

Gráfico 5.10 - Proporção de sobrevida em função da presença de pAkt.

Gráfico 5.11 - Proporção de sobrevida em função da presença de NF-kB. .89

Gráfico 5.12 - Proporção de sobrevida em função da presença de metalotioneína..

Gráfico 5.13 - Gráfico de Kaplan-Meyer da curva de sobrevida geral

Gráfico 5.14 - Cox survival hazard, variável cirurgia. .94

Gráfico 5.15 - Cox survival hazard de pAkt. .95

Gráfico 5.16 - Cox survival hazard, etilismo...... .95 


\section{SUMÁRIO}

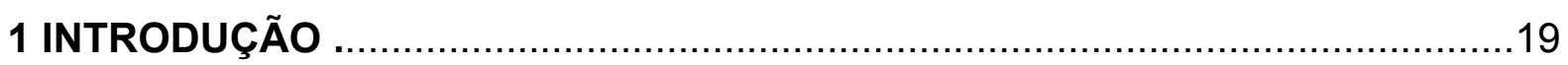

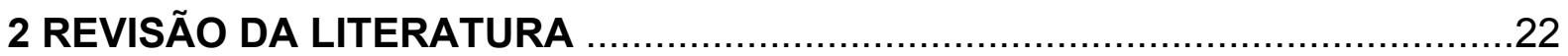

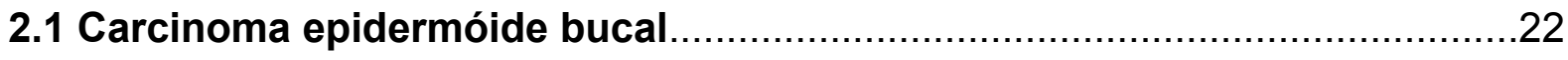

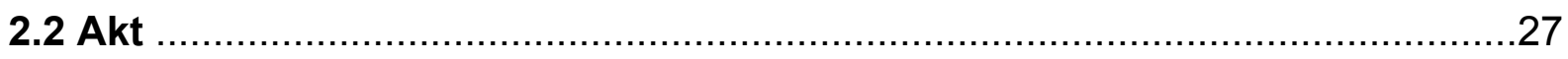

2.2.1 Relação da proteína Akt com as neoplasias malignas, com a sobrevida e com resistência às drogas antineoplásicas .......................................................... 36

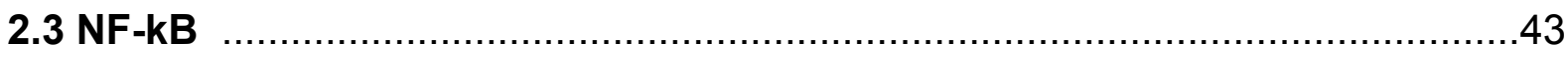

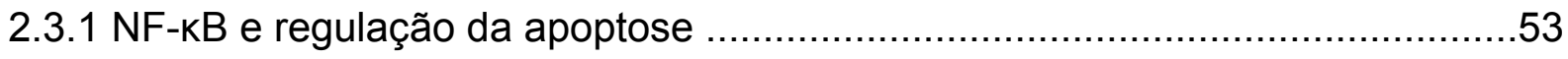

2.3.2 Regulação da proliferação, angiogênese, invasão e metástase........................56

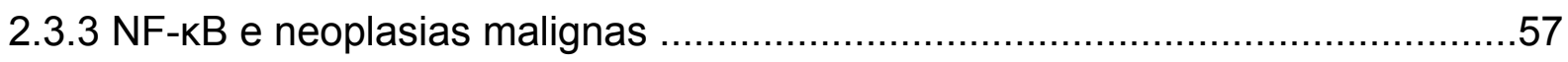

2.3.4 Relação da proteína NF-KB com a sobrevida e resistência às drogas anti-

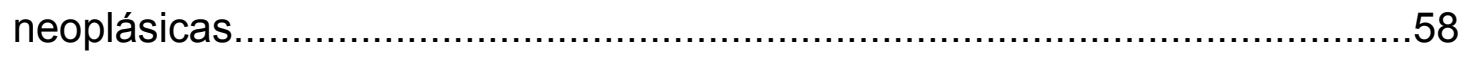

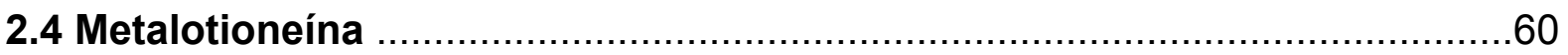

2.4.1 Funções do Zn Regulados pela metalotioneína..............................................66

2.4.2 Localização da metalotioneína na célula ...................................................67

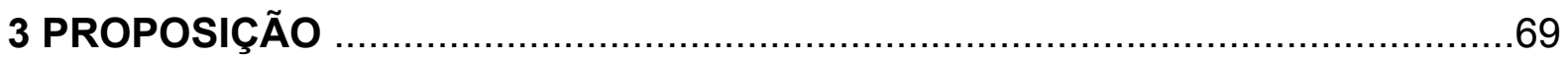

4 MATERIAL E MÉTODOS

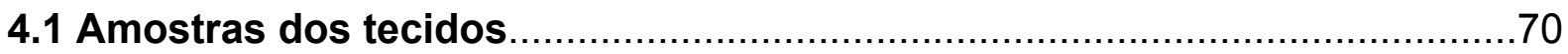

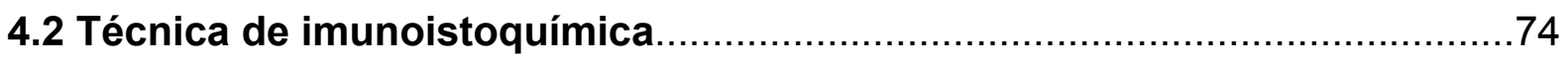

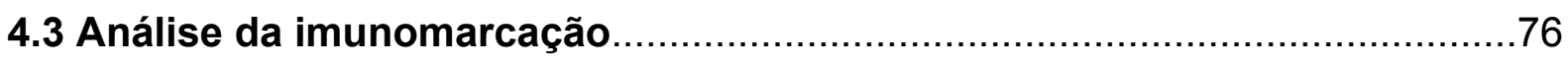

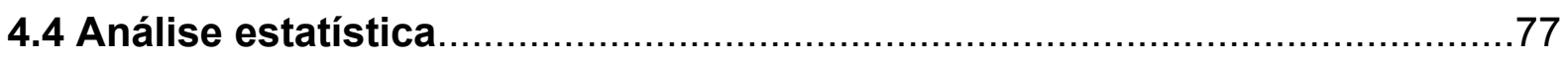

5 RESULTADOS

5.1 Imunomarcações das proteínas pAkt, NF-kB e metalotioneína......................79 
5.2 Distribuição da imunoexpressão das proteínas pAkt, NF-kB e metalotioneí-

na .80

5.3 Análise das variáveis clínicas em função da sobrevida. .82

5.3.1 Variável cirurgia. 82

5.3.2 Variável estadiamento. .83

5.3.3 Variável etilismo 83

5.3.4 Variável idade $\geq 45$ anos. .84

5.3.5 Variável localização (língua e soalho). .85

5.3.6 Variável sexo. .85

5.3.7 Variável tabagismo .86

5.4 Análise das proteínas pAkt, NF-kB e metalotioneína em relação à sobrevida. .87

5.4.1 Variável pAkt. .87

5.4.2 Variável NF-kB. 89

5.4.3 Variável metalotioneína. .91

5.5 Análise da curva de sobrevida. .93

5.6 Análise do modelo de risco proporcional de Cox. .94

5.7 Variáveis preditoras pelo modelo de Cox. .96

5.8 Distribuição do tamanho do tumor $(T)$ conforme a presença das proteínas .96

5.9 Distribuição da recidiva conforme a presença de pAkt. .96

5.10 Distribuição da recidiva conforme a presença de metalotioneína. .97

5.11 Distribuição da recidiva conforme a presença de NF-kB .97

5.12 Distribuição do tabagismo conforme a presença de pAkt.. .98

5.13 Distribuição do tabagismo conforme a presença de NF-kB. .98 
5.14 Distribuição do tabagismo conforme a presença de metalotioneína. .99

6 DISCUSSÃO. 100

7 CONCLUSÕES. 118

REFERÊNCIAS

ANEXO A. 


\section{INTRODUÇÃO}

O carcinoma epidermóide é a neoplasia maligna mais comum que afeta a boca. A despeito dos recentes avanços na cirurgia, na quimioterapia e na radioterapia, o prognóstico dos pacientes portadores dessa neoplasia não tem melhorado, com a taxa de sobrevida em cinco anos ficando em torno de 30 a 50\%, em várias partes do mundo (CHIN et al., 2005; VORA et al., 2003).

A avaliação prognostica e decisões sobre estratégias de tratamento são baseadas, hoje, principalmente no sistema TNM (do inglês tumor, nodal, metástase). Tais fatores clínicos possuem, entretanto, somente limitado valor prognóstico para o carcinoma bucal. É importante identificar novos marcadores prognósticos que reflitam a agressividade da doença para fornecer caracterização terapêutica para os pacientes (VORA et al., 2003).

O fator de transcrição kB (NF-kB- do inglês Nuclear factor kB) está envolvido na ativação de genes e tem sido primariamente relacionado às respostas imunes e inflamatórias. NF-kB participa, também, de um conjunto de atividades celulares relacionadas à morte, crescimento e desenvolvimento celulares. A esse fator de transcrição tem-se dado grande relevância, tanto na iniciação como na progressão de vários tipos de neoplasias malignas, por ser fundamental na regulação da expressão de genes importantes que afetam a proliferação celular, invasão, angiogênese e metástase. Supressão da atividade de NF-KB tem mostrado reprimir o crescimento de uma variedade de células neoplásicas tanto em cultura como em camundongos. Além disso, à atividade antiapoptótica de NF-KB tem sido atribuído 
um saliente papel na resistência das neoplasias malignas não só aos agentes quimioterápicos, como à radioterapia (ROSS et al., 2004; SUH; RABSON, 2004).

A Metalotioneína (MT) é uma proteína rica em cisteína, com peso molecular de aproximadamente 6000 Da com a capacidade de seqüestrar ou doar metais, e realizar, assim, um importante papel na atenuação ou amplificação da transdução de sinais no interior das células. Vários estudos sugerem um papel das MTs no desenvolvimento, resistência ao tratamento e no prognóstico de várias neoplasias malignas. Nesse sentido, muitos trabalhos mostram um aumento da expressão da MT em neoplasias de mama, cólon, rins, fígado, pulmão, ovário, próstata e tireóide. Esses efeitos se devem a capacidade da MTs de neutralizar sinais apoptóticos externos, assim como de seqüestrar agentes alcalinos, o que fornece resistência a drogas utilizadas na quimioterapia (CHERIAN; JAYASURYA; BAY, 2003; KIM et al., 2003; SATO; KONDOH, 2002; THEOCHRRIS et al., 2004).

A proteína pAkt/PKB faz parte da cascata de ativação da proteína PI3K (quinase 3-fosfaditilinositol) por uma variedade de fatores de crescimento. Substrato de Akt como BAD, caspase, FKHR e FKHRL1 são componentes promotores de morte celular e inibição desses alvos promove sobrevida. Por outro lado, a via do Akt aumenta proliferação celular ao induzir localização citoplasmática de algumas proteínas como mdm2 e p21 $1^{\text {Cip/WAF1 }}$ (ZHOU et al., 2001). Inúmeros estudos demonstraram a participação da proteína pAkt em carcinomas de mama, endométrio próstata e pâncreas (CHADHA et al., 2006; CLARK et al., 2002; HU et al., 2003; LESSARD et al., 2003).

A expressão das proteínas NF-kB, pAkt e MT não é igual em todos as neoplasias humanas, mas parece depender do nível de diferenciação, das mutações acumuladas, do índice de proliferação e do local de origem das neoplasias 
(CHERIAN; JAYASURYA; BAY, 2003; LEE et al., 2005). A reação imunoistoquímica, nesse contexto, tem se mostrado uma técnica extremamente útil para associar as proteínas celulares aos aspectos clínicos e histológicos das diversas neoplasias humanas (LEE et al., 2005; LIM et al., 2005; NAKAYAMA et al., 2001).

A proposta deste trabalho é verificar a associação da expressão das proteínas metalotioneína, pAKt e NF-kB, analisada através de imunoistoquímica, e de alguns aspectos clínicos com a sobrevida de 51 pacientes com carcinomas epidermóides de boca. 


\section{REVISÃO DA LITERATURA}

\subsection{Carcinoma epidermóide bucal}

Conforme dados do Instituto Nacional do Câncer (INCA), órgão do ministério da Saúde, o carcinoma de boca figura como a sexta mais comum neoplasia maligna, no Brasil, e para 2006, esperavam-se mais de 13 mil casos novos. O mais comum tipo de neoplasia maligna bucal é o carcinoma epidermóide, o qual é responsável por nove em dez lesões malignas diagnosticadas (LIM et al., 2005).

A situação do tratamento do carcinoma de boca é particularmente grave, visto que a maioria dos casos é diagnosticada tardiamente. A prevenção e o diagnóstico precoce são medidas eficazes para melhorar o prognóstico do carcinoma de boca. $\mathrm{O}$ diagnóstico precoce das neoplasias não deveria apresentar grandes dificuldades, uma vez que os grupos de maior risco são bem conhecidos e a região é de fácil acesso ao exame clínico, dispensando qualquer tipo de equipamento especial, além do fato de lesões com potencial maligno poderem ser diagnosticadas e tratadas antes da aquisição do fenótipo maligno. No entanto, observa-se que os pacientes, por não serem devidamente esclarecidos, negligenciam os sintomas, e os profissionais da área de saúde, por seu turno, não examinam rotineiramente a mucosa bucal.

O tabaco possui um papel bem estabelecido na etiologia do carcinoma epidermóide bucal. Em diversos estudos epidemiológicos, ficou claramente demonstrado não somente o alto risco de carcinoma de boca nos tabagistas, como 
também um notável efeito dose-resposta (KARI et al., 1997). O tabaco chega a aumentar de quatro a dez vezes o risco de desenvolvimento de carcinoma epidermóide. Ademais quando o álcool está associado ao tabaco, o risco de desenvolver a malignidade pode chegar a 15 vezes (VARGAS et al., 2000). Jaber et al. (1999) afirmaram que o risco de desenvolvimento de displasia epitelial bucal diminui consideravelmente em pacientes que param de fumar por um período acima de 10 anos. Adicionalmente, o hábito de mascar tabaco, misturado com folhas de betel, é considerado como um dos maiores fatores de risco para o carcinoma epidermóide bucal em alguns países asiáticos como Índia, Paquistão e Sri-Lanka (LEWELLYN; JOHNSON; WARNAKULASSURYIA, 2001).

São encontrados no fumo inúmeros componentes químicos com poder comprovadamente carcinogênico. Esses compostos podem ser divididos em três grupos distintos: as nitrosaminas, presentes na fumaça produzida pela queima do fumo, os benzopirenos, que se apresentam sob a forma de partículas, e as aminas aromáticas, derivadas da nicotina. A nicotina é o maior constituinte do tabaco, sendo responsável por causar sua dependência. Especula-se que as nitrosaminas derivadas da nicotina, especialmente a nitrosamina $\mathrm{N}$ - nitrosonornicotina (NNN) e a 4- (metilnitrosamina -1-(3-piridil) -1- butanona (NNK) participam da carcinogênese do tabaco. A nicotina atua inibindo a apoptose ao controlar a ação de enzimas proteína kinase $\mathrm{C}$ e a proteína nitrogênica ativadora de kinase. Ao lado desses efeitos, a nicotina modula os fatores de crescimento TNF- $\alpha$ (fator de necrose tumoral $\alpha$ ), PDGF (fator de crescimento derivado de plaquetas) e TGF- $\beta$ (fator de crescimento transformante $\beta$ ) que, em conjunto, estimulam a proliferação celular (PRADO; TAVEIRA, 2003). 
Os componentes químicos carcinogênicos presentes no tabaco apresentamse como pró-carcinógenos, necessitando de enzimas, como oxigenases do citocromo p450 e peroxidases, que os convertam em um reagente eletrofílico, com deficiência de elétrons em determinadas regiões da molécula, com força para estabelecer ligação mais estável, covalente, com as macromoléculas intranucleares do DNA (CANTO; DEVESSA, 2002).

Ao consumo de álcool é atribuído um papel de promotor nos carcinomas epidermóides bucais, por promover um efeito sinérgico com o tabagismo. O exato mecanismo como o consumo de álcool resulta na elevação do risco de desenvolvimento de carcinoma bucal permanece obscuro, pois os consumos de fumo e álcool em geral coexistem nos indivíduos. Alguns mecanismos têm sido propostos: o álcool pode atuar como solvente, facilitando a passagem dos carcinógenos através da membrana celular; o etanol pode alterar enzimas microssomais envolvidas no metabolismo dos carcinógenos no fígado, e também ativar substâncias carcinogênicas, ou ainda ocasionar uma alteração do metabolismo intracelular das células epiteliais, que pode ser agravado por deficiências nutricionais. Entretanto, o etanol, isoladamente, não foi provado ser carcinogênico para a mucosa de boca (WARNAKULARIYA et al., 2008).

A neoplasia acomete, geralmente, pacientes a partir da sexta década de vida, sendo que pacientes com menos de 45 anos são considerados jovens (LAM; LOGAN; LUKE, 2006). Os homens são mais acometidos que as mulheres em uma proporção de 3 - 2:1, proporção esta que vem diminuindo com o passar dos anos, em função do aumento, entre as mulheres, do consumo de tabaco e álcool. A relação do aumento do carcinoma epidermóide de boca com a idade ocorre tanto pelo fato do simples aumento do tempo de exposição do indivíduo ao carcinógeno, 
quanto pela alteração no equilíbrio metabólico e hormonal do indivíduo que propicia falha na defesa contra os processos de iniciação e promoção (CANTO; DEVESSA, 2002; CHEN; LIN; LIN, 1999; DURAZZO et al., 2005; HUSSEINNY et al., 2000; VORA et al., 2003).

A língua, seguida do assoalho bucal, é o sítio mais comum de origem do carcinoma epidermóide bucal, com valores em torno de 50\% das amostras em vários estudos, sendo o principal local, também, nos pacientes que não apresentam o hábito de fumar e naqueles pacientes considerados jovens (ANTUNES et al., 2001; CANTO; DEVESA, 2002; HUSSEINY et al., 2000; LAM; LOGAN; LUKE, 2006; VORA et al., 2003).

Em relação aos fatores prognósticos, as margens cirúrgicas, a localização e o hábito de fumar são indicadores prognósticos independentes (HUSSEINY et al., 2000). Segundo Lam, Logan e Luke (2006) e West, Castillo e Dennis (2002), a localização anatômica da lesão deve ser considerada como uma indicadora de prognóstico, já que os tumores apresentam comportamentos diferentes dependendo da localização anatômica. Para os primeiros autores, a língua e o assoalho bucal conduzem a um pior prognóstico, em função da maioria dos casos que acometem tais localizações se apresentarem com grandes dimensões.

A quantidade de carcinógenos na saliva, em certas regiões da boca, tem sido proposta como uma das explicações para a gravidade e para a maior freqüência da localização do carcinoma epidermóide ao longo da superfície lateral e ventral da língua (SCULLY; FIELD; TANZAWA, 2000). Essas localizações podem ser consideradas de risco porque recebem a maior concentração dos agentes carcinógenos do fumo. Além disso, a ausência de queratina nessas regiões pode contribuir para a vulnerabilidade dos tecidos aos carcinógenos. Em contraste, a 
presença de queratina tem sido sugerida como protetor da gengiva para os efeitos carcinógenos do fumo de tabaco (SCULLY; FIELD; TANZAWA, 2000).

Uma dieta que inclua peixe fresco, vegetais ricos em betacarotenos, vitamina C e vitamina $E$ tem sido associada com redução do risco de desenvolvimento de carcinoma epidermóide de boca. O tecido responde à agressão pelos carcinógenos do fumo através do processo de detoxificação ou antioxidação. Isso se processa por meio da ação das enzimas glutation-transferase (GST) e superoxidodismutase (SOD). Especula-se que uma maior ingestão de vitaminas antioxidantes (vitaminas A, C e E) melhore essa condição (CANTO; DEVESA, 2002).

Para Lam, Logan e Luke (2006), o estadiamento clínico TNM (tumor/nodal/metástase) é um sistema internacional importante para o registro de carcinoma, avaliação prognostica, formulação do plano de tratamento e comparação dos resultados do tratamento, sendo considerado como um dos melhores indicadores de prognóstico do carcinoma epidermóide bucal. Entretanto, para Haddadin et al. (2000), a classificação clínica TNM define o tumor primário em apenas duas dimensões, sugerindo que uma terceira dimensão, espessura tumoral ou a profundidade de invasão sejam consideradas como fatores de risco para metástases cervicais.

A escolha do tratamento depende da localização e do tamanho do tumor primário, da idade e saúde geral do paciente, da morbidade associada ao tratamento, da experiência e habilidade do cirurgião e do radiologista oncológico, além dos anseios do paciente (HUSSEINY et al., 2000). Convém ressaltar que a radioterapia é a terapia de eleição para os casos avançados, independente do sítio bucal de acometimento, complementada, quando possível, com a cirurgia, ou mesmo associada à quimioterapia (HADDADIN et al., 2000). 
Para Shingaki et al. (2003) a utilização de quimioterapia antes da cirurgia aumenta os índices de sobrevida e diminui consideravelmente a taxa de metástases à distância, quando comparado com seu uso após a cirurgia, e tem, como principal vantagem, a possibilidade de controle subclínico das metástases à distância. Os autores afirmam, ainda, que o uso de quimioterapia sistêmica adjuvante deve ser amplamente considerado em pacientes com envolvimento dos linfonodos.

\section{2 pAkt}

A proteína PKB/AKT foi caracterizada após o isolamento de dois genes chamados akt1 e akt2, identificados como homólogos do oncogene v-akt, o qual é sabido ser responsabilizado por um tipo de leucemia em camundongos. Posteriormente, dois estudos independentes revelaram que v-akt e seus genes homólogos codificavam uma proteína quinase que guardava semelhança com a proteína quinase C (VARA et al., 2004; WEST; CASTILO; DENNIS, 2002). A nova proteína foi chamada, então, de RAC (do inglês related to A and C kinases) ou PKB (do inglês protein kinase B) (NAVOLANIC; STEELMAN; McCUBREY, 2003; OGAWARA, 2002). Proteínas homólogas a Akt têm sido identificadas em uma variedade de espécies, incluindo pássaros, insetos e leveduras (KANDEL; HAY, 1999).

As três maiores isoformas de Akt/PKB, encontradas em células de mamíferos, são codificadas por três diferentes genes. Akt1, ou $\mathrm{PKBa}$, foi a primeira isoforma isolada, Akt2/PKBß e Akt3/PKBy foram posteriormente clonadas (CLARK et al., 
2002; NAVOLANIC; STEELMAN; McCUBREY, 2003; OGAWARA, 2002). Embora existam três isoformas de Akt, suas diferentes funções não foram completamente elucidadas (DAVID et al., 2004). Todos os subtipos de Akt/PKB parecem compartilhar substratos similares, além de todos serem expressos em mamíferos, embora os níveis de expressão sofram variação entre os tecidos (MEIER et al., 1997).

Akt1/ PKBa é o tipo predominante na maioria dos tecidos (KANDEL; HAY, 1999; LUO; MANNING; CANTLEY, 2003). Akt1 e Akt2 são expressas no cérebro, timo, fígado, coração, rins e pulmão e Akt3 no cérebro e testículos (MEIER et al., 1997; SHAH et al., 2005).

Todos os três genes de Akt possuem mais de $85 \%$ de identidade seqüencial e seus produtos protéicos possuem a mesma organização estrutural (HAY, 2005; VARA et al., 2004). Possuem um domínio PH (do inglês pleckstrin homology), com cerca de 100 aminoácidos na região N-terminal, responsável pela ancoragem aos fosfolipídios da membrana, seguido por um domínio catalítico relacionado à proteína quinase A e C e uma região regulatória C-terminal. Os resíduos treonina 308, localizados no domínio catalítico, e serina 473, localizado na região C-terminal, juntamente com domínio $\mathrm{PH}$, são críticos para a ativação de Akt/PKB (ANDJELKOVIC et al., 1997; JENSEN; HUNTER, 2001; KANDEL; HAY, 1999; TSURUTANI et al., 2005; VARA et al., 2004). Meier et al. (1997) acrescentam, entretanto, que os aminoácidos treonina 308 e serina 473 são os locais de ativação de Akta e os resíduos treonina 309 e serina 474 são os sítios de fosforilação de Aktß e que a fosforilação desses resíduos é evitada por uma substância chamada Wortmannin. 
A proteína Akt/PKB faz parte da cascata de ativação da proteína PI3K (quinase 3-fosfaditilinositol), por uma variedade de fatores de crescimento, incluindo fator de crescimento insulina, fator de crescimento epidermal, fator de crescimento de fibroblastos, interleucinas 3 e 6 e fator de crescimento do endotélio vascular (CLARK et al., 2002; MEIER et al., 1997; SHAH et al., 2005).

PI3K são heterodímeros compostos de uma subunidade catalítica, denominada p100, e uma subunidade adaptadora/regulatória, denominada p85 (JENSEN; HUNTER, 2001; MAYO; DONNER, 2002; NAVOLANIC; STEELMAN; McCUBREY, 2003). Ativação de PI3K deve ser acompanhada da ativação do receptor tirosinoquinase ou através da ativação de ras, que pode diretamente ativar a subunidade p110 com ausência de feitos sobre p85 (NAVOLANIC; STEELMAN; McCUBREY, 2003; VAZQUEZ; SELLERS, 2000).

A ligação da subunidade 85 kDa ao receptor traz a subunidade catalítica 110 , kDa de PI3K próximo à membrana celular onde esta subunidade catalisa a fosforilação do fosfolipídioinositol produzindo PIP3 (do inglês phosphatidyllinositol (3,4,5)-trisphosphate). Em resumo, a subunidade adaptadora permite ativação alostérica da subunidade catalítica de PI3K, ou seja, ativação pela região da molécula enzimática que não representa o grupo ativo (HAY, 2005; JENSEN; HUNTER, 2001; KANDEL; HAY, 1999; MAYO; DONNER, 2002; VARA et al., 2004; WEST; CASTILO; DENNIS, 2002).

Ativação de PI3K, como mencionado anteriormente, permite a fosforilação de uma proteína chamada PIP2 (do inglês phosphatidylinositol-4,5-biphosphate), no grupo 3'-OH, levando a produção de PIP3 em poucos segundos (JENSEN; HUNTER, 2001). PIP3 é um mediador lipídico que recruta proteínas que contenham 
um domínio PH (do inglês pleckstrin-homology) como Akt e PDKs (do inglês PtdIns(3,4,5) $\mathrm{P}_{3}$ - dependent kinases) (MAYO; DONNER, 2002).

Ligação de PIP3 ao domínio PH induz uma alteração conformacional de Akt e seu recrutamento do citosol para a superfície interna da membrana plasmática, com conseqüente exposição de seus sítios de fosforilação treonina 308 e serina 473 (ANDJELKOVIC et al., 1997; BROGNARD et al., 2001; MAYO et al., 2002; MEIER et al., 1997; NAVOLANIC et al., 2003; VAZQUEZ; SELLERS, 2000; WEST; CASTILO; DENNIS, 2002). A translocação de Akt para a membrana plasmática é rápida, ocorrendo em dois minutos após estimulação por IGF (ANDJELKOVIC et al., 1997).

Na superfície interna da membrana plasmática encontra-se a proteína PDK1 (do inglês 3-phosphoinositide-dependent kinase), que é constitutivamente ativada (HAY, 2005; MAYO et al., 2002). Navolanic et al. (2003), entretanto, relataram, em seu artigo de revisão, que a proteína PDK1 é uma proteína recrutada para a membrana plasmática por PIP3, e Vazquez e Sellers (2000) relatam que a ativação de PDK1 é patrocinada por PI3K.

PDK1 uma vez na membrana plasmática fosforila Akt no seu resíduo T308, ativando-a (pAkt) (BROGNARD et al., 2001; HAY, 2005; TSURUTANI et al., 2005). A fosforilação do domínio regulatório $\$ 473$ é também requerida para ativação completa de Akt1 (BROGNARD et al., 2001; TSURUTANI et al., 2005). PDK2 e ILK (do inglês protein kinase integrin-linked kinase) parecem ser as proteínas responsáveis pela ativação desse resíduo serina de Akt (CLARK et al., 2002; HAY, 2005; JENSEN, HUNTER, 2001; VARA et al., 2004). Akt2 é ativado nos resíduos serina 474 e treonina 309 e Akt3 nos aminoácidos serina 472 e treonina 305 (ARBOLETA et al., 2003). 
pAkt $\beta$ libera-se da superfície interna da membrana plasmática e passa a localizar-se no núcleo dentro 20 a 30 minutos após sua ativação por fatores de crescimento, indicando que alguns alvos da proteína Akt, que controlam a progressão do ciclo celular e apoptose estão localizados no núcleo, porém sua completo papel nuclear permanece desconhecido (ANDJELKOVIC et al., 1997; DAVID et al., 2004; JENSEN; HUNTER, 2001; KANDEL; HAY, 1999; MEIER et al., 1997). Feng et al. (2004) sugerem, que após ser ativado, PKB migra para o núcleo e posteriormente fosforila MDM2 no compartimento nuclear. As proteínas Akt1 e Akt2 parecem ter similares substratos in vivo, entretanto, as funções fisiológicas podem não ser as mesmas, uma vez que os níveis de ativação e especificidade celular são diferentes (ARBOLEDA et al., 2003).

A proteína Akt possui pouco ou nenhum efeito sobre p53, o que equivale dizer que p53 não serve como um substrato direto para a proteína Akt (FENG et al., 2004). Akt ativado fosforila, entretanto, Mdm2, uma ubiquitina ligase, nos aminoácidos serina 166 e serina 186, produzindo um aumento em sua localização nuclear, dessa forma, aumentando a degradação de p53, através de sua exportação para o citoplasma (MAYO et al., 2002; OGAWARA et al., 2002; VARA et al., 2004; VESTEY et al., 2005). Milne et al. (2004) relataram que a serina 188 é o principal sítio de fosforilação de MDM2 pela proteína Akt. Feng et al. (2004) e Kohn e Pommier (2005) afirmam que a fosforilação de MDM2 pela proteína Akt inibe a própria ubiquitinização de MDM2, por protegê-la de degradação dependente de proteossomo. Ogawara et al. (2002) acrescentam que a fosforilação de Mdm2, no aminoácido serina 186, afeta sua ligação à proteína p19 ${ }^{\mathrm{ARF}}$, a qual é capaz de seqüestrar Mdm2 ligada a p53. 
Na via do Wint, GSK3 (do inglês glycogen synthase kinase-3) fosforila axin, APC (do inglês adenomatous polyposis coli) e $\beta$-catenina, promovendo a interação de $\beta$-catenina com $\beta$-TrCP (do inglês $\beta$-transduction repeat containing protein), possibilitando, assim a ubiquitinização de $\beta$-catenina e sua posterior degradação pelo proteossomo. A proteína GSK-3 é fosforilada e inibida por pAkt, o que permite a translocação nuclear da molécula $\beta$-catenina, onde esta proteína associa-se com o fator de transcrição TCF/LEF-1 (do inglês T cell factor/lymphocyte enhancer binding factor-1), e propicia a transcrição da proteína ciclina D1 que, por sua vez, hiperfosforila a proteína $\mathrm{Rb}$, de modo a estimular a progressão do ciclo celular (GRILLE, 2003; JENSEN; HUNTER, 2001).

GSK3 também fosforila ciclina D1 e Myc, duas proteínas que promovem a entrada na fase S. Uma vez fosforiladas, por GSK3, ciclina D1 e Myc são translocadas do núcleo para o citoplasma, e posteriormente degradadas. Assim, inativação de GSK3ß por pAkt também eleva os níveis de ciclina $\mathrm{D} 1$, por permitir seu acúmulo no núcleo. Ativação de NFkB, um fator de transcrição, por Akt também estimula transcrição de ciclina D1 (NAVOLANIC et al., 2003).

Oren et al. (2002) relataram que beta-catenina pode inativar MDM2, além de permitir acúmulo de p53. Por outro lado, p53 pode promover a degradação de betacatenina.

As proteínas P21 $1^{\text {Cip/WAF1 }}$ e P27 Cip/WAF1 são membros da família Cip/Kip que podem inativar tanto as quinases dependentes de ciclina (CDKs- do inglês cyclindependent kinases) como as ciclinas, quando estímulos, como perda de adesão celular à matriz extracelular, dano no DNA, hipóxia e ativação de TGF- $\beta$ (do inglês transforming growth factor- $\beta$ ), estiverem presentes. A expressão de P21 Cip/WAF1 é induzida pela proteína p53 selvagem (SINGHAL et al., 2005; VIGLIETTO; MOTTI; 
FUSCO, 2002). A atividade inibitória de p $21^{\text {Cip/WAF1 }}$ está fortemente relacionada com sua localização nuclear (WEST; CASTILO; DENNIS, 2002). A proteína pAkt fosforila a proteína p21, no aminoácido treonina 145, inibe sua atividade antiproliferativa, por retê-la no citoplasma, através da ligação a proteína 14-3-3. Um mecanismo similar tem sido descrito para a proteína inibitória p27 (GRILLE et al., 2003; NAVOLANIC et al., 2003; VARA et al., 2004; WEST; CASTILO; DENNIS, 2002). Blagosklonny (2002) acrescenta que, uma vez no citoplasma, a proteína p27 teria a função de bloquear a ativação de caspase 2 e a proteína p21 poderia bloquear caspase 3 . Esses bloqueios contribuem para o bloqueio da apoptose.

A proteína Bad localiza-se no citoplasma e sob estímulo de IL-3, por exemplo, se fixa e inativa, em nível mitocondrial por heterodimerização, membros antiapoptóticos da família Bcl-2 como Bcl-xL (DATTA et al., 1997; YANG et al., 1995). A fosforilação de Bad tanto nos resíduos serina 112 (via EGFR/Ras-Raf-MEK-MAPK) como em serina 136 (via EGFR/PI3K-Akt) impede sua ligação, em nível mitocondrial, às proteínas $\mathrm{Bcl}-\mathrm{x}_{\mathrm{L}}$, por ligação à proteína 14-3-3 chaperone, prevenindo a liberação do citocromo c da mitocôndria (ADAMS; CORY, 1998; BROGNARD et al., 2001; DATTA et al., 1997; DEL PESO et al., 1997; FENG et al., 2004; GRILLE et al., 2003; KANDEL; HAY, 1999; MAYO; DONNER, 2002; SHE et al., 2005; VARA et al., 2004; WEST; CASTILO; DENNIS, 2002).

A caspase-9, que ativa caspase 3, desencadeando uma cascata de eventos moleculares que culminam com a apoptose, também é fosforilada e inativada por pAkt. Este, entretanto, não é o principal mecanismo de bloqueio da apoptose, em função do pAkt não ser capaz de bloquear a apoptose eficazmente após o citocromo c ser liberado (CARDONE et al., 1998; FENG et al., 2004; KANDEL; HAY, 1999; VARA et al., 2004). 
Ainda em relação à interação de pAkt com as caspases, convém mencionar que baixa expressão de pAkt resulta em diminuição dos níveis da proteína FLIP (do inglês FLICE-inhibitory protein), que compete com a proteína pró-caspase 8 pela ligação à proteína FADD (do inglês Fas-associated protein with death domain), ligação esta necessária para a geração de caspase 8 (PUDUVALLI et al., 2005; THONNBERRY; LASEBNIK, 1998).

pAkt regula negativamente a atividade do fator de transcrição FkHRL1 da família forkhead. pAkt, ao fosforilar FKHRL1, provoca sua retenção citoplasmática por interações com proteínas 14-3-3, desse modo impedindo sua ação apoptótica, uma vez que FKHRL1 regula a transcrição do gene pró-apoptótico Fas-Ligant (BROGNARD et al., 2001; BRUNET et al., 1999; GRILLE et al., 2003).

A ativação de NFKB é executada através da ativação da quinase (IKKa) ou CREB, que liberam NF-kB do seu inibidor (IKB), permitindo, assim, a atividade transcricional de p65 Rel, uma subunidade de NFKB (KANDEL; HAY, 1999; MAYO; DONNER, 2002; VARA et al., 2004; WEST; CASTILO; DENNIS, 2002). Shah et al. (2005) acrescentam que pAkt ativa a transcrição do fator nuclear kB permitindo a transcrição de genes com atividade antiapoptótica e pró-inflamatória.

Alguns dos efeitos de proliferação da via PI3K/Akt são mediados pela cascata TSC1/TSC2/mTOR/ p70 s6k . Mutações nos genes que codificam TSC1 e TSC2 estão associadas a desordens genéticas, denominadas de TSC (do inglês tuberous sclerosis), que são caracterizadas pelo desenvolvimento de hamartomas. Desse modo, TSC1 e TSC2 são considerados supressores tumorais (HAY, 2005; KANDEL; HAY, 1999; WEST; CASTILO; DENNIS, 2002).

A proteína pAkt estimula o crescimento, por fosforilar TSC2, inibindo a formação do complexo TSC1:TSC2. Este complexo possui atividade GTPase e atua 
inibindo atividade de Rheb, uma pequena GTPase requerida para ativação de mTOR (do inglês mammalian Target Of Rapamycin). Além disso, TSC2 é diretamente fosforilada e ativada pela quinase AMPK e Akt bloqueia a atividade desta quinase. Uma vez ativado, mTOR, forma um complexo sensível à rapamicina com Raptor (do inglês regulatory-associated protein of mTOR) e ativa a proteína quinase $p 70^{s 6 k}$ que promove crescimento celular. A proteína mTOR também promove a dissociação de 4E-BP de seu inibidor elF4E. A proteína 4E-BP possui a função de promover a transcrição de algumas proteínas (HAY, 2005; KANDEL; HAY, 1999; WEST; CASTILO; DENNIS, 2002).

Por controlar a síntese protéica, tanto de $\mathrm{p} 70^{\mathrm{s} 6 \mathrm{k}}$ como de 4E-BP1, a proteína pAkt estimula o crescimento celular e hipertrofia. Han, Khuri e Roman (2006) mostraram que a proteína fibronectina participa do carcinogênese de carcinomas de pequenas células do pulmão estimulando Akt, que por sua vez ativa a proteína mTOR.

Inibição da atividade de pAkt pode ser realizada por fosfatases, como a proteína PTEN (do inglês phosphatase and tensin homologue), também chamada de MMAC1 (do inglês mutated in multiple advances cancers), que remove fósforo, na posição 3' de PIP3, levando-o a PIP2. Este papel é desempenhado também por outra fosfatase denominada SHIP (do inglês SH2-containing inositol phosphatase) (CLARK et al., 2002; HAY, 2005; KANDEL; HAY, 1999; VARA et al., 2004; WEST; CASTILO; DENNIS, 2002).

SHIP desfosforila PIP3 na posição 5' e seu efeito parece restrito às células hematopoiéticas (BROGNARD et al., 2001). Leslie e Downes (2002) relataram, em seu estudo de revisão, que SHIP não interfere com os níveis basais de PIP3, uma vez que camundongos que perdem a atividade de SHIP conseguem se desenvolver. 
Isto sugere que SHIP regula somente a magnitude e duração da ação deste lipídio. Brognard et al. (2001) relataram que a fosfatase mais provavelmente envolvida na regulação da atividade de pAkt em células de carcinomas de pulmão é a proteína PP2, a qual regula a função de Akt pela direta desfosforilação de S473 e T308.

2.2.1 Relação da proteína Akt com as neoplasias malignas, com a sobrevida e com resistência às drogas antineoplásicas

A Atividade de Akt é comumente desregulada em uma variedade de neoplasias humanas em função da inativação da fosfatase PTEN, localizada no cromossomo 10, que regula negativamente os níveis de Akt ativado (LEE et al., 2005; TANG et al., 2005).

Vários trabalhos comprovam a participação da proteína Akt na carcinogênese do pulmão (BLACKHALL et al., 2003; BROGNARD et al., 2001; DAVID et al., 2004; SHAH et al., 2005; TSURUTANI et al., 2006). Nessa linha de investigação, convém mencionar o estudo de Tsurutani et al. (2006) onde pesquisaram a relação da proteína Akt1 fosforilada como fator prognóstico em adenocarcinoma e em carcinomas de células escamosas de pulmão (NSCLC-do inglês Non-Small Cell Lung Cancer Cells), através de imunoistoquímica e immunoblotting. Os resultados mostraram que ativação de pAkt, em ambos os resíduos S473 e T308, é um fator relacionado a um pobre prognóstico em todos os estádios das neoplasias investigadas. 
Resultado semelhante foi obtido por Tang et al. (2005), ao compararem, através de imunoistoquímica, a expressão de pAkt e PTEN com os dados clínicos de 102 pacientes com NSCL. Os autores observaram que a sobre-expressão de $p$-Akt e a perda da expressão da proteína PTEN estão correlacionadas a uma pobre diferenciação, envolvimento de linfonodos, metástases à distância e estadiamentos adiantados. Finalmente, os autores mostraram que pacientes com expressão positiva de pAkt e negativa de PTEN apresentam padrões de sobrevida piores do que aqueles que apresentaram expressão negativa de pAkt e positiva de PTEN.

Ainda sob a luz desse tema, Brognard et al. (2001) avaliaram o papel da proteína Akt1, Akt2 e Akt3 na aquisição de resistência a quimioterápicos e à irradiação em linhagens de células de NSCLC. Os autores observaram, através de immunoblotting, RT-PCR e de citometria de fluxo, um aumento de apoptose, após utilização de quimioterápicos e de irradiação, associada à inativação da proteína Akt por duas substâncias inibidoras de PI3K (LY294002 e Wortmannin).

A localização nuclear do pAkt foi associada com metástase nodal em uma pesquisa conduzida por Shah et al. (2005). Nesse estudo, os autores examinaram 82 amostras congeladas e emblocadas em parafina de NSCLC e a análise foi realizada através de western blot e imunoistoquímica. Shah et al. (2005), entretanto, não conseguiram estabelecer relação de pAkt com a sobrevida nesses pacientes.

Outro estudo relacionando carcinomas de pulmão com o papel de pAkt (fosforilado no resíduo serina 473) na sobrevida foi conduzido por David et al. (2004). Esses pesquisadores acompanharam 61 pacientes com NSCLC, durante 10 anos ou até a morte, e investigaram, através de imunoistoquímica, as proteínas pAkt, p53 e Ki67. Os autores concluíram que pAkt é um independente fator de pobre prognóstico. 
Blackhall et al. (2003) verificaram a relação da expressão da proteína Akt (contra ser 473) e do seu receptor tirosinoquinase denominado kit com os dados clínicos e como fator prognóstico em SCLC (do inglês small cell lung cancer), através de imunoistoquímica. Os autores concluíram que a proteína pAkt e o receptor Kit são expressos em altos níveis em SCLC, porém, somente houve associação estatisticamente significante, em relação à sobrevida, nos 42 pacientes examinados, com o receptor tirosinoquinase examinado.

Inúmeros estudos também relacionaram a participação da proteína Akt em carcinomas de próstata. Hu et al. (2005) ao pesquisarem a relação das caspases com a proteína pAkt (serina 473), avaliada através do método ELISA e western blot, em linhagens celulares de carcinomas de próstata, sob ação da substância MSeA (do inglês methylseleninic acid), concluíram que esta substância promove um efeito apoptótico nas células neoplásicas através do bloqueio da via PI3K/Akt. Os autores inferiram que a supressão da atividade da proteína pAkt pelo metilselenol provoca apoptose tanto pela via intrínseca como pela via extrínseca de ativação das caspases.

A perda da expressão da proteína PTEN e níveis altos de Akt fosforilado (Serina 473) foram demonstrados por Malik et al. (2002), através de imunoistoquímica, em 74 carcinomas de próstata analisados. Esses pesquisadores observaram que $92 \%$ dos adenocarcinomas pobremente diferenciados apresentaram-se fortemente marcados, em nível de membrana plasmática, para a proteína pAkt, concluindo que a progressão do carcinoma de próstata é acompanhada pelo aumento dos níveis da proteína Akt fosforilada. Finalmente, esses pesquisadores relataram que a proteína fosforilada Akt e a proteína fosforilada 
Bad encontravam-se imunomarcadas nessas neoplasias sugerindo que um dos alvos, para prevenir apoptose em carcinomas de próstata, é a proteína Bad.

Nakatani et al. (1999) investigaram a associação dos níveis da proteína Akt1, Akt2 e Akt3 em linhagens celulares de carcinomas de próstata sensíveis e insensíveis ao hormônio andrógeno, e em linhagens de carcinomas de mama sensíveis e insensíveis ao hormônio estrogênio, através de RT-PCR, western blot e northern blots. Os autores concluíram que a quantidade de Akt3 foi aproximadamente de 20 a 60 vezes maior nos carcinomas de mama e próstata insensíveis aos hormônios do que em neoplasias de mama e próstata sensíveis. Os níveis de Akt1 e Akt2 não mostraram diferenças nessas linhagens celulares estudadas. Os pesquisadores afirmaram que Akt3 pode contribuir para um fenótipo clínico mais agressivo dos carcinomas de mama e próstata que são insensíveis aos hormônios.

Um grande número de pesquisas descritas na literatura mostra a participação da proteína Akt na carcinogênese de mama (CLARK et al., 2002; PANIGRAHI et al., 2004; SCHMITZ et al., 2006; VESTEY et al., 2005; ZHANG et al., 2005). Zhou et al. (2001) ao utilizarem, em cultura de células neoplásicas de mama, agentes que ocasionavam danos ao DNA (etoposide e doxorubicin), observaram que a linhagem de células que apresentava um gene Akt mutante, o qual produzia uma proteína Akt não funcional, sofria mais apoptose e, portanto, maior redução do crescimento, do que as células que não apresentavam a referida mutação. Neste mesmo estudo, os autores, após inocularem as células neoplásicas em camundongos e gerar neoplasias em mama, observaram que somente aquelas neoplasias que apresentavam a via do Akt inativada eram sensíveis ao quimioterápico testado (ectoposide). Os autores atestaram, ainda, que a sensibilidade ao quimioterápico 
aplicado nos camundongos ocorreu em função do aumento da apoptose sofrida pelas células que apresentavam a via do Akt bloqueada.

Para avaliar o papel da via PI3K/Akt na sobrevida e na resistência a quimioterápicos em carcinomas de mama, Clark et al. (2002) analisaram, através de western blot e de citometria de fluxo, seis linhagens celulares de carcinomas de mama, com graus variados de atividade de receptores erbB2 e de receptores de estrógenos. Foi avaliada a atividade de pAkt na presença dos quimioterápicos Trastuzumab, Doxorubicina e de Tamoxifeno, assim como na presença de LY294002, um conhecido inibidor de ativação de Akt. Os resultados mostraram que a ação de Akt é responsável por aumentar a sobrevida e promover a resistência aos quimioterápicos testados nas linhagens celulares de carcinomas de mama avaliadas.

Schmitz et al. (2006) pesquisaram, através de imunoistoquímica em 121 casos de carcinomas de mama, a relação da expressão da proteína MDM2 fosforilada em serina 166 com a ativação de Akt (serina 473) para determinar a relevância de pMDM2 como fator prognóstico em carcinomas de mama nódulonegativos. Os pesquisadores encontraram resultados estatisticamente significantes na associação de neoplasias com prognósticos desfavoráveis que apresentavam o imunofenótipo pMDM2+/pAkt+.

Outro estudo, conduzido por Panigrahi et al. (2004) não encontrou associação da sobrevida com a imunoexpressão de PTEN (670 casos) e Akt (serina 473), em 691 carcinomas de mama analisados através imunoistoquímica. Vestey et al. (2005) analisaram a expressão imunoistoquímica das três isoformas de pAkt em 97 pacientes, juntamente com a expressão de p53/Hdm2. Os resultados mostraram que pAkt não se correlacionou com a expressão do receptor HER-2, porém correlacionou-se com o aumento citoplasmático de p53. A expressão da proteína 
pAkt também se associou com reduzida sobrevida. Nesse contexto, Vestey et al. (2005) inferiram que os níveis de expressão da proteína pAkt está relacionado com o desenvolvimento de carcinomas ductais de mama através de inativação de p53.

Kanamori et al. (2001) confirmaram, através de imunoistoquímica e western blot, a inversa correlação da proteína PTEN com a via PI3K/Akt (serina 473) em carcinomas do endométrio. O estudo foi realizado em 103 pacientes. A pesquisa sugeriu, também, que a proteína Bad pode ser um dos alvos da proteína pAkt, uma vez que a expressão da proteína Bad fosforilada foi maior nos casos que não apresentaram imunomarcação para a proteína PTEN.

Outro estudo em carcinoma de endométrio foi conduzido por Terakawa, Kanamori e Yoshida (2003). Os autores investigaram, através de imunoistoquímica (cortes em parafina) e de western blot (amostras congeladas), a relação da expressão da proteína PTEN e da proteína pAkt com a sobrevida, em 98 pacientes com carcinoma do endométrio em estádios avançados. Os resultados mostraram que perda da expressão de PTEN e posterior fosforilação de Akt é um fator prognóstico desfavorável em carcinomas de endométrio.

A atividade da proteína pAkt no prognóstico de carcinomas de ovário, também, está amplamente divulgada na literatura. Delord et al. (2005) mostraram que a quimioterapia com Trastuzumab, a qual atinge receptores HER2, pode promover a cura, em estádios precoces da doença, através da inibição da atividade da proteína pAkt. O estudo foi realizado em modelos utilizando camundongos com micrometástases de carcinoma de ovário e em culturas de células de carcinomas de ovário. A análise foi realizada através de citometria de fluxo, western blot e imunoistoquímica. 
Outra pesquisa conduzida por Arboleda et al. (2003) ratificou a participação da proteína pAkt2 no comportamento dos carcinomas de ovário. Esses autores transfectaram cDNA da proteína Akt2 em cultura de células de carcinomas de ovário e observaram aumento da capacidade da adesão, motilidade e invasão das células que sofreram trasnfecção.

A participação da proteína pAkt como bloqueadora da atividade apoptótica celular está bem firmada na literatura. Nesse sentido, convém mencionar a pesquisa de Hah et al. (2003) na qual após estudo em células de leucemia mielóide, tratadas com PMA (do inglês Phorbol 12-myristate 13-acetate), sugeriram que a resistência a apoptose induzida pela proteína PMA, nessas linhagens celulares neoplásicas, está relacionada a defeitos na ativação de caspase 3 , supressão da liberação do citocromo c e a persistente ativação da proteína pAkt.

Ao analisar a ação da substância indutora de apoptose TRAIL/Apo2L em linhagens de células de gliomas, através de citometria de fluxo e western blot, Puduvalli et al. (2005) demonstraram que esse produto induziu clivagem da proteína Akt1, desse modo, neutralizando os efeitos anti-apoptóticos de pAkt1.

Chadha et al. (2006) comprovaram que a proteína Akt fosforilada possui implicações prognosticas em carcinomas pancreáticos, após analisarem 39 casos através de estudo imunoistoquímico. Altos níveis da proteína Akt fosforilada, inesperadamente, foram associados a um melhor prognóstico.

O significado prognóstico da expressão de pAkt (serina 473) em melanomas foi avaliado por Daí, Marinka e Gang (2005). Utilizando microarray e imunoistoquímica, esses autores inferiram que a expressão de pAkt pode servir como um marcador independe de prognóstico em melanomas. 
Finalmente, alguns estudos têm sido conduzidos mostrando a ação da proteína pAkt em carcinomas localizados na região de cabeça e pescoço. Nessa linha de abordagem, um estudo conduzido por Gupta et al. (2002) sugeriu a participação do receptor EGF e da ativação da via PI3K/Akt (serina 473) na radioresistência e no controle local de carcinomas de cabeça e pescoço. Os autores relataram que a fosforilação de Akt, via PI3K, pode ser usada como um marcador prognóstico para resposta a radioterapia. Nessa pesquisa, foram avaliados 38 carcinomas epidermóides em relação a imunomarcação de pAkt e EGFR e os resultados foram relacionados com os dados clínicos.

Lim et al. (2005) conduziram um estudo para investigar a associação entre a expressão de pAkt e fatores clínicos e histopatológicos para verificar se pAkt poderia ser utilizado como marcador prognóstico em carcinomas epidermóides bucais. Os pesquisadores analisaram imunoistoquimicamente a expressão de pAkt em 84 casos de carcinomas epidermóides de boca. 0 estudo revelou que ativação de pAkt é um significativo indicador prognóstico.

\subsection{NF-KB}

O fator nuclear $\mathrm{kB}$ (NF-kB) foi descoberto por Baltimore e colaboradores em 1986 como um fator de transcrição no núcleo de células B, relacionando-se com o aumento da produção da cadeia kappa de imunoglobulina (AGGARWAL, 2004). NFKB compreende um conjunto de fatores de transcrição envolvido na promoção da expressão de mais de 150 genes envolvidos em uma ampla variedade de processos 
biológicos: resposta imune, inflamação, reabsorção óssea, oncogenêse, diabetes, doenças do coração e doença de Alzheimer.

Dentre os genes regulados por NF-kB estão aqueles que codificam citocinas inflamatórias, moléculas de adesão, cicloxigenase sintetase e óxido nítrico sintetase. NF-KB não é encontrada constitutivamente ativa em células normais, exceto em células T proliferantes, células B, monócitos e astrócitos (AGGARWAL, 2004; CAO; KARIN, 2003; KUMAR et al., 2004; MOYNAGH, 2005; PERKINS, 2004; SAKURAI et al., 1999; YAMAMOTTO; GAYNOR, 2004).

A família NF-kB é composta de cinco genes: p50, p52, c-Rel, RelB e RelA (p65). As proteínas NF-kB são conservadas de Drosophila melanogaster a humanos e relacionadas através de um domínio $\mathrm{N}$-terminal, chamado $\mathrm{RH}$ (do inglês rel homology). O domínio RH medeia suas dimerizações, interação com inibidores específicos, translocação para o núcleo e ligação ao DNA (AGGARWAL, 2004; CAO; KARIN, 2003; DOLCET et al., 2005; KUMAR et al., 2004; LI; STARK, 2002; MOYNAGH, 2005; SUH; RABSON, 2004;YAMAMOTO; GAYNOR, 2004; ZHOU et al., 2005a).

A família de proteínas NF-KB consiste de cinco proteínas estruturalmente relacionadas e funcionalmente conservadas: RelA (p65), RelB, c-Rel, NF-kB1 (p50/p105) e NF-kB2 (p52/p100) (CAO; KARIN, 2003; SUH; RABSON, 2004; ZHOU et al., 2005a). As proteínas NF-KB podem ser agrupadas em dois grandes grupos: o primeiro grupo composto pelas proteínas p105 e p100. Ambos possuem um domínio C-terminal que contem múltiplas cópias repetidas de anquirinas, o qual atua reprimindo a atividade dessas moléculas. Membros desse grupo não funcionam como fatores de transcrição, sendo sintetizados na forma de precursores inativos (CAO; KARIN, 2003; LI; STARK, 2002; SUH; RABSON, 2004). Quando os 
segmentos contendo anquirinas são alvo de proteólise, dependente de ubiquitinização no proteossomo, ocorre a remoção do domínio C-terminal e a transformação da proteína p105 em p50 e da proteína p100 em p52, gerando proteínas maduras, o que equivale dizer com capacidade transcricional (AGGARWAL, 2004; CAO; KARIN, 2003; DOLCET et al., 2005; HACKER; KARIN, 2002; MOYNAGH, 2005; PERKINS, 2004; RAVI; BEDI, 2004; YAMAMOTO; GAYNOR, 2004).

O segundo grupo de proteínas NF-kB inclui p65 (RelA), Rel (c-Rel), RelB. As proteínas do segundo grupo NF-kB, diferente das proteínas do primeiro grupo, além do domínio $\mathrm{RH}$, possuem um ou mais domínios TAD (do inglês transcricional activation domains) na região $C$ terminal. Os domínios TAD promovem transcrição por facilitar o recrutamento de co-ativadores e deslocamento de repressores (HACKER; KARIN, 2002; HAYDEN; GHOSH, 2004; LI; STARK, 2002; MOYNAGH, 2005; YAMAMOTO; GAYNOR, 2004).

As proteínas da família NF-KB formam homo e heterodímeros, nos quais as formas ativas mais comuns são p50/RelA ou p52/RelA. Outros exemplos de homo e heterodímeros possíveis incluem: proteína p65/p50, RelB/p100, p52/p50, c-Rel com p50 e p65, p65/p65, p65/p50, p65/p52, p52/c-Rel, p50/c-Rel, p65/c-rel, RelB/p50, RelB/p52, c-rel/c-rel (HAYDEN; GHOSH, 2004; LI; STARK, 2002).

Convencionou-se chamar as formas p105/p50 de NF-kB1 e a apresentação sob a forma p52/p100 de NF-kB2 (AGGARWAL, 2004; HAYDEN; GHOSH, 2004; MOYNAGH, 2005; RAVI; BEDI, 2004). NF-KB foi originalmente relacionado ao heterodímero p50-p65 (CAO; KARIN, 2003; KUMAR et al., 2004; LI; STARK, 2002; MOYNAGH, 2005). A forma mais abundante intracelular de NFKB encontrada sob a forma do heterodímero p50/p65 (ZHOU et al., 2005b). 
Em células não estimuladas, as proteínas da família NF-KB existem como heterodímeros ou homodímeros seqüestradas no citoplasma em função da associação não covalente com membros a família de proteínas inibitórias IkB (DOLCET et al., 2005; KUMAR et al., 2004; LI; STARK, 2002; MOYNAGH, 2005; SCHUCHMANN; GALLE; 2002; YAMAMOTO; GAYNOR, 2004). As proteínas que compõem a família dos fatores de transcrição NF-kB são ativadas por uma grande variedade de estímulos dentre os quais incluem: danos ao DNA, citocinas, estresse físico e radicais livres. Tais estímulos permitem a translocação de NF-kB usualmente dentro de 15 minutos (PAPOULI; DEFAIS; LARMINAT, 2002).

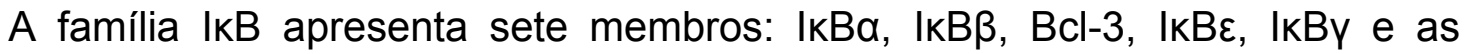
proteínas precursoras NF-kB1/p105 NF-kB2/p100 que possuem de cinco a sete anquirinas nos domínios C-terminal que se ligam ao domínio RH das proteínas NF$\mathrm{KB}$, retendo, dessa maneira, a proteína NF-KB no citoplasma (AGGARWAL, 2004; CAO; KARIN, 2003; DOLCET et al., 2005; HACKER; KARIN, 2002; HAYDEN; GHOSH 2004; MOYNAGH, 2005; RAVI; BEDI, 2004; YAMAMOTO; GAYNOR, 2004).

IKBa liga-se ao dímero p65/p50 mascarando somente a seqüência de localização nuclear (NSL) de p65, permanecendo a seqüência de localização nuclear de p50 acessível. A presença acessível tanto de NSL em p50 como da seqüência de exportação nuclear em IkBa, permite uma constante movimentação do complexo IkBa/NF-kB entre o núcleo e o citoplasma, embora a localização predominante seja citoplasmática (HAYDEN; GHOSH 2004; SUH; RABSON, 2004; YAMAMOTO; GAYNOR, 2004).

Moynagh (2005), entretanto, relata que o complexo NF-kB-IkBß não realiza movimentação nuclear, porque IkBß pode mascarar NSL. IKBE parece regular o 
homodímero p65 e o heterodímero cRel:p65. IKBع possui habilidade de se deslocar

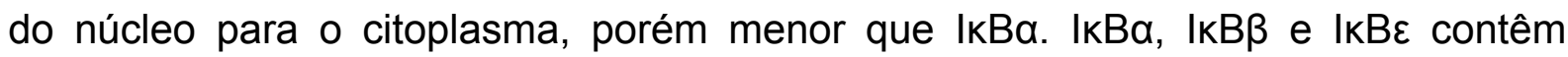
domínios regulatórios do tipo N-terminal que são importantes para degradação das proteínas IkB (HAYDEN; GHOSH 2004; SUH; RABSON, 2004).

O papel desenvolvido por outras proteínas da família IkB, como da proteína IkBל, não foi ainda completamente demonstrado, já a proteína BCL-3 possui localização predominantemente nuclear e forma complexos com os homodímeros p52 e p50 (DOLCET et al., 2005; MOYNAGH, 2005; SUH; RABSON, 2004).

IkBa também regula a atividade NF-KB ao entrar no núcleo onde se liga a subunidade p65 e a conduz para o citoplasma, desse modo reduzindo os níveis de p65 no núcleo e a atividade de NF-kB (MOYNAGH, 2005).

Sinais extracelulares, incluindo citocinas (TNFa e IL-1), CD40 ligand (CD40L), bactérias (lipopolissacárides-LPS), vírus e agentes que promovam estresse, permitem a ativação de quinases inibidoras de IKB (IKK), que são capazes de fosforilar dois resíduos específicos de serina (Ser 32 e Ser36) de IkBa e resíduos Ser19 e Ser23 em IkBß. Uma vez fosforiladas as proteínas IkB são reconhecidas por um complexo de ubiquitina ligase SCF contendo $\beta$-TrCP ou complexo $E 3^{\mathrm{IKB}}$ ubiquitina ligase, permitindo suas ubiquitinizações e degradação no proteossomo 26 (CAO; KARIN, 2003; KUMAR et al., 2004; MOYNAGH, 2005; RAVI; BEDI, 2004; YAMAMOTO; GAYNOR, 2004). A destruição de IKB permite a translocação para o núcleo dos dímeros de NFK-B e sua posterior ligação ao promotor de genes alvos (CAO; KARIN, 2003; DOLCET et al., 2005; HAYDEN; GHOSH, 2004; LI; STARK, 2002; SCHUCHMANN; GALLE, 2002).

A proteína IKK é um complexo de 700 a 900 kDa composto de três subunidades: as subunidades catalíticas IKKa, também conhecida como IKK1 ou 
CHUK, a subunidade IKK $\beta$, também chamada de IKK2, e uma terceira subunidade, que possui ação reguladora, chamada de IKKY ou IKKAP1 ou NEMO (do inglês NFkB essential modifier). IKKY é necessária para conectar o complexo IKK aos ativadores upstream (CAO; KARIN, 2003; DOLCET et al., 2005; HAYDEN; GHOSH, 2004; KUMAR et al., 2004; PERKINS, 2004; RAVI; BEDI, 2004; SUH; RABSON, 2004; YAMAMOTO; GAYNOR, 2004). A região C-terminal da subunidade IKKy serve como um sítio de ligação de sinais que levam a ativação da proteína IKK e metade da região N-terminal liga-se a IKKß (RAVI; BEDI, 2004).

Ativação do complexo IKK envolve a fosforilação de dois resíduos serina localizados em IKKa (S176 e S180) ou de IKKß (S177 e S181). Duas teorias são sugeridas para ativação do complexo IKK. Um modelo sugere o recrutamento do complexo IKK ao receptor na membrana plasmática resultando em sua autofosforilação e subseqüente ativação. Enquanto o outro modelo de ativação relaciona-se com a participação de MAPK3 (do inglês mitogen-activated protein kinase kinase kinase) dentre elas MEKK1 (do inglês mitogen activated protein/ERK kinase kinase), MEKK2, MKK3, TAK1 (do inglês TGF- $\beta$ activating kinase 1 ), NIK (do inglês NFKB inducing kinase) e NAK (do inglês NFKB activating kinase) (RAVI; BEDI, 2004; SUH; RABSON, 2004; YAMAMOTO; GAYNOR, 2004). Outras kinases como Akt podem ativar o complexo IKK (SUH; RABSON, 2004).

A proteína NIK é capaz de fosforilar e ativar IKKa e IKK em resposta a ativação de receptores da família TNF. Tem sido exposto que a proteína MEKK3 fosforila IKKß in vitro e que essa proteína é indispensável para a montagem do complexo IKK-IKBa/NFkB, permitindo a ativação precoce de NF-kB (HAYDEN; GHOSH, 2004; KUMAR et al., 2004; LI; STARK, 2002; MOYNAGH, 2005). 
Outras proteínas citadas na literatura que podem funcionar como quinases de

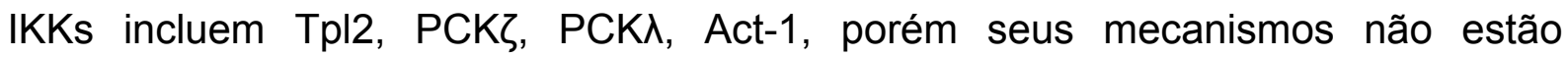
completamente elucidados. Embora não estejam definidos todos os modos de ativação de IKK, acredita-se que o complexo IKKa/ß/Y é indispensável para ativação de NF-kB (HAYDEN; GHOSH, 2004).

É oportuno mencionar o que a literatura denomina de via clássica ou canônica de ativação de NF-kB: dímeros contendo Rel-A ou c-Rel associado a p50 encontram-se inativos no citoplasma por estarem interagindo com as proteínas IKB, mais comumente IKBa. Esta via é disparada por citocinas pró-inflamatórias e infecções virais e bacterianas. Após a ativação, a subunidade IKKß é o maior responsável pela fosforilação de IKB. Após a fosforilação, proteínas IKB são reconhecidas por $\beta$-TrCP, uma subunidade do complexo de ubiquitinização ligase SCF (do inglês Skp-1/ Cul/F Box), e posteriormente sofrem ubiquitinização pelo proteossomo e NF-kB move-se para o núcleo onde atua como fator transcricional de mais de 180 genes que possuem a seqüência motif (GGGRNNYYCC) (CAO; KARIN, 2003; DOLCET et al., 2005; HACKER; KARIN, 2002; MOYNAGH, 2005; SUH; RABSON, 2004; ZHOU et al., 2005b).

Já a via alternativa é ativada por membros da família do fator de necrose tumoral, como BAFF (do inglês B cell activating factor), expressado em macrófagos, células dendríticas e células B e pelo ligante de CD40, encontrado em macrófagos, células dendríticas, células epiteliais, células B e T e finalmente por LT $\beta R$, presente em linfócitos T. Os dímeros contendo as subunidades RelB-p52 (precursor RelBp100) são os alvos principais. Nessa via NIK ativa IKKa que, então, pode fosforilar p100 que, por sua vez, sofre proteólise e transforma-se na forma p52 madura. Então os dímeros se movem para o núcleo, onde podem ativar específicos genes alvos 
(CAO; KARIN, 2003; DOLCET et al., 2005; HACKER; KARIN, 2002; MOYNAGH, 2005; RAVI; BEDI, 2004; SUH; RABSON, 2004; YAMAMOTO; GAYNOR, 2004).

Embora os dímeros que fazem parte da via clássica (RelA-p50, cRel-p50, RelB-p52) sejam os mais comumente produzidos, outros tipos de homodímeros (p50-p50 e p52-p52) e heterodímeros (c-Rel-RelA, c-Rel-c-Rel) também são produzidos e cada dímero de NFKB provavelmente possui uma função regulatória distinta (DOLCET et al., 2005). Ativação diferencial de subunidades de NFKB pode resultar em regulações distintas de genes, através de diferentes ligações com o DNA (PERKINS, 2004).

A proteína IkBa pode ser alvo de degradação, não só pelas proteínas IKKa e IKKß, como também pela proteína CK2 (do inglês casein kinase II), uma serinatreonina quinase que fosforila IKBa na região C-terminal, local distinto da fosforilação das IKKs que fosforilam na região N-terminal (RAVI; BEDI, 2004). Nesse sentido Suh e Rabson (2004) relataram, em seu estudo de revisão, que IkBa e IKBß apresentam um domínio C-terminal chamado de PEST (do inglês proline-glutamic acid, serine and threonine-rich) que está envolvido na fosforilação mediada por CK2.

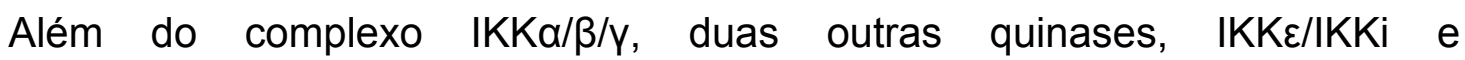
TBK1/NAK/T2K, foram associadas a ativação de NF-KB. A proteína IKKE/IKKi está envolvida na ativação de células T e a proteína TBK1/NAK/T2K pode estar envolvida na ativação de NF-KB em resposta a PDGF. As evidências na literatura indicam que a atuação dessas duas proteínas, na ativação NF-kB, ocorre independente e abaixo da cascata que leva a degradação de IKB (LI; STARK, 2002).

A atividade de NF-KB é também regulada através de modificações covalentes que recrutam co-ativadores e alteram a habilidade de ligação dos dímeros de NF-KB ao DNA. Estímulos dependentes de fosforilação de p65 foram os primeiros eventos 
reguladores reconhecidos após a degradação de IKB. Tanto p65 como c-Rel possuem um local no resíduo Ser 276 para interação com a proteína PKAc (do inglês c-AMP dependent protein kinase A) (MOYNAGH, 2005; RAVI; BEDI, 2004).

PKA encontra-se associado ao complexo NFKB-IKB no citoplasma e a degradação de IKB ativa PKA que posteriormente fosforila p65 no resíduo Ser 276. A fosforilação de p65 por PKA desempenha uma função dupla: aumenta a eficiência de ligação de p65 ao DNA e possibilita um local adicional de interação para o coativador transcricional CBP/p300. Acetilação de p65 por CBP/300 prolonga a ligação de NF-kB por prevenir interação com IkB. Este modelo exige que p65 seja desacetilada por HDAC-3, que interage diretamente com p65, antes da ligação com IKB e exportação para o citoplasma (HAYDEN; GHOSH, 2004; LI; STARK, 2002; RAVI; BEDI, 2004).

Quando a subunidade p65 não está fosforilada, a região C-terminal da proteína interage com o domínio Rel homólogo, desse modo, mascarando o sítio de ligação ao DNA, assim como a associação com CBP/p300. A fosforilação do resíduo Ser 276 previne esta associação intramolecular e facilita tanto a ligação ao DNA como a atividade transcricional de NF-kB (HAYDEN; GHOSH, 2004).

Outra proteína implicada na fosforilação de p65 é a quinase CKII (do inglês casein kinase II). A proteína IKB protege p65 da fosforilação por CKII, que está constitutivamente ativada, porém, sinais que conduzam a degradação de IKB expõem o local de fosforilação de p65 para CKII. Dessa maneira, pelo menos duas quinases (PKA e CKII) são capazes de fosforilar p65 em diferentes resíduos, aumentando atividade transcricional de NF-KB (LI; STARK, 2002; MOYNAGH, 2005).

As proteínas quinases MSK1/2 (do inglês mitogen and stress activated protein kinase) também fosforilam Ser 276 de p65 e estimulam atividade transcricional de 
NF-kB. A diferença em relação a PKA está na localização de MSK1/2 que é nuclear. (HAYDEN; GHOSH, 2004; RAVI; BEDI, 2004).

Respostas de NF-KB individuais dependem de uma onda de ativação e inativação de vários membros da família NF-kB, em função da seletividade dos complexos IKK para diferentes IKBs, assim como pelas diferentes regulações realizadas pela $\mathrm{I} \mathrm{kB}$ nos dímeros $\mathrm{NF}-\mathrm{kB}$. As vias mais estudadas relacionadas à ativação de NF-kB incluem os seguintes receptores: TNFR (receptor relacionado TNFa), EGFR, receptor do fator de crescimento de insulina, TLR/IL1/IL-18 (do inglês Toll-like receptors e Interleucina) e BCR, os dois últimos relacionados com a atuação na resposta imune (DOLCET et al., 2005; HAYDEN; GHOSH, 2004; MOYNAGH, 2005).

Uma vez estimulados esses receptores desencadeiam uma seqüência de sinais envolvendo a ativação das IKKs e posterior ubiquitinização do IKBa. A superfamília de receptores TNF pode mediar carcinogênese através da indução da proliferação, invasão e metástase de células tumorais, sendo o mais potente ativador de NF-kB consistindo de pelo menos 19 ligantes e 29 receptores e exibem uma grande diversidade tecidual. Através da ativação de NF-kB, sinalização via TNF regula diretamente a expressão de genes anti-apoptóticos: clAP1/2 e Bcl-XL (AGGARWAL, 2004; DOLCET et al., 2005; HAYDEN; GHOSH, 2004).

Ativação do complexo IKK mediada por TNFa tem sido extensamente investigada e envolve receptores TNF-R1. Sinalização relacionada aos receptores TNF requer adaptadores intracelulares para posterior ativação de NF-kB. Antes de agregar proteínas o receptor TNF, uma vez ativado, libera o seu domínio SODD (do inglês silencer of death domain), um inibidor endógenos da atividade de TNF. Após a 
liberação de SODD, a proteína TRADD (do inglês TNRF receptor-associated death domain protein) é associada ao receptor TNF (HAYDEN; GHOSH, 2004).

TRADD posteriormente recruta proteínas da família TRAF (do inglês TNF receptor associated factor) composta pelas proteínas TRAF2, TRAF3 e TRAF5. Alguns estudos têm demonstrado que TRAF2 recruta IKKa e IKKß após tratamento com TNFa. TRAF2 também interage com RIP1 (do inglês receptor interacting protein 1). RIP1 pode recrutar IKK ao unir-se à subunidade NEMO, de maneira independente de TRAF2, e após a ligação induzir auto-fosforilação de IKK (YAMAMOTO; GAYNOR, 2004). RIP1 é essencial para ativação de NF-kB induzida por TNFa, uma vez que recrutamento de IKK por TRAF2 na ausência de RIP1 não é suficiente para ativação de IKK. Por fim, é interessante mencionar que RIP1 pode ser recrutada diretamente por TRADD (HAYDEN; GHOSH, 2004; MOYNAGH, 2005).

NF-kB é também ativado via receptores EGF (EGFR). EGFR corresponde a uma família de receptores tirosino-quinase que incluem os seguintes componentes: EGFR (ErbB-1, HER), Neu (ErbB-2, HER2), ErbB-3 (HER3) e ErbB-4 (HER4). Expressão aumentada de membros da família EGFR ou HER2/neu tem sido observada em uma proporção de neoplasias humanas e está relacionada com proliferação, adesão, migração, angiogênese, maior número de metástases, resistência a apoptose e pobre prognóstico (AGGARWAL, 2004; CAO; KARIN, 2003; DOLCET et al., 2005; KUMAR et al., 2004; PERKINS, 2004; RAVI; BEDI, 2004). 


\subsubsection{NF-kB e regulação da apoptose}

Células neoplásicas, de quase todos os tecidos, podem adquirir a característica de manter a proteína NF-kB ativa indefinidamente, dada a sua habilidade de possibilitar transformação maligna, além de fornecer um mecanismo pelo qual tais células escapam do sistema imune e tornam-se resistentes a quimioterapia e radioterapia (BUTCHER et al., 2004; RAVI; BEDI, 2004).

Nessa linha de pensamento, convém mencionar que NF-kB pode regular a expressão de proteínas que regulam a apoptose. Uma dessas proteínas é a FLIP que se mostra semelhante a caspase 8 , porém perde sua atividade de protease e compete com essa caspase pelo DISC (Death-Inducing Signaling Complex), inviabilizando apoptose via Fas ligante. Em última análise, FLIP inibe a atividade apoptótica da caspase 8 (PUDUVALLI et al., 2005). Outras proteínas, induzidas por NF-KB, da cascata de sinalização de TNF- $\alpha$ são as proteínas TRAF2, TRAF1 e TRAF6 que neutralizam a ação apoptótica da caspase 8. Juntas, essas proteínas podem conferir resistência a apoptose (DOLCET et al., 2005; MOYNAGH, 2005; RAVI; BEDI, 2004; SCHUCHMANN; GALLE, 2002).

NF-kB pode, também, induzir a expressão de inibidores da apoptose (IAPsdo inglês Inhibitors of apoptosis) e de alguns membros da família anti-apoptótica Bcl2 (do inglês B-cell lymphocyte/leukemia-2). As proteínas clAp1, clAp2 e XIAP suprimem apoptose induzida através de inibição direta de caspases 3, 6 e 9 (do inglês cysteine aspartate proteases). NFKB pode, também, atenuar a expressão de proteínas pró-apoptóticas, como BAX (BUTCHER et al., 2004; DOLCET et al., 2005; 
PERKINS, 2004; RAVI; BEDI, 2004; SCHUCHMANN; GALLE, 2002; YAMAMOTO; GAYNOR, 2004).

Antagonismo das funções de transcrição que ocorre entre p53 e NF-kB envolve competição com co-ativadores como p300 e CBP (do inglês CREB-binding protein). Além disso, a proteína p53 reprime a expressão de Bcl-3, um co-ativador transcricional da subunidade p52 de NF-kB, desse modo alterando a forma ativadora p52/Bcl-3, para o complexo repressor p52/HDAC1. Finalmente, ativação de NF-kB mediada por IKK2 tem mostrado proteger células de apoptose induzida por dano no DNA, através do aumento dos níveis de MDM2 (DOLCET et al., 2005; PERKINS, 2004; RAVI; BEDI, 2004).

Células NK (do inglês natural killer) e CTLs (do inglês cytotoxic T lymphocytes) induzem apoptose de células neoplásicas através de dois mecanismos: a liberação de granzimas B que induzem clivagem e ativação de caspases $3,6,7,8,9$ e 10 e o segundo mecanismo envolve ligação dos receptores TNF de morte, como TRAIL-R1/R2 e CD45 nas células alvos por ligantes (FasL, Apo2L/TRAIL), expressos por células NK ou CTLs. Tais ligantes e receptores são produzidos por estímulo dependente de INF (do inglês interferon). NFKB reduz a morte celular induzida por células NK ou CTLs através da estimulação das proteínas antiapoptóticas c-FLIP, Bcl-xL e IAPS (HAYDEN; GHOSH, 2004; KIM et al., 2003; RAVI; BEDI, 2004; SUH; RABSON, 2004).

Convém relatar que a ativação prolongada de JNK/AP-1, via RTNFa, permite apoptose e indução de NFKB permite a síntese de certas proteínas que inibem a ativação de JNK/AP1. Um desses fatores ativados por NF-kB é a proteína GADD45 $\beta$ que inibe a via de ativação de JNK por bloquear a quinase MKK7. Outra proteína que inibe a ativação de JNK e que é induzida por NF-kB é a XIAP (do inglês X- 
chromosome-linked inhibitor of apoptosis). A proteína XIAP além de bloquear JNK, inibe também muitas caspases pró-apoptóticas (HAYDEN; GHOSH, 2004).

\subsubsection{Regulação da proliferação, angiogênese, invasão e metástase}

NF-kB promove progressão do ciclo celular por regular a expressão de vários genes envolvidos na maquinaria do ciclo celular como as ciclinas D1, D2, D3 e E, além de c-myc e c-mycb. Expressão de ciclina D1 induzida por NF-kB parece ser o elemento chave no desenvolvimento de glândulas mamárias e carcinogênese de mama (AGGARWAL, 2004; DOLCET et al., 2005; KUMAR et al., 2004; RAVI; BEDI, 2004; SUH; RABSON, 2004; YAMAMOTO; GAYNOR, 2004).

Convém acrescentar que NF-kB induz a expressão de moléculas de adesão, como ICAM-1 (do inglês intercellular adhesion molecule), E selectina, ELAM-1 e VCAM-1 (do inglês vascular cell adhesion molecule) e metaloproteinases, como MMP-2 e MMP-9, envolvidas na degradação das proteínas da matriz extracelular e metástase (AGGARWAL, 2004; DOLCET et al., 2005; PERKINS, 2004).

Alguns fatores angiogênicos incluindo VEGF (do inglês vascular endothelial grown factor), MCP-1, IL-8, TNF produzidos por macrófagos e neutrófilos são também dependentes da ativação de NF-kB, assim como regulação de genes relacionados à vasodilatação, como iNOS (do inglês inducible nitric oxide synthase) (AGGARWAL, 2004; DOLCET et al., 2005; PERKINS, 2004; SUH; RABSON, 2004; YAMAMOTO; GAYNOR, 2004). 
Alguns oncogenes medeiam seus efeitos através da interação com NF-kB, entre esses podemos citar os oncogenes Ras, c-myc e Pim-2 (AGGARWAL, 2004). Ao lado disso, algumas citocinas reguladas por NF-KB são fatores de crescimento para células neoplásicas: TNF é um fator de crescimento para linfomas de Hodgkin, linfoma de células T cutâneo e gliomas e IL-6 funciona como fator de crescimento para mieloma múltiplo. Além disso, EGF, um fator de crescimento para neoplasias de mama e próstata, medeia seus efeitos, em parte, através da ativação de NF-KB (AGGARWAL, 2004).

O óxido nítrico, que influencia na habilidade do tumor de metastatizar, possui expressão dependente de NF-KB (AGGARWAL, 2004). NF-KB induz a expressão de cicloxigenase-2 (COX2), cuja expressão é importante para o crescimento neoplásico, como observado em carcinomas de cólon, uma vez que COX-2 induz a expressão de alguns fatores angiogênicos (VEGF, FGF, PDGF, TGF- $\beta$ ) e de seus receptores na superfície das células endoteliais (DOLCET et al., 2005; PERKINS, 2004; RAVl; BEDI, 2004; YAMAMOTO; GAYNOR, 2004).

\subsubsection{NF-KB e neoplasias malignas}

Algumas oncoproteínas virais podem interagir com o complexo IKK e ocasionar ativação de NF-kB. O vírus Epstein Barr, implicado no linfoma de Burkitt e no linfoma de Hodgkin, é capaz de induzir persistente ativação de NF-kB: as proteínas EBNA-2 (do inglês EBV nuclear antigen-2) e LMP-1 (do inglês latent 
membrane protein-1) aumentam a atividade de transcrição de NF-kB (DOLCET et al., 2005; PERKINS, 2004).

Rearranjos ou deleções de cromossomos afetando o locus NF-kB2, no cromossomo 10q24, resultam da perda de anquirinas de p100 e geração de proteína p52 constitutivamente ativa. Essa condição tem sido observada em linfomas de células $\mathrm{T}$, linfomas de células B e mieloma múltiplo. Algumas leucemias linfocíticas de células B podem apresentar translocação t (14;19) (q32;q13). Esta translocação resulta no aumento da expressão de $\mathrm{Bcl}-3$ que atua como um co-ativador transcricional dos homodímeros p50 ou p52, permitindo um aumento da atividade de NF-kB e sobre-expressão de seus alvos como a ciclina D1 (DOLCET et al., 2005).

Mutações que conduzam a perda de função de em $\mathrm{lkBa}$, resultando em constitutiva atividade nuclear de NF-KB são características das células de ReedSternberg em linfomas de Hodgkin. Altos níveis de c-Rel têm sido encontrados em linfomas de células $B$, linfomas de Hodgkin e em linfomas de células B do mediastino (AGGARWAL, 2004). Sobre-expressão de c-Rel, também, foi observada em carcinomas de pulmão e mama, assim como altos níveis de proteínas de genes alvos de NF-kB: ciclina D1, c-myc eBcl-XL, IL-6, Bcl-2, VEGF, MMP9 e IL8 (DOLCET et al., 2005; SUH; RABSON, 2004; ZHOU et al., 2005b). 
2.3.4 Relação da proteína NF-KB com a sobrevida e com a resistência às drogas antineoplásicas

Para avaliar a relação da expressão dos níveis da subunidade p65 de NF-kB com o comportamento maligno e atividade antiapoptótica dos carcinomas epidermóides bucais, Nakayama et al. (2001) analisaram, através de imunoistoquímica, 36 carcinomas epidermóides bucais e 15 casos com displasia epitelial na cavidade bucal. Os autores inferiram que expressão elevada de p65 e IKKa contribuem para o comportamento maligno e para a atividade antiapoptótica, provavelmente via pAkt, em carcinomas epidermóides bucais.

Lee et al. (2005) analisaram a relação da ativação da proteína NF-kB e Akt com o prognóstico em 290 casos de carcinomas gástricos. Os autores utilizaram as seguintes ferramentas: imunoistoquímica, western blot e PCR. As linhagens celulares de carcinomas utilizadas continham Akt constitutivamente ativo ou o repressor de NF-kB, o IkBa, mutado. Os resultados indicaram que ativação de NFKB, correlacionada com ativação de Akt, estava associada a um pior prognóstico.

Zhou et al. (2005b) quantificaram, em linhagens celulares de carcinoma de mama e em carcinomas primários de mama, pelo método Elisa, a quantidade de p50 e p65 ligadas ao DNA, para avaliar a possibilidade da proteína NF-kB ativada participar da patogênese de carcinomas de mama que apresentavam o receptor de estrógeno (ER). Os resultados encontrados indicaram que a ligação de p50 ao DNA, em carcinomas ER positivo, correlacinou-se positivamente não só com a presença de carcinomas apresentando ER, como também com alguns aspectos clínicos, entre os quais, os seguintes: recidiva, metástase e tempo livre de doença. 
Em seus estudos revisionistas, Suh e Rabson (2004) referiram que as proteínas constitutivamente ativadas NIK, partícipes da via alternativa de ativação de NF-kB, participam da patogênese dos carcinomas de próstata.

Para avaliar se a localização de NF-kB em adenocarcinomas de próstata com diferentes estadiamentos histológicos, poderia ser utilizada como fator prognóstico, Lessard et al. (2003) analisaram, através de imunoistoquímica, a sublocalização da subunidade p65 de NFkB. Os autores concluíram que a localização nuclear de NFkB pode ser utilizada como fator prognóstico em adenocarcinoma de próstata.

Fradet et al. (2004) analisaram, através de imunoistoquímica, a relação da imunomarcação nuclear de NF-kB, com a recorrência de adenocarcinomas de próstata. Os autores inferiram que NF-kB pode servir como um marcador independente de risco de recorrência em adenocarcinomas de próstata.

Outro estudo realizado com a finalidade de verificar a utilização da proteína NF-kB, como fator prognóstico em adenocarcinomas de próstata, foi conduzido por Ross et al. (2004). A reação de imunoistoquímica foi a técnica utilizada. Os pesquisadores sugeriram, após análise dos resultados, que a proteína NF-kB pode ser utilizada como fator prognóstico e que estratégias com quimioterápicos que bloqueiem a atividade de NF-kB seriam úteis para evitar recidivas.

\subsection{Metalotioneína}

A Metalotioneína corresponde a uma superfamília de proteínas, com 61 aminoácidos em mamíferos, de baixo peso molecular (6000 Da), descoberta em 
1957, nos rins de cavalos, ricas em cisteína (1/3 dos aminoácidos presentes) e que possuem a característica de serem ligantes de metais bivalentes (ABDEL-MAGEED; AGRAWAL, 1998; CHERIAN; JAYASURYA; BAY, 2003; ROMERO-ISART; VASAK, 2002; SATO; KONDOH, 2002; THEOCHARIS et al., 2004). O nome metalotioneína reflete as altas concentrações de tiolato sulfúrico e metal, ambos na ordem de $10 \%$. MTs (metalotioneínas) não são encontradas somente no reino animal, mas também em microorganismos procariotas, assim como em plantas (HAQ; MAHONEY; KOROPATNICK, 2003; ROMERO-ISART; VASAK, 2002; VASAK; HASLER, 2000).

A proteína não ligada a metais é denominada de tioneína ou apoproteína, sendo expressa transitoriamente em células não neoplásicas, em condições de deficiência de Zn. Há quatro tipos de metalotioneínas em mamíferos, chamadas de isoformas 1, 2, 3 e 4. As posições das cisteínas são as mesmas nessas isoformas. As MT-1 e MT-2 são expressas em quase todos os órgãos do corpo e células em cultura, e são induzidas por uma grande variedade de agentes indutores de estresse, como metais pesados e agentes oxidativos. As MT-1 e MT-2 apresentam maior expressão no fígado, estando envolvidas na manutenção da homeostasia do Zn. MT-3 é expressa no cérebro e sua ação é de inibição da proliferação neuronal. A MT-4 é expressa especificamente em células epiteliais da língua e da pele e possui a função relacionada à diferenciação de células epiteliais escamosas de epitélios estratificados.

As MT-3 e MT-4 são constitutivamente expressas, já MT-1 e MT-2 tanto se apresentam constitutivamente expressas como podem ser induzidas por vários estímulos (BUTCHER et al., 2004). A maioria dos tecidos dos mamíferos contém níveis baixos de $\mathrm{MT}$, os quais podem variar com o tipo de tecido e com a idade. A MT hepática pode conter principalmente Zn e Cd, especialmente durante o período 
pré-natal e durante a gestação, enquanto a MT renal pode conter Cd, Cu e Zn (HAQ; MAHONEY; KOROPATNICK, 2003; SATO; KONDOH, 2002; THEOCHARIS et al., 2004; VASAK; HASLER, 2000).

Apesar de muitas décadas de intensas pesquisas, as precisas ações fisiológicas das MTs não têm sido totalmente identificadas. Levando em consideração suas ações de ligantes de metais, funções fisiológicas, tais como transporte e estocagem de íons essenciais (zinco, cobre) e detoxificação de outros íons não essenciais (cádmio, mercúrio), têm sido propostas. Outro modelo sugerido de função das metalotioneínas prega que essas proteínas serviriam de doadoras de Zn para proteínas, modulando a ligação do DNA a fatores de transcrição que apresentem estruturas ditas de dedos de zinco, como Sp1, TFIIA (CHERIAN; JAYASURYA; BAY, 2003; HAQ; MAHONEY; KOROPATNICK, 2003; THEOCHARIS et al., 2004; VASAK; HASLER, 2000). Às proteínas MT-1 e MT-2 têm sido sugerido um papel de chaperonas, fornecendo zinco e cobre, após injúria tecidual, a vários fatores de transcrição, metaloenzimas e fatores de crescimento requeridos para o reparo e rápido crescimento celular. Por outro lado, apo-MT é capaz de terminar, ao remover $\mathrm{Zn}$, a ligação de fatores de transcrição que apresentem dedos de $\mathrm{Zn}$ ao DNA (CHERIAN; JAYASURYA; BAY, 2003; CHERIAN; KANG, 2006; KIM et al., 2003; ROMERO-ISART; VASAK, 2002; SATO; KONDOH, 2002; VASAK; HASLER, 2000).

Outro interessante aspecto da reatividade da família das MTs é sua habilidade em reagir com alguns radicais livres. Nesse sentido, tem sido mostrado que MTs, em função de seu alto teor de cisteína, são eficientes captadoras de espécies reativas do oxigênio, como peróxido de oxigênio $\left(\mathrm{H}_{2} \mathrm{O}_{2}\right)$, hidroxilas $(\mathrm{OH})$, superóxido $\left(\mathrm{O}_{2}^{-}\right)$e óxido nítrico (NO), o que, dessa forma protege os tecidos contra 
injúrias oxidativas, entre as quais podem ser incluídos: a radiação, a peroxidação lipídica, o estresse oxidativo causado por drogas antineoplásicas e condições de hiperoxidação (CHERIAN; JAYASURYA; BAY, 2003; KIM et al., 2003; SATO; KONDOH, 2002; THEOCHARIS et al., 2004).

Outras adicionais funções sugeridas incluem adaptação de stress, regulação do crescimento neuronal e efeitos anti-apoptóticos (CHERIAN; JAYASURYA; BAY, 2003; ROMERO-ISART; VASAK, 2002; SATO; KONDOH, 2002). Os efeitos antiapoptóticos estão relacionados a uma interação específica com a subunidade p50 de NFKB, sendo que MT pode ser requerida para estabilizar a ligação de NFkB ao DNA, realizando, desse modo, seus efeitos anti-apoptóticos (VASAK; HASLER, 2000).

A abundância de ligantes tiolato cisteína, nas MTs, propicia à proteína uma afinidade para íons metálicos leves. Embora, naturalmente MTs, sejam geralmente isoladas com $\mathrm{Zn}(\mathrm{II}), \mathrm{Cd}(\mathrm{II})$ e $\mathrm{Cu}(\mathrm{I})$, um número grande de íons pode se ligar in vitro. Esses incluem $\mathrm{Ag}(\mathrm{I}), \mathrm{Au}(\mathrm{I}), \mathrm{Bi}(\mathrm{III}), \mathrm{Co}(\mathrm{II}), \mathrm{Fe}(\mathrm{II}), \mathrm{Hg}(\mathrm{II}), \mathrm{Ni}(\mathrm{II}), \mathrm{Pt}(\mathrm{II})$ e $\mathrm{Tc}(\mathrm{IV}) . \mathrm{A}$ ordem de afinidade de ligação dos íons metálicos aos locais com tiolatos inorgânicos é: $\mathrm{Hg}(\mathrm{II})>\mathrm{Ag}(\mathrm{I}) \sim \mathrm{Cu}(\mathrm{I})>\mathrm{Cd}(\mathrm{II})>\mathrm{Zn}(\mathrm{II}) \quad$ (CHERIAN; KANG, 2006; ROMERO-ISART; VASAK, 2002; SATO; KONDOH, 2002). Nessa linha de pensamento, à MT tem sido atribuído um papel na detoxificação de metais pesados, uma vez que MT possui afinidade menor com metais essenciais, como $\mathrm{Zn}$, e alta com metais pesados tóxicos, como Cd e Hg, como supramencionado (SATO; KONDOH, 2002). Convém mencionar, ainda, que a ligação de metais a MTs pode ser reversível sob condições de oxirredução e pela presença adequada de íons metálicos (ROMERO-ISART; VASAK, 2002). Assim, a liberação de Zn das metalotioneínas, dos grupos cisteínas sulfúricos, pode ocorrer sob condições de oxidação, já condições de redução 
conduziriam a ligação do Zn à MT (CHERAN; KANG, 2006; MARET, 2000). Dessa forma, MTs atuam também como um reservatório para aqueles metais, transferindo íons para macromoléculas celulares (THEOCHARIS et al., 2004).

Em humanos, os genes das MTs estão agrupados na região q13 do cromossomo 16 e incluem pelo menos 11 genes MT-1 (MT-1A, -B, -E, -F, -G, H, -I, J, $-K,-L$ e -X), alguns dos quais podem codificar RNAs não funcionais. Os genes MT-1 e MT-2 contêm regiões TATA boxes e iniciadora, necessárias para recrutar o fator de transcrição IID (TFIID), de uma região contendo uma série de elementos regulatórios de metal, chamada MREs (do inglês metal regulatory elements) que são requeridos para indução por metais, além de GRE (do inglês glucocorticoids regulatory elements), para indução de glicocorticosteróides e de uma região chamada ARE (do inglês oxidative agents regulatory elements). É importante salientar que MREs atuam em conjunção com fatores de transcrição dependentes de Zn, ditos MTF-1 (do inglês zinc-responsive transcription factor). Após estresse (hipóxia ou condições oxidativas) ou exposição a metais, MTF-1 transloca-se do citoplasma para o núcleo, onde se liga a MREs. As MT-3 e MT-4 são induzidas por mecanismos diferentes das MT-1 e MT-2, ainda não completamente elucidados. As expressões das MT-1 e MT-2 são induzidas por estresse químico promovido por

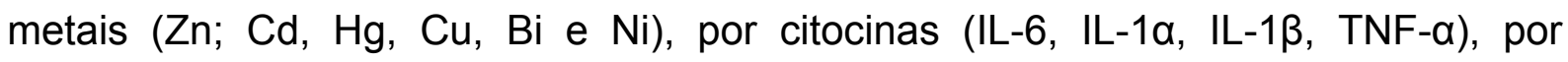
espécies reativas do oxigênio, glicocorticóides, por estresse físico via fatores de transcrição, assim como por alterações estruturais na cromatina (CHERIAN; JAYASURYA; BAY, 2003; HAQ; MAHONEY; KOROPATNICK, 2003; KIM et al., 2003; SATO; KONDOH, 2002; VASAK; HASLER, 2000).

Metilação do DNA pode reprimir a transcrição das MTs de alguns modos: inibindo a ligação de fatores de transcrição às regiões promotoras, recrutando co- 
repressores transcricionais e finalmente alterando a estrutura da cromatina (mediando acesso de ativadores ao DNA) (HAQ; MAHONEY; KOROPATNICK, 2003).

O aspecto característico de todas as metalotioneínas é a ocorrência da seqüência tripeptídica Cys-Xaa-Cys, onde Xaa representa um resíduo de aminoácido diferente de Cys (ROMERO-ISART; VASAK, 2002). Cada molécula de MT pode ligar-se a sete moléculas de $\mathrm{Zn}$ e $\mathrm{Cd}$ em dois domínios distintos, um domínio amino-terminal (grupo $\alpha$ ) e outro domínio carboxi-terminal (grupo $\beta$ ). Após quatro moléculas terem sido ligadas por 11 cisteínas no grupo $\alpha$, três moléculas de metal são capturadas por nove cisteínas no grupo $\beta$. Essas observações sugerem diferenças nas funções fisiológicas entre os dois grupos. Os estudos indicam que $\mathrm{Zn}$ no grupo $\beta$ está envolvido na regulação da respiração mitocondrial promovida pela MT (HAQ; MAHONEY; KOROPATNICK, 2003; MARET, 2000; SATO; KONDOH, 2002; VASAK; HASLER, 2000).

As MTs contêm de 60 a 68 aminoácidos, dos quais 20 são cisteínas altamente conservadas. A estrutura primária da MT-3 (68 aminoácidos) mostra um novo motif Cys(7)-Pro-Cys(8)-Pro e duas inserções: uma treonina na posição 5 e um ácido hexapeptídeo na posição 53, quando comparada com as clássicas seqüências das MT-1/MT-2 de 61 e 62 aminoácidos respectivamente. A presença dos dois novos e conservados resíduos Pro é importante para a atividade desta MT-3. Na estrutura primária da MT-4 epitelial, uma inserção Glu, também na posição 5 , foi encontrada. Já a MT-3 exibe $70 \%$ de identidade seqüencial com as isoformas MT1/MT-2 (ROMERO-ISART; VASAK, 2002). A estrutura tridimensional da $\mathrm{Cd}_{5}, \mathrm{Zn}_{2^{-}}$ MT-2 mostra uma proteína monomérica, em forma de halteres, com sete íons metálicos localizados em dois grupos distintos de metal-tiolato: uma distorcida 
cadeia com um grupo com três metais, $\mathrm{M}^{\mathrm{II}} \mathrm{Cy} \mathrm{S}_{9}$, localizado no domínio- $\beta$ N-terminal; um grupo com quatro metais, M4"Cys 11 no domínio- $\alpha$ C-terminal. Os íons metálicos encontrados são $\mathrm{Zn}(\mathrm{II})$ ou $\mathrm{Cd}(\mathrm{II})$. $\mathrm{Cd}_{7}-\mathrm{MT}-1$ mostra alta similaridade à $\mathrm{Cd}_{7}-\mathrm{MT}-2$.

A outra metalotioneína que possui a forma estrutural conhecida é a MT-3. Embora a localização dos grupos que contêm os íons metálicos seja desconhecida, sugere-se que o grupo $\mathrm{Cu}_{4}$ é mais provavelmente localizado no domínio- $\beta \mathrm{N}$-terminal da proteína, enquanto no domínio-a possua três íons zinco. Enfim, as propriedades estruturais gerais que caracterizam todas as metalotioneínas são a formação de grupos metal-tiolato, ligando os grupos cisteinil tiolato (HAQ; MAHONEY; KOROPATNICK, 2003; MARET, 2000; ROMERO-ISART; VASAK, 2002).

A composição de metal das proteínas nativas depende da origem natural e prévia exposição aos metais. As formas induzíveis MT-1 and MT-2 isoladas de um fígado de um adulto e de um feto humano contêm principalmente zinco, já aquelas isoladas de rins de adulto contêm principalmente cádmio, com algum cobre e zinco. No fígado e rins de mamíferos, as isoformas MT-3 e MT-4 contêm zinco e cobre. Enquanto nos mamíferos, as metalotioneínas ligam-se simultaneamente ao zinco, cádmio ou cobre, MTs de leveduras e fungos contêm exclusivamente cobre (ROMERO-ISART; VASAK, 2002).

2.4.1 Funções do $\mathrm{Zn}$ reguladas pela metalotioneína

O crescimento e a diferenciação das células eucarióticas são induzidos por hormônios e fatores de crescimento que disparam cascatas de sinalização 
intracelulares. Esses elementos incluem receptores de hormônios, segundo mensageiros intracelulares, proteínas quinases, proteínas fosfatases e fatores de transcrição. Em todos os níveis de transdução de sinais celulares, o Zn está envolvido ou como elemento estrutural (mais de mil fatores de transcrição que contêm domínios dedos de $\mathrm{Zn}$ ), ou como fator regulatório (conduzindo a proteína quinase C para a membrana plasmática). Zinco estimula a atividade do factor de transcrição MTF-1 (do inglês Metal response element-binding transcription factor-1), que controla a transcrição de genes da metalotioneína. Após ligar-se ao Zn, MTF-1 transloca-se do citoplasma para o núcleo, onde se liga à região MRE (do inglês metal response element), no gene promotor da MT, resultando em aumento da transcrição e síntese de tioneína, o qual se liga ao Zn disponível (BEYERSMANN; HAASE, 2001; HAQ; MAHONEY; KOROPATNICK, 2003; KIM et al., 2003; MARET, 2000).

A homeostasia do zinco é parcialmente controlada pela MT, a qual tem sido mostrada desempenhando um papel na regulação da proliferação celular. MT está expressa em tecidos que estão em proliferação, como em fígado de ratos, que estão regenerando-se, e em vários tumores. A maneira como o Zn é liberado de seus locais de ligação nas proteínas e é transferido para outro local permanece desconhecida (MARET, 2000; SATO; KONDOH, 2002; VASAK; HASLER, 2000).

Em últimas palavras, $\mathrm{Zn}$ serve como um fator sinalizador na regulagem da proliferação, diferenciação e morte celular (BEYERSMANN; HAASE, 2001). 


\subsubsection{Localização da metalotioneína na célula}

Precisar a localização da MT na célula é importante para o entendimento de suas funções fisiológicas. A MT é usualmente encontrada no citoplasma e transferida para o núcleo de hepatócitos, após hepatectomia parcial, sugerindo alterações na localização da MT celular dependentes do ciclo celular. A localização nuclear de MT em células, durante a proliferação (na transição da fase G1 para a fase S), durante o processo de diferenciação, ou, ainda, após injúria celular, indica que alta demanda de zinco é necessária para o reparo e síntese de DNA. Tais eventos coincidem com a indução da síntese de MT e seqüestro de Zn, e posterior transferência de Zn para as algumas enzimas (BEYERSMANN; HAASE, 2001; CHERIAN; JAYASURYA; BAY, 2003; CHERIAN; KANG, 2006; SATO; KONDOH, 2002).

Em pré-adipócitos e em miofibroblastos, a quantidade de MT no núcleo aumenta durante o processo de diferenciação celular. Três diferentes proteínas quinases possuem capacidade de translocar MT do citoplasma para o núcleo, durante a diferenciação celular: MAP quinase, PI3- quinase e P70S6-quinase. Como MT não é fosforilada por proteínas quinases, parece lícito afirmar que mediadores não conhecidos são necessários para translocação nuclear de MT. Altos níveis de Zn nuclear são necessários para as funções nucleares durante as etapas precoces e diferenciação celular (BEYERSMANN; HAASE, 2001).

MT localizada no citoplasma tem um efeito supressor dos danos oxidativos causados por ter-butilhidroperóxido e da citotoxicidade dos metais pesados, já MT localizada no núcleo não mostrou tais efeitos supressores de danos. MT nuclear 
também mostrou efeito protetor contra danos no DNA causado por radiação ultravioleta e peróxido de hidrogênio. Há uma correlação entre a malignidade da neoplasia e a quantidade de MT expressa em células neoplásicas, assim como a supressão da apoptose se relaciona com aumento da expressão da MT (BEYERSMANN; HAASE, 2001; SATO; KONDOH, 2002).

\section{PROPOSIÇÃO}

3.1 Correlacionar os aspectos clínicos com a imunoexpressão das proteínas pAKt, metalotioneína e NFKB em carcinomas epidermóides de boca.

3.2 Avaliar a utilização das proteínas pAKt, metalotioneína e NF-KB, como marcadores prognósticos de carcinomas epidermóides de boca.

3.3 Avaliar as imunoexpressões das proteínas pAkt, NF-kB e metalotioneína entre si. 


\section{MATERIAIS E MÉTODOS}

\subsection{Amostras dos tecidos}

Foi realizada uma análise retrospectiva dos prontuários de 51 pacientes, com carcinoma epidermóide de boca, através da consulta aos arquivos dos Hospitais Ofir Loyola - HOL, situado na região metropolitana de Belém no Estado do Pará e do Hospital Araújo Jorge, situado na região metropolitana de Goiânia. Ambos os hospitais são considerados como Centros de Alta Complexidade em Oncologia (CACON), pelo Instituto Nacional do Câncer - INCA. Esta pesquisa foi aprovada pelo Comitê de Ética em Pesquisa da USP, protocolo $n^{\circ}$ 45/06 de 04 de abril de 2006 (Anexo A).

As variáveis estudadas foram retiradas dos prontuários dos pacientes, os quais foram resumidos em formulários padronizados e arquivados em um banco de dados informatizado no Registro Hospitalar do Câncer - RHC. Foram incluídos no estudo todos os pacientes com diagnóstico de carcinoma epidermóide de boca, confirmados através de laudo histopatológico, no período compreendido entre 01 de janeiro de 1997 a 31 de dezembro de 2003. Os pacientes foram acompanhados por período máximo de 60 meses após o diagnóstico inicial.

Os dados clínicos coletados foram: sexo, idade, consumo de tabaco e de bebidas alcoólicas, localização anatômica da lesão, estadiamento (TNM), tratamento cirúrgico e presença de recidiva (Quadros 4.1 e 4.2). A classificação clínica TNM considera as lesões de acordo com as dimensões do tumor primário $(\mathrm{T})$, $\mathrm{o}$ comprometimento de linfonodos regionais $(\mathrm{N})$ e metástase à distância $(\mathrm{M})$, que foi 
preconizada pela União UICC (Internacional Contra o Câncer) e pela AJCC

(American Joint Committee on Cancer), em 1982 (Quadros 4.3 e 4.4).

\begin{tabular}{|c|c|c|c|c|c|c|c|c|c|c|}
\hline PAC & IDADE & SEXO & FUMANTE & ETILISMO & LOCAL & $T$ & $\mathbf{N}$ & $\mathbf{M}$ & EST & TRAT. CIR. \\
\hline 01 & 53 & MASC & VERDADEIRO & VERDADEIRO & M. JUGAL & 4 & 0 & 0 & IV & FALSO \\
\hline 02 & 64 & MASC & VERDADEIRO & VERDADEIRO & LINGUA & 3 & 0 & 0 & III & VERDADEIRO \\
\hline 03 & 75 & FEM & VERDADEIRO & VERDADEIRO & ASSOALHO & 4 & 1 & 0 & IV & FALSO \\
\hline 04 & 33 & MASC & FALSO & FALSO & LÍNGUA & 3 & 0 & 0 & III & VERDADEIRO \\
\hline 05 & 54 & MASC & VERDADEIRO & VERDADEIRO & LINGUA & 1 & 0 & 0 & I & VERDADEIRO \\
\hline 06 & 66 & FEM & FALSO & FALSO & PALATO & 4 & 1 & 0 & IV & VERDADEIRO \\
\hline 07 & 56 & MASC & FUMANTE & FALSO & LÍNGUA & 2 & 0 & 0 & II & VERDADEIRO \\
\hline 08 & 52 & MASC & VERDADEIRO & VERDADEIRO & REBORDO & 4 & 0 & 0 & IV & VERDADEIRO \\
\hline 09 & 74 & FEM & VERDADEIRO & VERDADEIRO & REBORDO & 4 & 0 & 0 & IV & VERDADEIRO \\
\hline 10 & 64 & MASC & VERDADEIRO & VERDADEIRO & ASSOALHO & 1 & 3 & 0 & IV & VERDADEIRO \\
\hline 11 & 53 & MASC & VERDADEIRO & VERDADEIRO & REBORDO & 4 & 1 & 0 & IV & VERDADEIRO \\
\hline 12 & 66 & MASC & VERDADEIRO & VERDADEIRO & PALATO & 4 & 0 & 0 & IV & FALSO \\
\hline 13 & 63 & FEM & VERDADEIRO & FALSO & LINGUA & 4 & 1 & 0 & IV & FALSO \\
\hline 14 & 62 & MASC & VERDADEIRO & VERDADEIRO & REBORDO & 4 & 0 & 0 & IV & VERDADEIRO \\
\hline 15 & 66 & MASC & FALSO & FALSO & LINGUA & 3 & 0 & 0 & III & VERDADEIRO \\
\hline 16 & 64 & FEM & VERDADEIRO & VERDADEIRO & TRIGONO & 4 & 0 & 0 & IV & FALSO \\
\hline 17 & 60 & MASC & VERDADEIRO & VERDADEIRO & TRIGONO & 4 & 1 & 0 & IV & FALSO \\
\hline 18 & 69 & FEM & FALSO & FALSO & M. JUGAL & 3 & 0 & 0 & III & VERDADEIRO \\
\hline 19 & 79 & FEM & VERDADEIRO & FALSO & REBORDO & 4 & 0 & 0 & IV & FALSO \\
\hline 20 & 68 & MASC & VERDADEIRO & VERDADEIRO & ASSOALHO & 2 & 0 & 0 & II & VERDADEIRO \\
\hline 21 & 56 & MASC & VERDADEIRO & VERDADEIRO & ASSOALHO & 4 & 1 & 0 & IV & VERDADEIRO \\
\hline 22 & 79 & MASC & VERDADEIRO & VERDADEIRO & TRIGONO & 2 & 0 & 0 & II & VERDADEIRO \\
\hline 23 & 41 & MASC & FALSO & FALSO & PALATO & 2 & 2 & 0 & IV & VERDADEIRO \\
\hline 24 & 75 & MASC & VERDADEIRO & VERDADEIRO & ASSOALHO & 3 & 2 & 0 & IV & FALSO \\
\hline 25 & 65 & MASC & VERDADEIRO & VERDADEIRO & LINGUA & 4 & 2 & 0 & IV & FALSO \\
\hline 26 & 43 & MASC & FALSO & FALSO & ASSOALHO & 4 & 3 & 0 & IV & VERDAEIRO \\
\hline 27 & 53 & MASC & VERDADEIRO & VERDADEIRO & LIINGUA & 3 & 2 & 0 & IV & VERDADEIRO \\
\hline 28 & 85 & FEM & VERDADEIRO & FALSO & LINGUA & 3 & 0 & 0 & III & VERDADEIRO \\
\hline 29 & 70 & FEM & VERDADEIRO & FALSO & LÍNGUA & 4 & 2 & 0 & IV & FALSO \\
\hline 30 & 45 & MASC & VERDADEIRO & VERDADEIRO & ASSOALHO & 2 & 2 & 0 & IV & VERDADEIRO \\
\hline 31 & 69 & MASC & VERDADEIRO & VERDADEIRO & LINGUA & 3 & 0 & 0 & III & VERDADEIRO \\
\hline 32 & 68 & MASC & VERDADEIRO & VERDADEIRO & ASSOALHO & 3 & 0 & $\mathrm{x}$ & III & FALSO \\
\hline 33 & 73 & MASC & VERDADEIRO & VERDADEIRO & LÍNGUA & 4 & 2 & $\mathrm{x}$ & IV & FALSO \\
\hline 34 & 73 & MASC & VERDADEIRO & VERDADEIRO & LINGUA & 2 & 2 & $\mathrm{x}$ & IV & FALSO \\
\hline 35 & 63 & FEM & VERDADEIRO & FAl & LÍNGUA & 4 & 3 & 0 & IV & FALSO \\
\hline 36 & 60 & MASC & VERDADEIRO & VERDADEIRO & ASSOALHO & 2 & 1 & 0 & III & VERDADEIRO \\
\hline 37 & 74 & MASC & VERDADEIRO & VERDADEIRO & LINGUA & 4 & 2 & 0 & IV & FALSO \\
\hline 38 & 84 & FEM & VERDADEIRO & & LINGUA & 3 & 1 & 0 & III & VERDADEIRO \\
\hline 39 & 27 & FEM & FALSO & FA & LÍNGUA & 2 & 0 & 0 & II & VERDADEIRO \\
\hline 40 & 74 & FEM & VERDADEIRO & VERDADEIRO & LÍNGUA & 3 & 2 & $\mathrm{x}$ & IV & VERDADEIRO \\
\hline 41 & 71 & MASC & VERDADEIRO & FALSO & LÍNGUA & 3 & 3 & 0 & IV & FALSO \\
\hline 42 & 65 & MASC & VERDADEIRO & VERDADEIRO & LÍNGUA & 3 & 0 & 0 & III & VERDADEIRO \\
\hline 43 & 59 & MASC & FALSO & FALSO & LINGUA & 3 & 2 & 0 & IV & VERDADEIRO \\
\hline 44 & 67 & MASC & VERDADEIRO & VERDADEIRO & ASSOALHO & 3 & 2 & 1 & IV & FALSO \\
\hline 45 & 71 & MASC & VERDADEIRO & VERDADEIRO & LINGUA & 2 & 0 & 0 & II & VERDADEIRO \\
\hline 46 & 60 & MASC & VERDADEIRO & VERDADEIRO & ASSOALHO & 4 & 2 & 0 & IV & FALSO \\
\hline 47 & 25 & MASC & FALSO & FALSO & LINGUA & 4 & 1 & 0 & IV & FALSO \\
\hline 48 & 93 & FEM & VERDADEIRO & FALSO & LINGUA & 3 & 1 & 0 & III & FALSO \\
\hline 49 & 43 & FEM & VERDADEIRO & VERDADEIRO & ASSOALHO & 4 & 2 & 0 & IV & VERDADEIRO \\
\hline 50 & 72 & MASC & VERDADEIRO & FALSO & LINGUA & 4 & 1 & 0 & IV & FALSO \\
\hline 51 & 39 & MASC & VERDADEIRO & FALSO & LINGUA & 4 & 3 & 0 & IV & FALSO \\
\hline
\end{tabular}

Quadro 4.1 - Dados clínicos coletados 


\begin{tabular}{|c|c|c|c|c|}
\hline PACIENTE & HOUVE RECIDIVA & APÓS O TRAT. & DATA TRAT. & ÓBITO/ ÚLT.CONS. \\
\hline 01 & FALSO & OBITO & $2 / 11 / 1999$ & $02 / 08 / 2000$ \\
\hline 02 & FALSO & OBITO & 2/07/1999 & 18/11/1999 \\
\hline 03 & FALSO & ACOMPANHAMENTO & $21 / 06 / 2001$ & $31 / 08 / 2006$ \\
\hline 04 & VERDADEIRO & ACOMPANHAMENTO & $3 / 01 / 2002$ & $13 / 02 / 2007$ \\
\hline 05 & FALSO & OBITO & $3 / 10 / 2002$ & $24 / 06 / 2005$ \\
\hline 06 & FALSO & ACOMPANHAMENTO & $19 / 03 / 2002$ & $11 / 06 / 2007$ \\
\hline 07 & VERDADEIRO & ACOMPANHAMENTO & $10 / 06 / 1997$ & $12 / 07 / 2001$ \\
\hline 08 & FALSO & OBITO & $19 / 03 / 2004$ & $30 / 06 / 2007$ \\
\hline 09 & FALSO & ACOMPANHAMENTO & $6 / 11 / 2003$ & $22 / 08 / 2007$ \\
\hline 10 & FALSO & ACOMPANHAMENTO & $8 / 04 / 2003$ & $22 / 08 / 2007$ \\
\hline 11 & FALSO & OBITO & $18 / 11 / 2003$ & $23 / 01 / 2003$ \\
\hline 12 & FALSO & OBITO & $5 / 03 / 2004$ & 09/03/2004 \\
\hline 13 & FALSO & OBITO & $21 / 01 / 2004$ & $28 / 02 / 2004$ \\
\hline 14 & FALSO & OBITO & $6 / 06 / 2003$ & $10 / 09 / 2003$ \\
\hline 15 & VERDADEIRO & OBITO & $10 / 03 / 2003$ & $24 / 01 / 2004$ \\
\hline 16 & FALSO & OBITO & $15 / 05 / 2000$ & $17 / 07 / 2001$ \\
\hline 17 & VERDADEIRO & OBITO & $31 / 01 / 2001$ & $01 / 06 / 2002$ \\
\hline 18 & FALSO & OBITO & 28/07/1998 & $04 / 05 / 2004$ \\
\hline 19 & FALSO & OBITO & $14 / 03 / 2002$ & $29 / 11 / 2002$ \\
\hline 20 & VERDADEIRO & OBITO & 20/05/1999 & $20 / 04 / 2003$ \\
\hline 21 & FALSO & OBITO & $09 / 03 / 2000$ & $19 / 06 / 2000$ \\
\hline 22 & FALSO & OBITO & $18 / 09 / 2001$ & $10 / 01 / 2002$ \\
\hline 23 & VERDADEIRO & OBITO & $14 / 07 / 2004$ & $15 / 05 / 2006$ \\
\hline 24 & FALSO & ÓBITO & $9 / 04 / 2002$ & $30 / 09 / 2002$ \\
\hline 25 & VERDADEIRO & ACOMPANHAMENTO & $14 / 11 / 2002$ & $30 / 06 / 2004$ \\
\hline 26 & FALSO & ÓBITO & $28 / 05 / 2002$ & $12 / 07 / 2002$ \\
\hline 27 & FALSO & ÓBITO & $8 / 10 / 2002$ & $29 / 04 / 2003$ \\
\hline 28 & FALSO & ACOMPANHAMENTO & $4 / 11 / 2002$ & $11 / 04 / 006$ \\
\hline 29 & FALSO & ÓBITO & $5 / 07 / 2002$ & $05 / 12 / 2002$ \\
\hline 30 & FALSO & ÓBITO & $2 / 03 / 2002$ & 03/12/2005 \\
\hline 31 & FALSO & ÓBITO & $31 / 10 / 2002$ & $12 / 09 / 2004$ \\
\hline 32 & FALSO & ÓBITO & $4 / 11 / 1998$ & $24 / 11 / 1998$ \\
\hline 33 & FALSO & ÓBITO & $16 / 06 / 2002$ & $13 / 08 / 2003$ \\
\hline 34 & FALSO & ÓBITO & $19 / 11 / 1999$ & $08 / 09 / 2000$ \\
\hline 35 & FALSO & ACOMPANHAMENTO & $17 / 12 / 2001$ & $10 / 11 / 2006$ \\
\hline 36 & FALSO & ÓBITO & $29 / 07 / 2002$ & $02 / 09 / 2002$ \\
\hline 37 & VERDADEIRO & ÓBITO & $20 / 08 / 2002$ & $22 / 07 / 2003$ \\
\hline 38 & FALSO & ÓBITO & $26 / 09 / 2001$ & $15 / 02 / 2002$ \\
\hline 39 & FALSO & ACOMPANHAMENTO & $7 / 02 / 2002$ & $31 / 01 / 2007$ \\
\hline 40 & FALSO & OBITO & $9 / 11 / 1998$ & $11 / 12 / 1998$ \\
\hline 41 & FALSO & OBITO & $18 / 06 / 1998$ & 17/08/1998 \\
\hline 42 & FALSO & ACOMPANHAMENTO & $25 / 06 / 2002$ & $23 / 12 / 2005$ \\
\hline 43 & FALSO & ÓBITO & $30 / 11 / 1998$ & 05/03/1999 \\
\hline 44 & FALSO & ÓBITO & $25 / 03 / 2002$ & $17 / 06 / 2002$ \\
\hline 45 & FALSO & ACOMPANHAMENTO & $2 / 09 / 2002$ & $21 / 02 / 2007$ \\
\hline 46 & FALSO & ÓBITO & $30 / 07 / 2001$ & 02/10/2001 \\
\hline 47 & FALSO & OBITO & $16 / 11 / 2000$ & 09/11/2001 \\
\hline 48 & FALSO & OBITO & $16 / 03 / 2000$ & $19 / 08 / 2000$ \\
\hline 49 & FALSO & ACOMPANHAMENTO & $18 / 02 / 2002$ & $26 / 11 / 2006$ \\
\hline 50 & FALSO & OBITO & $12 / 06 / 1999$ & $10 / 02 / 2000$ \\
\hline 51 & FALSO & OBITO & $13 / 11 / 2003$ & $18 / 12 / 2003$ \\
\hline
\end{tabular}




\begin{tabular}{|c|c|c|}
\hline Tumor Primário $(\mathrm{T})$ & Envolvimento nodal (N) & Metástase a distância (M) \\
\hline $\begin{array}{l}\text { Tx Tumor primário não pode } \\
\text { ser avaliado. }\end{array}$ & $\begin{array}{l}\text { Nx Linfonodos regionais não } \\
\text { podem ser avaliados. }\end{array}$ & $\begin{array}{l}\text { Mx Metástase a distância não } \\
\text { pode ser avaliada }\end{array}$ \\
\hline $\begin{array}{l}\text { T0 Não há evidência de } \\
\text { tumor primário }\end{array}$ & $\begin{array}{l}\text { N0 Ausência de metástases } \\
\text { regionais. }\end{array}$ & $\begin{array}{l}\text { Mo Ausência de metástase a } \\
\text { distância. }\end{array}$ \\
\hline Carcinoma in situ & $\begin{array}{l}\text { N1 Metástase em linfonodo } \\
\text { ipsilateral único, menor ou } \\
\text { igual a } 3 \mathrm{~cm} \text {, em seu maior } \\
\text { diâmetro }\end{array}$ & $\begin{array}{l}\text { M1 Presença de metástase a } \\
\text { distância. }\end{array}$ \\
\hline $\begin{array}{l}\text { T1 Tumor de até } 2 \mathrm{~cm} \text {, em } \\
\text { seu maior diâmetro }\end{array}$ & $\begin{array}{l}\text { N2a Metástase em linfonodo } \\
\text { ipsilateral único, maior que } 3 \\
\mathrm{~cm} \text {, mas menor que } 6 \mathrm{~cm} \text {, em } \\
\text { seu maior diâmetro. }\end{array}$ & \\
\hline $\begin{array}{l}\text { T2 Tumor maior que } 2 \mathrm{~cm} \text {, } \\
\text { mas menor que } 4 \mathrm{~cm} \text {, em } \\
\text { seu maior diâmetro }\end{array}$ & $\begin{array}{l}\text { N2b Metástase em linfonodos } \\
\text { ipsilaterais múltiplos, nenhum } \\
\text { maior que } 6 \text {, em seu maior } \\
\text { diâmetro. }\end{array}$ & \\
\hline $\begin{array}{l}\text { T3 Tumor maior que } 4 \mathrm{~cm} \text {, } \\
\text { em seu maior diâmetro }\end{array}$ & $\begin{array}{l}\text { N2c Metástase em linfonodos } \\
\text { bilaterais ou contralaterais, } \\
\text { nenhum maior que } 6 \mathrm{~cm} \text {, em } \\
\text { seu maior diâmetro. }\end{array}$ & \\
\hline $\begin{array}{l}\text { T4 Tumor maior que } 4 \mathrm{~cm} \text {, } \\
\text { com invasão de estruturas } \\
\text { adjacentes }\end{array}$ & $\begin{array}{l}\text { N3 Metástase em linfonodos } \\
\text { maior que } 6 \mathrm{~cm} \text {, em seu } \\
\text { maior diâmetro. }\end{array}$ & \\
\hline
\end{tabular}

Quadro 4.3 - Classificação clínica TNM

\begin{tabular}{|c|c|c|c|}
\hline \multicolumn{4}{|c|}{ ESTADIAMENTO } \\
TNM \\
\hline 0 & Tis & N0 & M0 \\
\hline I & T1 & N0 & M0 \\
\hline II & T2 & N0 & M0 \\
\hline III & T3 & N0 & M0 \\
& T1 & N1 & M0 \\
& T2 & N1 & M0 \\
& T3 & N1 & M0 \\
\hline IV A & T4 & N0 & M0 \\
& qualquer T & N2 & M0 \\
\hline IV B & qualquer T & N3 & M0 \\
\hline IV C & qualquer T & qualquer N & M1 \\
\hline
\end{tabular}

Quadro 4.4 - Estadiamento TNM 


\subsection{Técnica de imunoistoquímica}

Foram selecionadas 51 amostras emblocadas em parafina provenientes do arquivo do Serviço de Patologia Cirúrgica do Hospital Ofir Loyola e do Hospital Antônio Jorge. As reações foram realizadas no laboratório de imunoistoquímica da Disciplina de Patologia Bucal da FOUSP, e a padronização para utilização de cada um dos anticorpos utilizados foi determinada no próprio laboratório da disciplina.

As reações foram desenvolvidas em cortes histológicos de $3 \mu \mathrm{m}$ de espessura, estendidos em lâminas de vidro, previamente lavadas em etanol absoluto, secas e mergulhadas por cinco minutos em solução de 3aminopropyltriethoxy-silano a 10\% (Sigma Chemical, St. Louis, USA) diluída em etanol absoluto.

Os cortes foram desparafinizados em dois banhos de xilol, o primeiro por 30 minutos, em estufa a $60^{\circ} \mathrm{C}$ e o segundo por 20 minutos, em temperatura ambiente. Em seguida os cortes foram reidratados em banhos descendentes, com passagem em etanol absoluto por três vezes, etanol $95 \%$ e etanol $85 \%$, por cinco minutos cada. Posteriormente, para remoção do pigmento formólico, os cortes foram imersos por dez minutos, em solução de hidróxido de amônio a 10\%, em etanol a $95 \%$.

Após lavagem em água corrente por 10 minutos, seguida por banhos em água destilada, as lâminas receberam tratamento para recuperação antigênica. Para a recuperação antigênica, as lâminas, que receberam os anticorpos antimetalotioneína e antiNF-kB foram mergulhadas em solução contendo 1,21 g de Tris, 0,3722 de EDTA e 500 microlitros de Tween, com ph 9,0, e levadas por 15 minutos em microondas potência máxima. As lâminas que receberam o anticorpo antipAkt 12-3 foram mergulhadas em solução de ácido cítrico monoidratado $10 \mathrm{mM}, \mathrm{pH} 6 \mathrm{e}$ 
colocadas em banho maria por 30 minutos a $95^{\circ} \mathrm{C}$. Posteriormente, os cortes foram lavados em água corrente por 10 minutos, com duas passagens subseqüentes em água destilada.

Posteriormente, para a inibição da peroxidase endógena, os cortes passaram por dois banhos de 15 minutos em peróxido de hidrogênio $6 \%$ em metanol $(1: 1, \mathrm{v} / \mathrm{v})$. Novamente, os cortes foram lavados em água corrente por 10 minutos e, posteriormente, imersos em três banhos de solução de Tris ph 7,4, por cinco minutos cada.

As lâminas, contendo os cortes, foram submetidas à incubação, com o anticorpo primário diluído em solução de BSA (mistura da solução A contendo água destilada e albumina, com a solução B contendo água destilada e azida sódica). Para a identificação da proteína pAKt, foi utilizado o anticorpo monoclonal obtido de coelho antipAkt 1/2/3 (Thr 308)-R: sc-16646-R (Santa Cruz Biotechnololy), sob diluição $1 / 50$ por 60 minutos de incubação. Para identificação da proteína metalotioneína foi utilizado o anticorpo monoclonal antimetalotioneína obtido de camundongo (DAKO- Corporation, Glostrup, Denmark) clone E9, subtipos MT1 e MT2, sob diluição $1 / 800$, por 60 minutos de incubação. Para a identificação da proteína NF-kB, foi utilizado o anticorpo obtido em coelho antiNF-kB (p65) (Zymed Laboratories), sob diluição $1 / 600$ por 30 minutos. Em seguida, as lâminas foram lavadas em água destilada e em solução tampão de TRIS pH 7,4. O kit LSAB peroxidase K0690 (DAKO Corporation) foi utilizado como soro secundário e complexo terciário por 30 minutos cada. Posteriormente as lâminas foram lavadas em TRIS ph 7,4 dois banhos de cinco minutos.

A revelação da reação foi feita através da imersão das lâminas em solução do cromógeno diaminobenzidina (DAB, 3,3 - diaminobenizidina, Sigma Chemical CO., 
St Louis, MO/USA) por dez minutos. Os cortes foram, então, lavados em água corrente e contracorados com hematoxilina de Mayer por dez minutos. Em seguida, os cortes foram lavados em água corrente por 10 minutos.

As lâminas sofreram, finalmente, as etapas de desidratação em cadeia ascendente de etanóis e diafanização em dois banhos de xylol. As lâminas foram montadas em Permount (Fisher Scientific, Fair Law, NJ/USA) para exame ao microscópio de luz.

Como controle positivo para a proteína metalotioneína, foi utilizado carcinoma de mama, e para pAkt 1/2/3 e NF-kB foram utilizados cortes de adenocarcinoma de próstata. O controle negativo foi obtido com a supressão do anticorpo primário durante a realização da reação.

\subsection{Análise da imunomarcação}

A reação foi considerada positiva quando houve a presença da coloração castanha, condição caracterizadora da presença do cromógeno DAB, na reação imunoistoquímica, e negativa para as células que não apresentaram marcação castanha. As lâminas foram observadas em microscópio de luz, modelo Olympus CX40, sob um foco fixo e com clareza de campo.

O sistema de contagem usado, nesse estudo, foi empregado anteriormente na literatura (TSURUTANI et al., 2006). A análise da marcação foi baseada na intensidade e na distribuição da marcação. A distribuição de células marcadas foi analisada da seguinte forma: $0(0 \%), 1(1 \%$ a $50 \%), 2$ (51\% a $100 \%)$, A intensidade 
da marcação foi avaliada da seguinte maneira: 0 (sem marcação), 1 (leve marcação), 2 (moderada marcação) e 3 (forte marcação). As lâminas foram analisadas por dois observadores independentes e que não conheciam os dados clínicos dos pacientes. Um consenso foi obtido para cada lâmina investigada. $\mathrm{O}$ padrão de marcação das biópsias foi definido com a somatória dos valores encontrados na distribuição da imunomarcação com os índices encontrados na intensidade, ficando o registro final (RF) da seguinte forma: RF0, RF2, RF3, RF4 e RF5. Nesse método, os RF0 e RF2 foram considerados como marcação negativa, enquanto os RF3, RF4 e RF5 foram considerados como marcação positiva.

\subsection{Análise estatística}

A análise estatística teve o objetivo de avaliar os efeitos da presença das proteínas pAKt, Metalotioneina e NF-KB sobre as caracteríscas clinicas e histológicas de 51 pacientes portadores de carcinomas epidermóides de boca. Foram aplicados métodos estatísticos descritivos e inferenciais. Para os testes de hipóteses foi prefixado o nível de significância $\alpha=0.05$ para rejeição da hipótese de nulidade.

A análise univariada da distribuição do tempo de sobrevida foi realizada pelo Logrank test. As curvas de distribuição da sobrevida foram estimadas pelo diagrama de Kaplan-Meier. As variáveis consideradas significantes na análise univariada ( $p$ valor $<0.05)$ foram selecionadas para o modelo de análise multivariada, o método 
Cox de risco proporcional testou a influência das covariáveis sobre o tempo de sobrevivência dos pacientes.

Para avaliar a associação entre a ocorrências das proteínas pAKt, metalotioneina e NF-KB e o estadiamento e a recidiva foi aplicado um método nãoparamétrico, o teste do Qui-Quadrado. A distribuição das proporções de ocorrência da presença das proteínas, ilustrada pelo diagrama Venn, foi testada pelo método do Qui-Quadrado.

A concordância e discordância entre a presença das proteínas no mesmo paciente, portando uma análise de amostras pareadas foi realizada através do método de McNemar.

Todo o processamento estatístico foi realizado sob o suporte computacional do pacote bioestatístico BioEstat versão 4 (AYRES et al., 2008). 
5 RESULTADOS

\subsection{Imunomarcações das proteínas pAkt, NF-kB e metalotioneína}

Concluídas as reações de imunoistoquímica os resultados indicaram imunomarcação positiva para pAkt em 36 amostras (70,58\%), para MT em 34 amostras (66,67\%) e para NF-kB em 33 amostras (64,70\%)(Quadro 5.1).

\begin{tabular}{|c|c|c|c|}
\hline PACIENTE & pAkt & Metalotioneína & NF-kB \\
\hline 01 & POSITIVO & POSITIVO & POSITIVO \\
\hline 02 & POSITIVO & POSITIVO & POSITIVO \\
\hline 03 & POSITIVO & POSITIVO & POSITIVO \\
\hline 04 & POSITIVO & POSITIVO & POSITIVO \\
\hline 05 & POSITIVO & POSITIVO & POSITIVO \\
\hline 06 & POSITIVO & NEGATIVO & POSITIVO \\
\hline 07 & POSITIVO & POSITIVO & POSITIVO \\
\hline 08 & POSITIVO & NEGATIVO & POSITIVO \\
\hline 09 & NEGATIVO & POSITIVO & NEGATIVO \\
\hline 10 & POSITIVO & NEGATIVO & POSITIVO \\
\hline 11 & NEGATIVO & NEGATIVO & NEGATIVO \\
\hline 12 & POSITIVO & POSITIVO & POSITIVO \\
\hline 13 & NEGATIVO & POSITIVO & POSITIVO \\
\hline 14 & NEGATIVO & NEGATIVO & POSITIVO \\
\hline 15 & POSITIVO & NEGATIVO & POSITIVO \\
\hline 16 & POSITIVO & NEGATIVO & POSITIVO \\
\hline 17 & POSITIVO & POSITIVO & POSITIVO \\
\hline 18 & POSITIVO & POSITIVO & POSITIVO \\
\hline 19 & POSITIVO & POSITIVO & POSITIVO \\
\hline 20 & POSITIVO & NEGATIVO & POSITIVO \\
\hline 21 & NEGATIVO & POSITIVO & POSITIVO \\
\hline 22 & POSITIVO & POSITIVO & NEGATIVO \\
\hline 23 & NEGATIVO & POSITIVO & POSITIVO \\
\hline 24 & NEGATIVO & POSITIVO & NEGATIVO \\
\hline 25 & POSITIVO & NEGATIVO & POSITIVO \\
\hline 26 & POSITIVO & POSITIVO & NEGATIVO \\
\hline 27 & NEGATIVO & POSITIVO & POSITIVO \\
\hline 28 & POSITIVO & POSITIVO & POSITIVO \\
\hline 29 & POSITIVO & POSITIVO & POSITIVO \\
\hline 30 & POSITIVO & NEGATIVO & POSITIVO \\
\hline 31 & POSITIVO & NEGATIVO & NEGATIVO \\
\hline 32 & POSITIVO & NEGATIVO & NEGATIVO \\
\hline 33 & POSITIVO & POSITIVO & POSITIVO \\
\hline 34 & POSITIVO & POSITIVO & POSITIVO \\
\hline 35 & POSITIVO & POSITIVO & NEGATIVO \\
\hline 36 & POSITIVO & NEGATIVO & POSITIVO \\
\hline 37 & NEGATIVO & POSITIVO & NEGATIVO \\
\hline 38 & POSITIVO & NEGATIVO & NEGATIVO \\
\hline 39 & POSITIVO & POSITIVO & POSITIVO \\
\hline 40 & NEGATIVO & POSITIVO & NEGATIVO \\
\hline 41 & NEGATIVO & NEGATIVO & POSITIVO \\
\hline 42 & POSITIVO & POSITIVO & NEGATIVO \\
\hline 43 & NEGATIVO & POSITIVO & POSITIVO \\
\hline 44 & POSITIVO & POSITIVO & NEGATIVO \\
\hline 45 & POSITIVO & POSITIVO & NEGATIVO \\
\hline 46 & POSITIVO & NEGATIVO & POSITIVO \\
\hline 47 & NEGATIVO & POSITIVO & NEGATIVO \\
\hline 48 & POSITIVO & POSITIVO & NEGATIVO \\
\hline 49 & NEGATIVO & POSITIVO & NEGATIVO \\
\hline 50 & NEGATIVO & POSITIVO & NEGATIVO \\
\hline 51 & POSITIVO & NEGATIVO & POSITIVO \\
\hline
\end{tabular}

Quadro 5.1 - Imunomarcações das proteínas pAkt, metalotioneína e NF-kB 


\subsection{Distribuição da imunoexpressão das proteínas pAkt, NF-kB e} metalotioneína

Somente $2 \%$ dos casos estudados apresentaram total ausência de marcação para as proteínas avaliadas e $43,1 \%$ das amostras demonstraram imunomarcação positiva para as três proteínas simultâneamente, o restante apontou imunomarcação variada (Tabela 5.1 e Gráfico 5.1).

Tabela 5.1 - Distribuição da presença das proteínas

\begin{tabular}{l|c|c}
\hline & $\mathbf{n}$ & $\begin{array}{c}\text { Resultados Positivos } \\
\%\end{array}$ \\
\hline Nenhuma proteína & 1 & 2.0 \\
Só NF-kB & 2 & 3.9 \\
Só pAkt & 3 & 5.9 \\
Só Metalotioneína & 3 & 5.9 \\
pAkt e NF-kB & 7 & 13.7 \\
pAkt e Metalotioneína & 4 & 7.8 \\
NF-kB e Metalotioneína & 9 & 17.6 \\
Três Proteínas & 22 & 43.1 \\
\hline Total & 51 & 100.0 \\
\hline
\end{tabular}

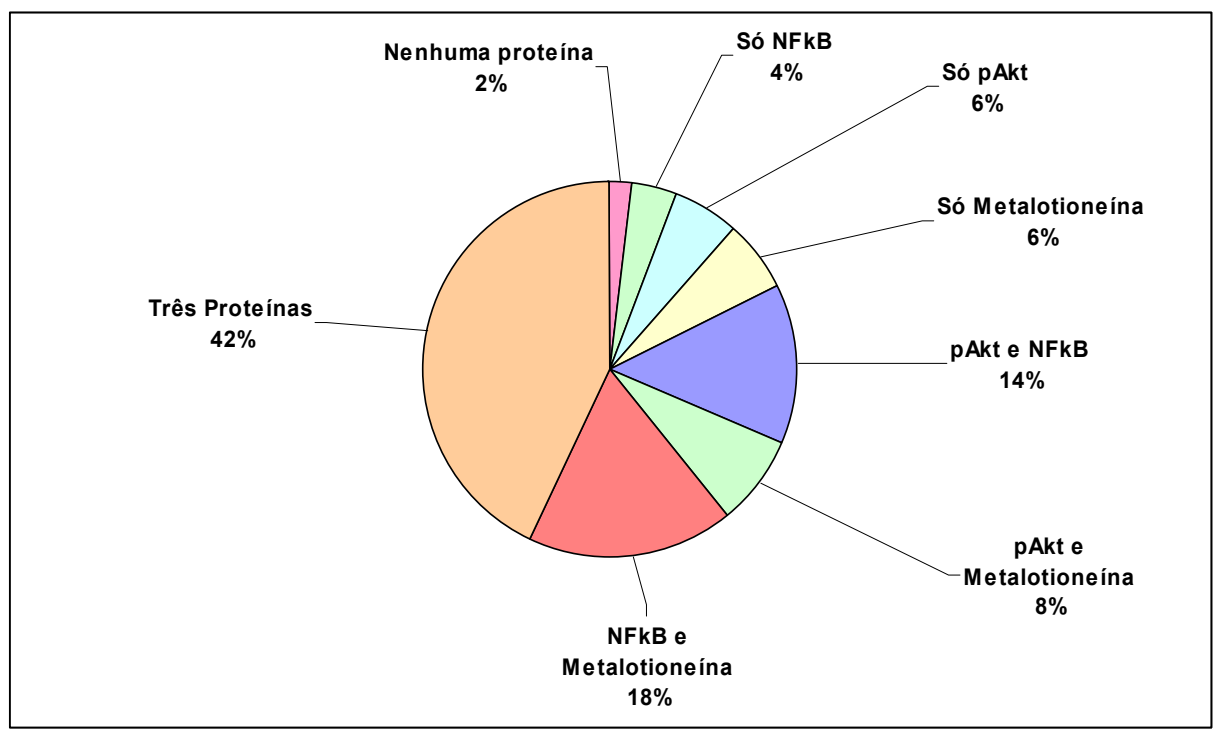

Gráfico 5.1 - Distribuição da presença das proteínas 
Como representado no gráfico 5.1 é mais significativa a confluência das proteínas pAkt, NF-kB e MT nos casos de carcinoma epidermóide aqui avaliados.

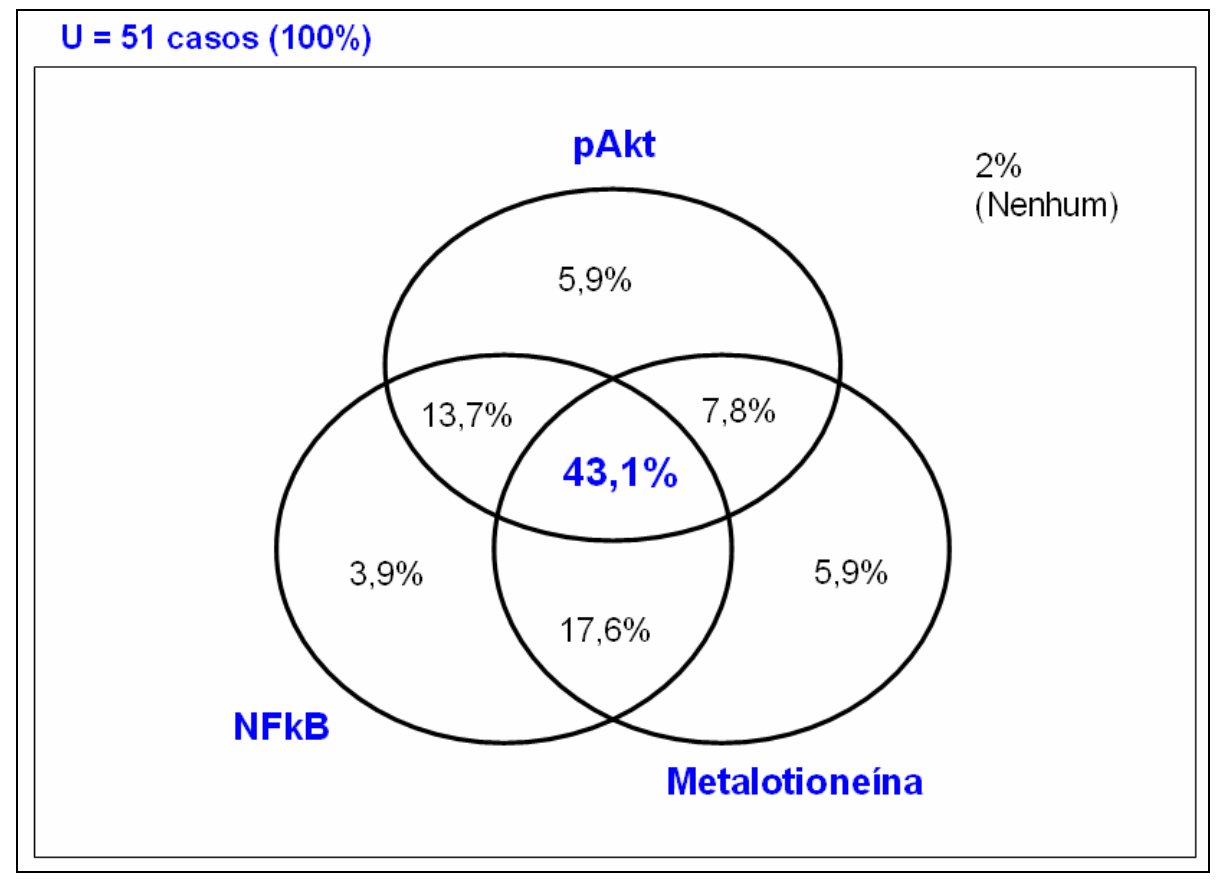

Gráfico 5.2 - Interação entre as proteínas

Significância estatística da distribuição das proteínas avaliadas pelo QuiQuadrado de Aderência, com correção de Yates, GL=1.

Tabela 5.2 - Distribuição das proteínas avaliadas pelo Qui-Quadrado de Aderência, com correção de Yates, GL=1.

\begin{tabular}{c|c|c|c}
\hline Proteínas & pAkt & Metalotioneína & NF-kB \\
\hline pAkt & --- & 0.6928 & 0.2334 \\
Metalo & & --- & 0.6096 \\
NF-kB & & & --- \\
\hline
\end{tabular}

A tabela 5.3 exibe o resultado do Qui-Quadrado de Aderência onde a distribuição das proporções dos testes das três proteínas não apresentou diferença significante. Somente a relação entre pAkt e metalotioneína foi avaliada como significativamente discordante, sendo esta avaliada pelo teste de McNemar, para amostras pareadas, o qual obteve p-valor $<0.0001$. 
Tabela 5.3 - Avaliação da discordância na ocorrência de proteínas

* Teste de McNemar

\begin{tabular}{c|c|c|c}
\hline McNemar & pAkt & Metalotioneína & NF-kB \\
\hline pAkt & --- & $<0.0001^{*}$ & 0.4807 \\
Metalo & & --- & 0.3036 \\
NF-kB & & & -- \\
\hline
\end{tabular}

\subsection{Análise das variáveis clínicas em função da sobrevida}

\subsubsection{Variável cirurgia}

Para avaliar a sobrevida dos pacientes desse estudo, tendo como base 0 tratamento cirúrgico realizado, foi aplicado o teste estatístico LogRank. O teste LogRank obteve $p$-valor $=0.0006$, o qual é altamente significante, portanto podemos concluir que o tempo de sobrevida varia em função da realização da cirurgia.

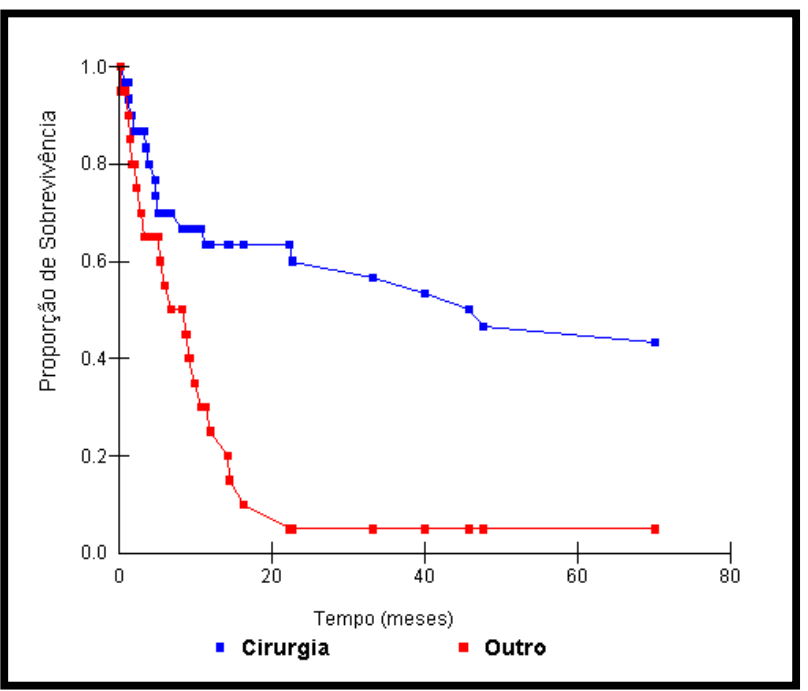

Observado $=18.0000$

$$
\begin{array}{cr}
\text { Esperado }= & 26.9330 \\
\text { Variância }(\mathrm{VL})= & 6.7329 \\
\text { Qui-quadrado }(\mathrm{WL})= & 11.8521 \\
\text { Graus de liberdade }= & 1 \\
(\mathrm{p})= & 0.0006^{*}
\end{array}
$$

$\mathrm{H}_{0}$ : O tempo de sobrevida com cirurgia e sem cirurgia é o mesmo. O tempo de sobrevida dos indivíduos que foram submetidos à cirurgia é diferente dos que foram tratados sem cirurgia. Nível de decisão: alfa $=0.05$ Conclusão: Rejeita-se $\mathrm{H}_{0}$.

Gráfico 5.3 - Proporção de sobrevida em função do tipo de terapia, com ou sem cirurgia 


\subsubsection{Variável Estadiamento}

A avaliação da sobrevida partindo-se do parâmetro estadiamento, o teste LogRank obteve p-valor $=0.4859$, o qual não é significante, portanto não temos evidências suficientes para afirmar a existência de associação entre os estádios e o tempo de sobrevida.

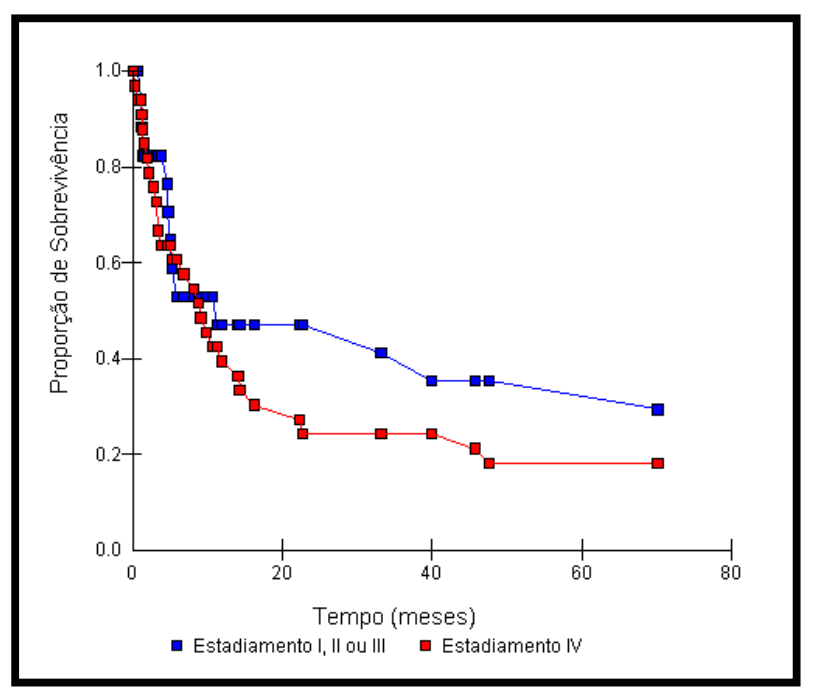

$$
\begin{array}{cr}
\text { Observado }= & 13.0000 \\
\text { Esperado }= & 15.1201 \\
\text { Variância }(\mathrm{VL})= & 9.2554 \\
\text { Qui-quadrado }(\mathrm{WL})= & 0.4856 \\
\text { Graus de liberdade }= & 1 \\
(\mathrm{p})= & 0.4859
\end{array}
$$

$\mathrm{H}_{0}$ : O tempo de sobrevida nos estádios

I, II e III é o mesmo que no estádio IV. $\mathrm{H}_{1}$ : O tempo de sobrevida nos estádios I, II e III é diferente do estádio IV. Nível de decisão: alfa $=0.05$

Gráfico 5.4 - Proporção de sobrevida em função do estadiamento

\subsubsection{Variável etilismo}

O teste LogRank também foi aplicado para interpretar a relação sobrevida etilismo. $O$ valor final foi de $p=0.0006$, o qual é altamente significante, portanto podemos afirmar que existe associação entre o consumo de bebida alcoólica e o tempo de sobrevida. Sendo o etilismo associado à menor sobrevida. 


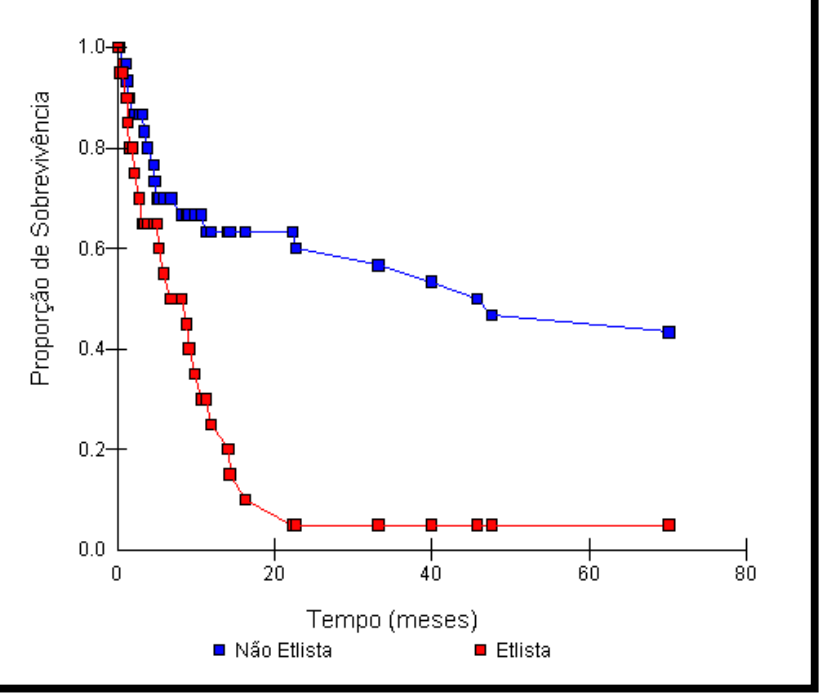

Observado $=18.0000$

Esperado $=26.9330$

Variância $(\mathrm{VL})=6.7329$

Qui-quadrado $(\mathrm{WL})=\quad 11.8521$

Graus de liberdade $=1$

$(p)=0.0006^{*}$

$\mathrm{H}_{0}$ : O histórico de consumo de álcool não interfere no tempo de sobrevida dos pacientes.

$\mathrm{H}_{1}$ : O histórico de consumo de álcool interfere no tempo de sobrevida dos pacientes.

Nível de decisão: alfa $=0.05$

Gráfico 5.5 - Proporção de sobrevida em função do consumo de álcool

\subsubsection{Variável idade $\geq 45$ anos}

O teste LogRank obteve p-valor $=0.2989$, o qual não é significante, portanto não temos evidências suficientes para afirmar que existe associação entre a idade $\geq$ 45 anos e o tempo de sobrevida.

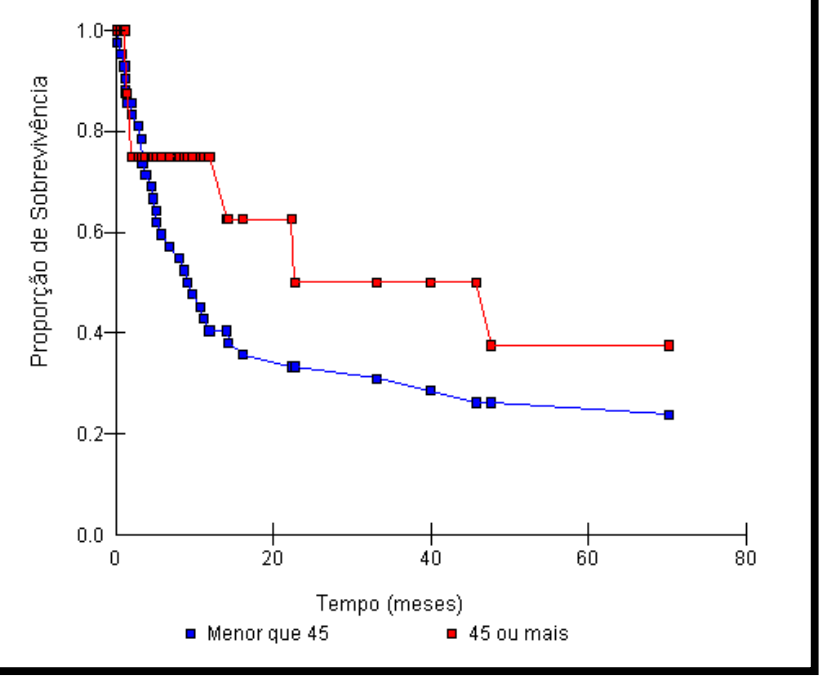

Observado $=33.0000$

Esperado $=30.4609$

Variância $(\mathrm{VL})=5.9755$ Qui-quadrado $(\mathrm{WL})=1.0789$

Graus de liberdade $=1$

$(p)=0.2989$

$\mathrm{H}_{0}:$ A idade $\geq 45$ anos não interfere no tempo de sobrevida.

$\mathrm{H}_{1}$ : $\mathrm{A}$ idade $\geq 45$ anos interfere no tempo de sobrevida. Nível de decisão: alfa $=0.05$

Gráfico 5.6- Proporção de sobrevida em função da idade 45 anos 
5.3.5 Variável localização (língua/assoalho)

De acordo com o teste LogRank ( $p$-valor $=0.1352)$ não temos evidências suficientes para afirmar que existe associação entre a localização da neoplasia e a sobrevida.

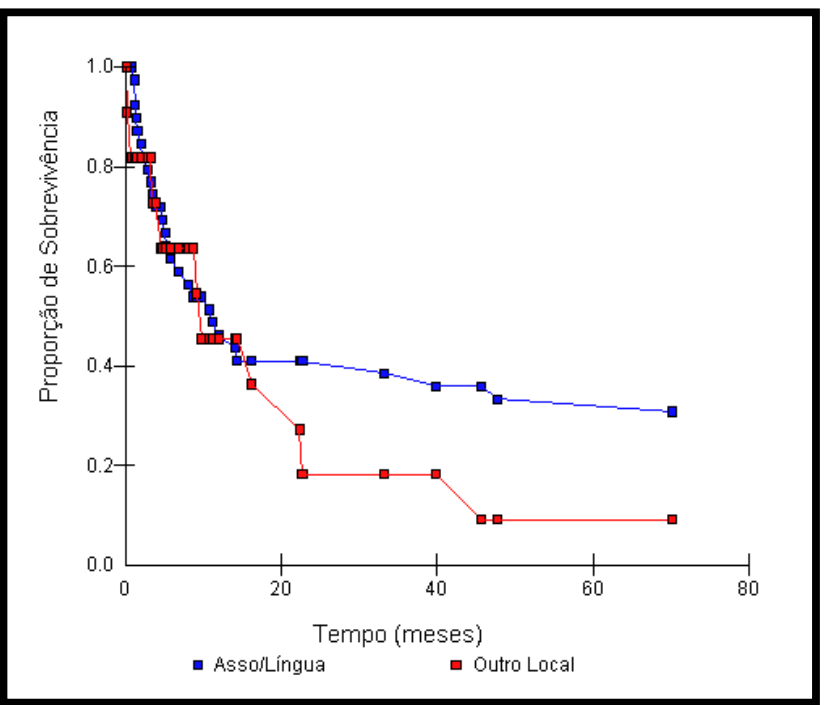

Observado $=27.0000$

Esperado $=30.6133$ Variância $(\mathrm{VL})=5.8501$ Qui-quadrado $(\mathrm{WL})=\quad 2.2317$

Graus de liberdade $=1$ $(p)=0.1352$ $\mathrm{H}_{0}$ : A localização da neoplasia (língua/assoalho) não interfere no tempo de sobrevida. $\mathrm{H}_{1}$ : A localização da neoplasia (língua/assoalho) interfere no tempo de sobrevida. Nível de decisão: alfa $=0.05$

Gráfico 5.7 - Proporção de sobrevida em função da localização da neoplasia

\subsubsection{Variável sexo}

Nas amostras desse estudo não houve associação entre o tempo de sobrevida e o sexo dos pacientes (LogRank $p=0.7083)$. 


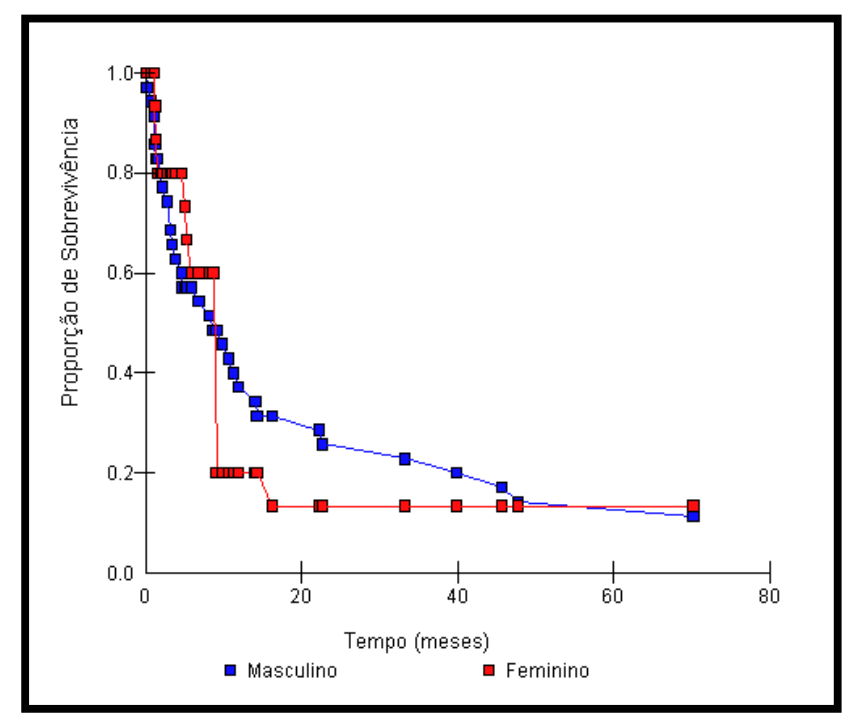

Observado $=31.0000$

Esperado $=32.1017$

Variância $(\mathrm{VL})=8.6722$ Qui-quadrado $(\mathrm{WL})=0.1400$

Graus de liberdade $=\quad 1$

$(p)=0.7083$

$\mathrm{H}_{0}$ : Não existe associação entre o sexo do paciente e o tempo de sobrevida.

$\mathrm{H}_{1}$ : Existe associação entre o sexo do paciente e o tempo de sobrevida.

Nível de decisão: alfa $=0.05$

Gráfico 5.8 - Proporção de sobrevida em função do sexo do paciente

5.3.7 Variável tabagismo

Nas 51 amostras deste estudo não houve correlação estatisticamente significante entre o tabagismo e a sobrevida (LogRank p-valor $=0.3148)$.

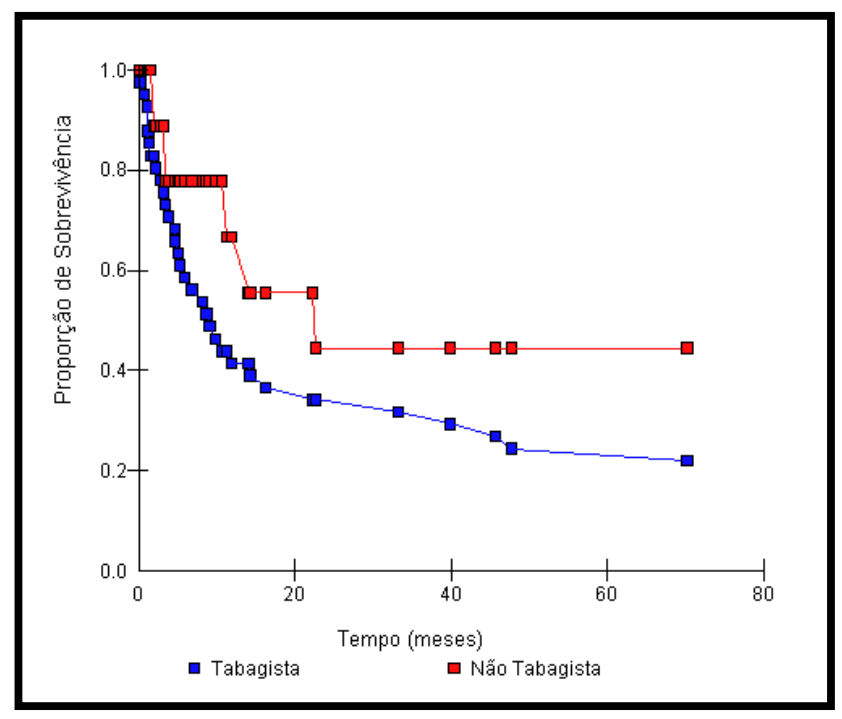

Observado $=32.0000$

Esperado $=29.4198$

Variância $(\mathrm{VL})=6.5877$

Qui-quadrado $(\mathrm{WL})=1.0106$

Graus de liberdade $=1$

$(p)=0.3148$

$\mathrm{H}_{0}$ : Não Existe associação entre o tabagismo e o tempo de sobrevida.

$\mathrm{H}_{1}$ : Existe associação entre $\mathrm{o}$ tabagismo e o tempo de sobrevida.

Nível de decisão: alfa $=0.05$

Gráfico 5.9 - Proporção de sobrevida em função do tabagismo 
5.4 Análise das proteínas pAkt, NF-kB e metalotioneína em relação à sobrevida

\subsubsection{Variável pAkt}

Trinta e seis amostras foram consideradas marcação positiva e quinze amostras foram consideradas marcação negativa. A maioria das amostras positivas exibiu marcação nuclear, havendo também marcação simultânea de núcleo e citoplasma (Figuras 5.1 e 5.2).

O teste LogRank obteve p-valor $=0.0298^{*}$, o qual é significante, portanto podemos afirmar que a expressão da proteína pAkt causa impacto no tempo de sobrevida (Gráfico 5.10).

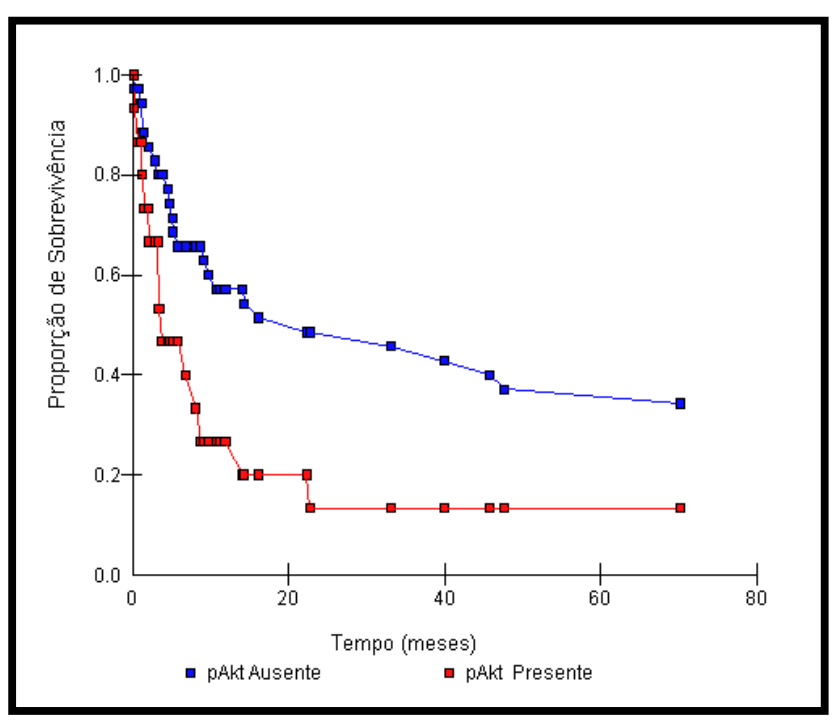

Observado $=25.0000$

Esperado $=30.3134$

Variância $(\mathrm{VL})=5.9795$

Qui-quadrado $(\mathrm{WL})=\quad 4.7214$

Graus de liberdade $=1$

$(p)=0.0298^{*}$

$\mathrm{H}_{0}$ : Não existe associação entre a presença da proteína pAkt e o tempo de sobrevida.

$\mathrm{H}_{1}$ : Existe associação entre a presenç

a da proteína pAkt e o tempo de sobrevida.

Nível de decisão: alfa $=0.05$

Gráfico 5.10 - Proporção de sobrevida em função da presença de pAkt 


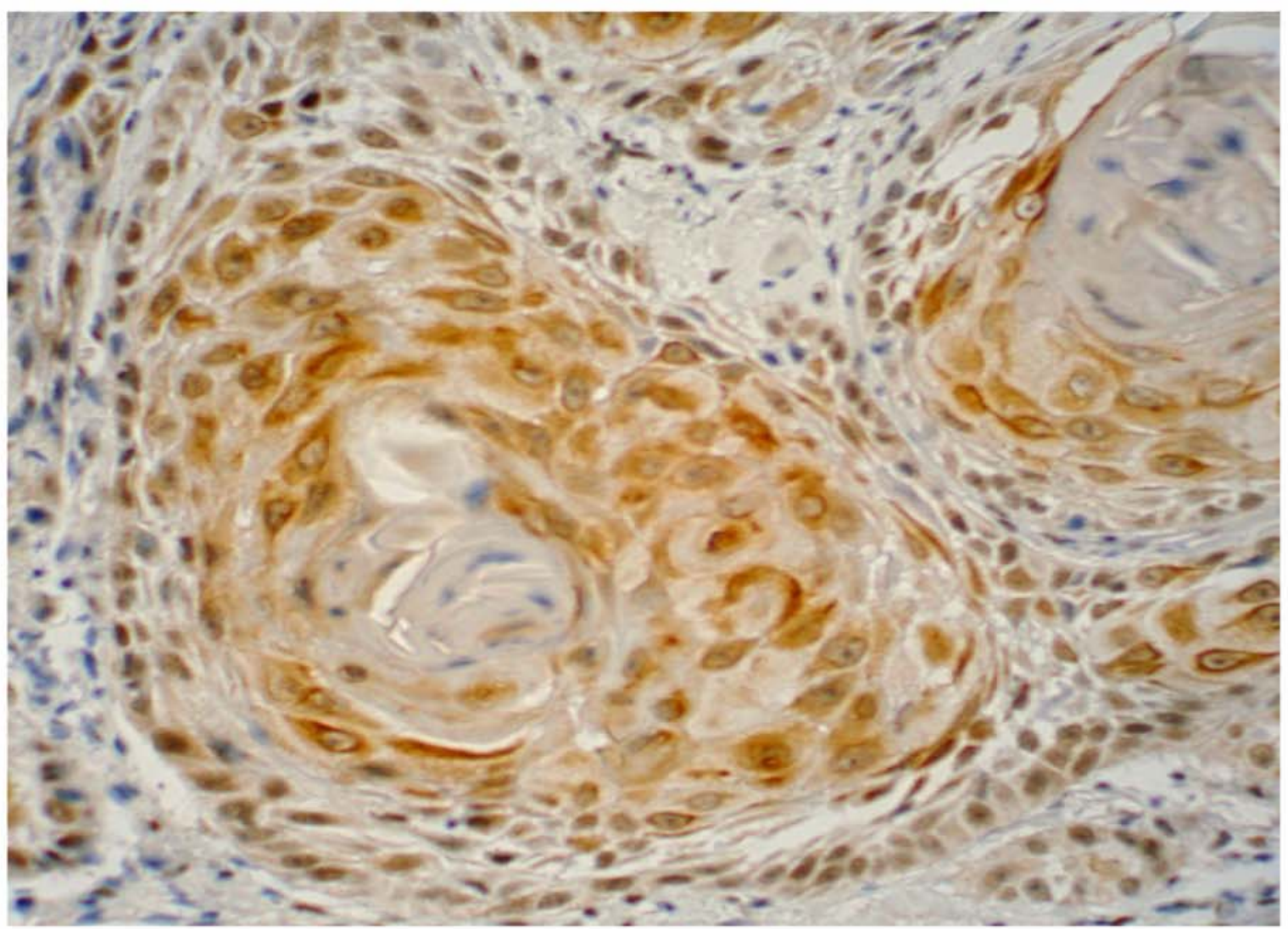

Figura 5.4.1.1 - Imunoexpressão da proteína pAkt (Streptavidina-biotina 400X).

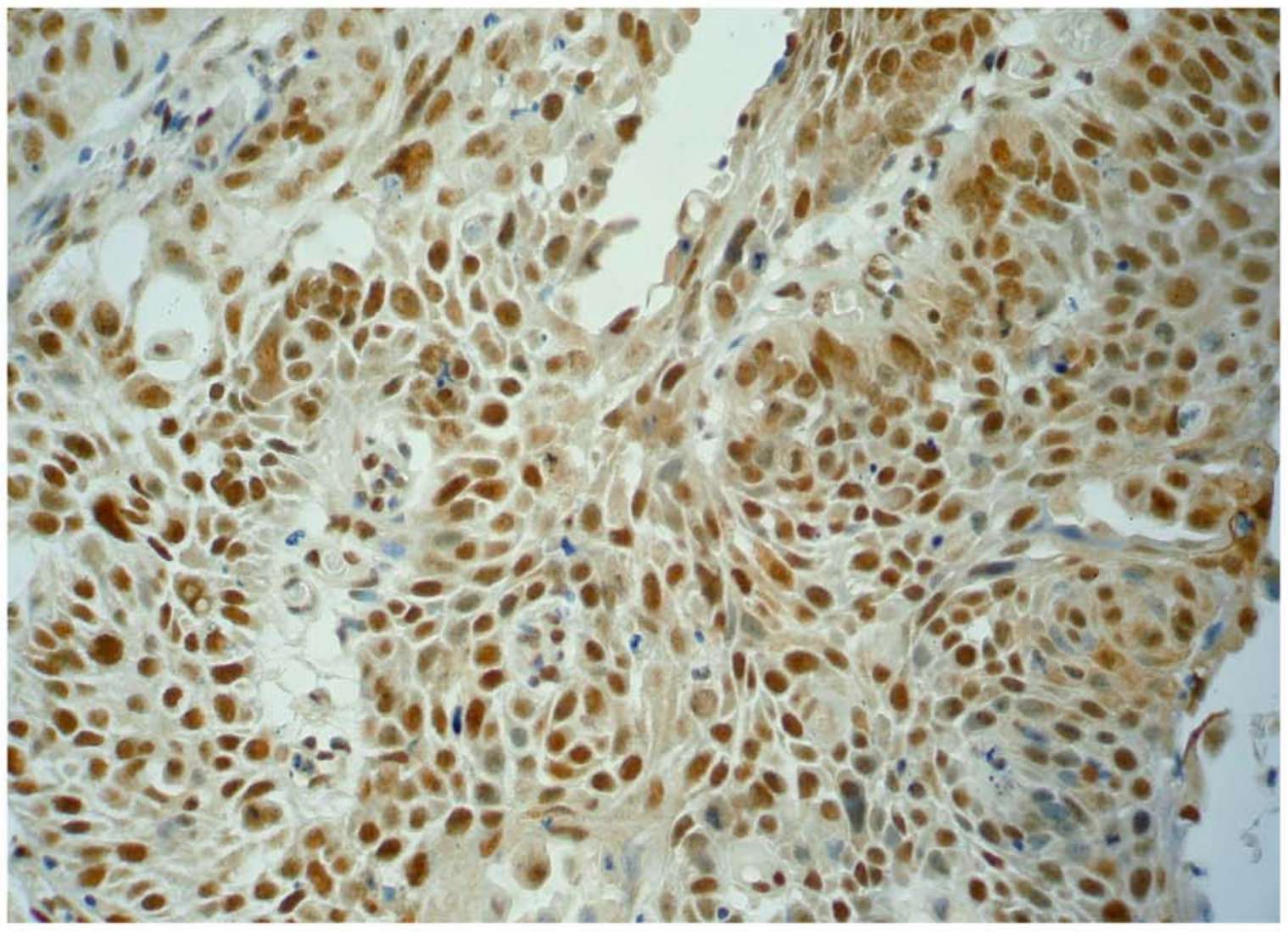

Figura 5.4.1.2 - Imunoexpressão da proteina pAkt (Streptavidina-biotina 200X). 


\subsubsection{Variável NF-kB}

A proteína NF-kB foi encontrada no citoplasma da maioria das células, porém algumas amostras apresentaram marcação nuclear focal (Figura 5.3). Em alguns campos observou-se marcação citoplasmática e nuclear ocorrendo simultaneamente (Figura 5.4). De acordo com o teste LogRank $(p=0.1817)$ não é possível afirmar influência da proteína NF-kB com o tempo de sobrevida.

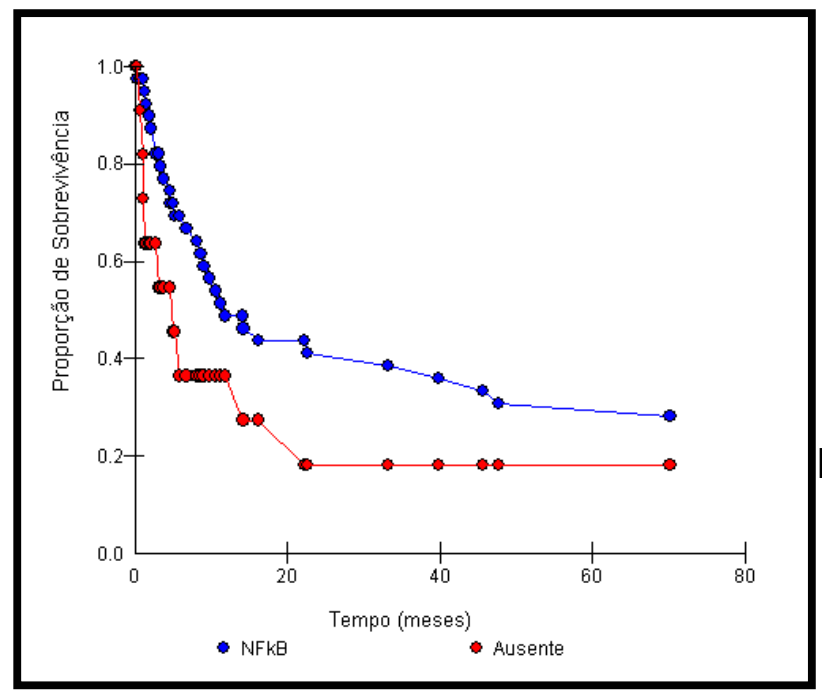

Observado $=29.0000$ Esperado $=31.9920$ Variância $(\mathrm{VL})=5.0189$ Qui-quadrado $(\mathrm{WL})=1.7836$ Graus de liberdade $=1$ $(p)=0.1817$ $\mathrm{H}_{0}$ : Não Existe associação entre presença de NF-kB e o tempo de sobrevida . $\mathrm{H}_{1}$ : Existe associação entre a presença de NF-kB e o tempo de sobrevida . Nível de decisão: alfa $=0.05$

Gráfico 5.11 - Proporção de sobrevida em função da presença de NF-kB 


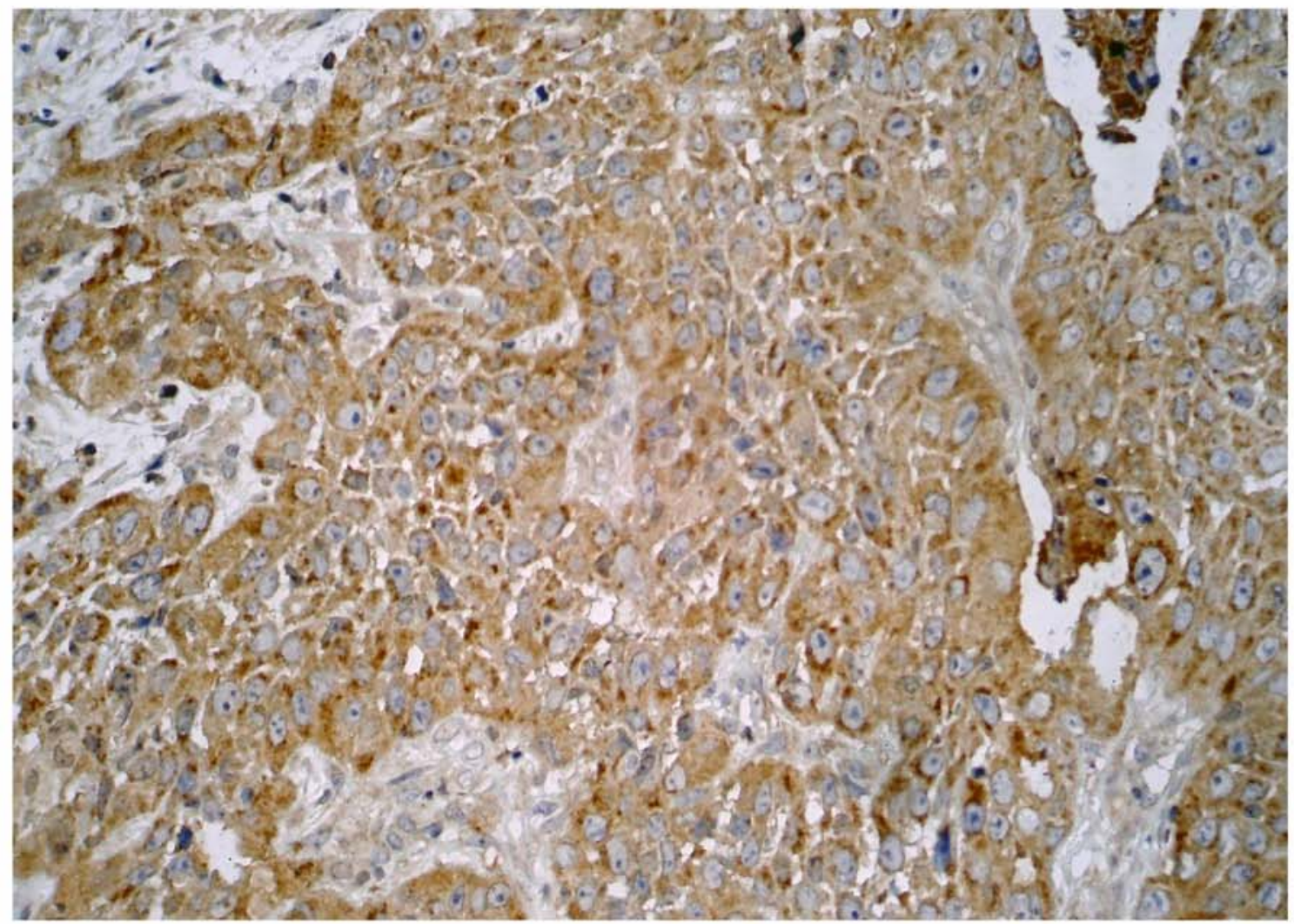

Figura 5.4.2.1 - Imunoexpressão da proteina NF-kB (Streptavidina-biotina 200X).

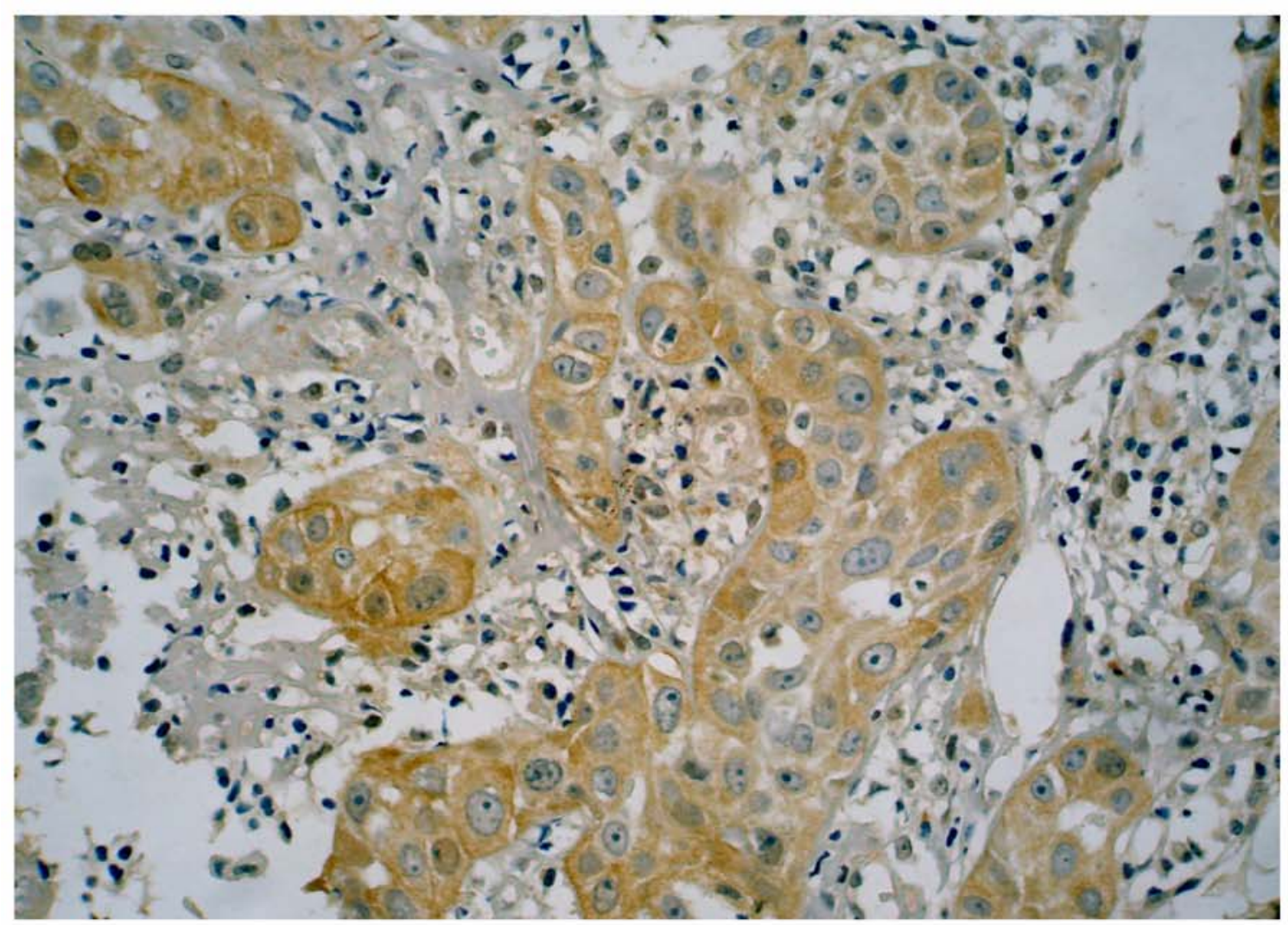

Figura 5.4.2.2 - Imunoexpressão da proteína NF-kB (Streptavidina-biotina 400X). 
5.4.3 Variável metalotioneína

Imunoreatividade para a proteína MT foi observada tanto no núcleo como no citoplasma e algumas vezes em ambos os compartimentos na mesma célula (Figuras 5.5 e 5.6).

O teste LogRank obteve $p$-valor $=0.0835$, o qual não é significante, portanto não temos evidências suficientes para afirmar que a presença de metalotioneína altera o tempo de sobrevida.

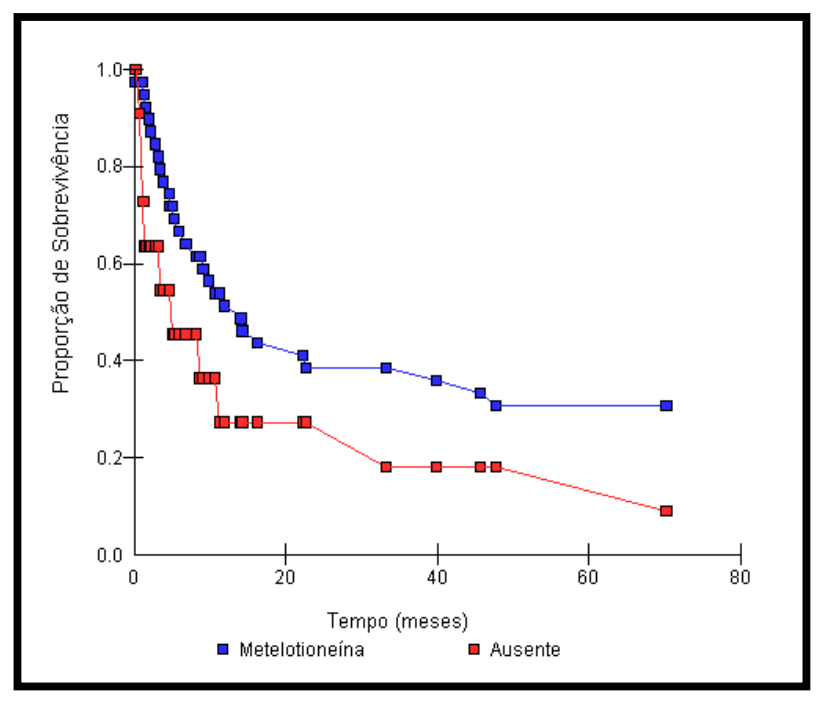

Observado $=28.0000$

Esperado $=31.8992$

Variância $(\mathrm{VL})=5.0772$

Qui-quadrado $(\mathrm{WL})=2.9945$

Graus de liberdade $=1$

$(p)=0.0835$

$\mathrm{H}_{0}$ : Não Existe associação entre a presença de Metalotioneína e o tempo de sobrevida. $\mathrm{H}_{1}$ : Existe associação entre a presença de Metalotioneína e a sobrevida.

Gráfico 5.12 - Proporção de sobrevida em função da presença de metalotioneína 


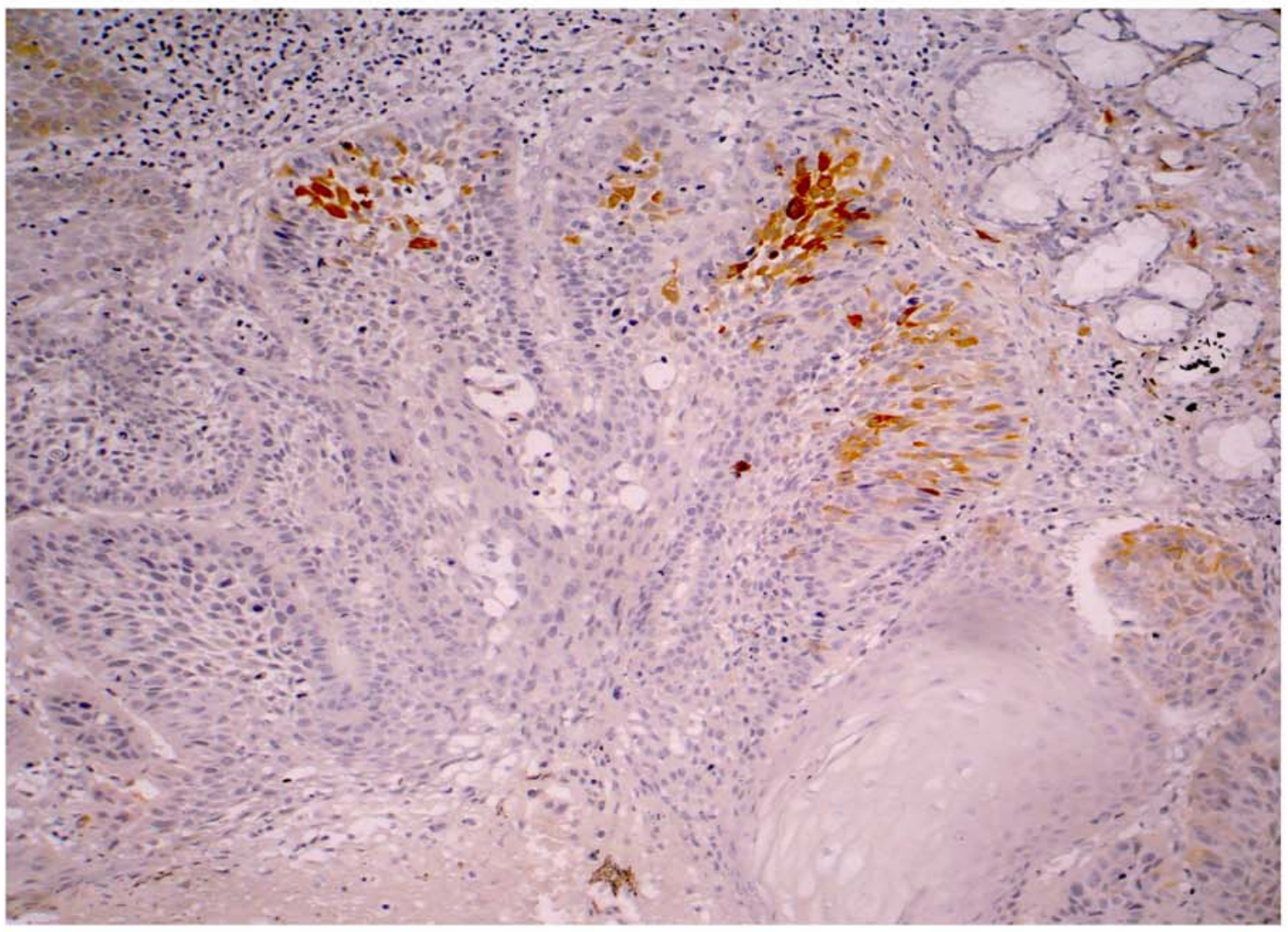

Figura 5.4.3.1 - Imunoexpressão da proteína metalotioneína (Streptavidina-biotina 200X).

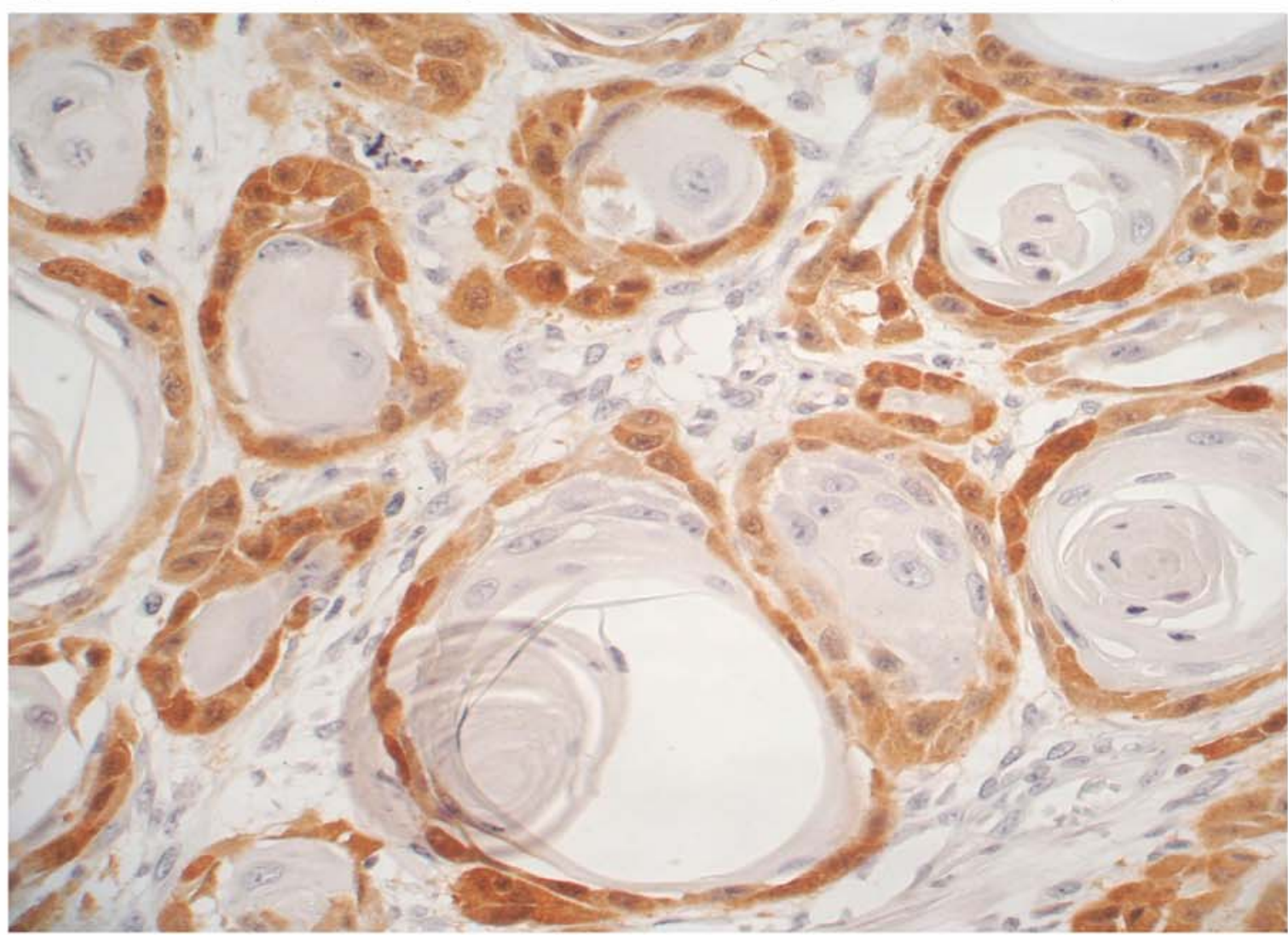

Figura 5.4.3.2 - Imunoexpressão da proteina metalotioneina (Streptavidina-biotina 400X). 


\subsection{Análise da curva de sobrevida}

O gráfico 5.13 exibe o tempo de sobrevida em meses dos pacientes pesquisados.

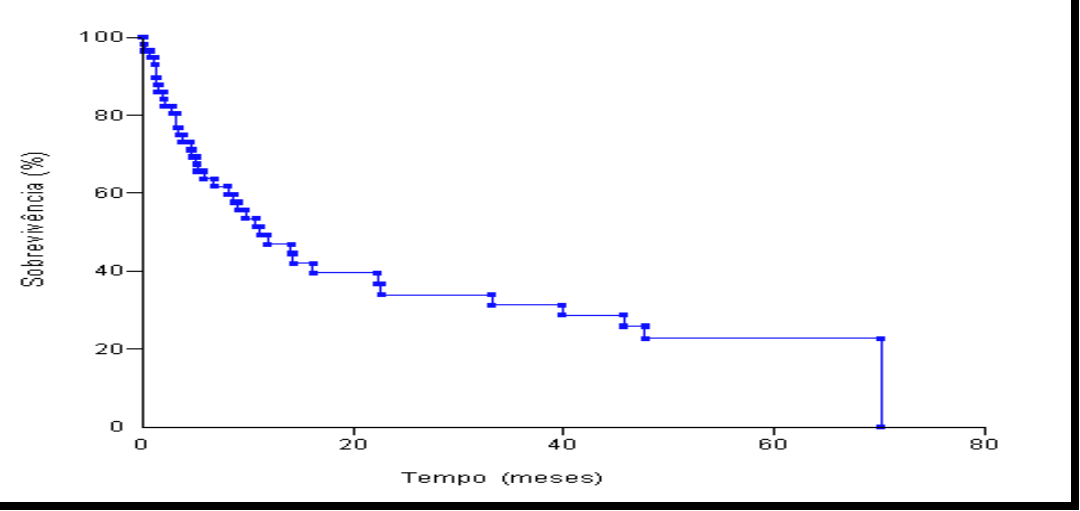

Gráfico 5.13 - Gráfico de Kaplan-Meyer da curva de sobrevida geral

A tabela 5.4 apresenta a distribuição da proporção de sobrevida e da taxa de risco em função do tempo (meses). Ela está apresentada no gráfico acima.

Tabela 5.4 - Distribuição da proporção de sobrevida e da taxa de risco em função do tempo

\begin{tabular}{|c|c|c|c|}
\hline Tempo & Prop. Sobrev. & Tx. Risco. & Risco Acm. \\
\hline 0.1 & 0.983 & 0.0175 & 0.0175 \\
\hline 0.2 & 0.965 & 0.0179 & 0.0353 \\
\hline 0.7 & 0.948 & 0.0183 & 0.0536 \\
\hline 1.1 & 0.93 & 0.0188 & 0.0724 \\
\hline 1.2 & 0.896 & 0.038 & 0.1103 \\
\hline 1.3 & 0.878 & 0.0201 & 0.1304 \\
\hline 1.5 & 0.86 & 0.0207 & 0.1511 \\
\hline 2 & 0.842 & 0.0213 & 0.1724 \\
\hline 2.1 & 0.823 & 0.0222 & 0.1945 \\
\hline 2.8 & 0.805 & 0.0228 & 0.2174 \\
\hline 3.2 & 0.768 & 0.0464 & 0.2638 \\
\hline 3.4 & 0.749 & 0.0249 & 0.2887 \\
\hline 3.8 & 0.73 & 0.0255 & 0.3142 \\
\hline 4.6 & 0.712 & 0.0259 & 0.3402 \\
\hline 4.7 & 0.693 & 0.0263 & 0.3665 \\
\hline 5.1 & 0.675 & 0.0269 & 0.3934 \\
\hline 5.2 & 0.656 & 0.0277 & 0.4211 \\
\hline 5.8 & 0.637 & 0.0294 & 0.4505 \\
\hline 6.8 & 0.618 & 0.0312 & 0.4817 \\
\hline 8.1 & 0.598 & 0.0331 & 0.5147 \\
\hline 8.7 & 0.577 & 0.035 & 0.5498 \\
\hline 9.1 & 0.556 & 0.0366 & 0.5864 \\
\hline 9.8 & 0.535 & 0.0386 & 0.625 \\
\hline 10.7 & 0.514 & 0.04 & 0.665 \\
\hline 11.2 & 0.493 & 0.0429 & 0.7079 \\
\hline 11.9 & 0.469 & 0.0482 & 0.7561 \\
\hline 14.1 & 0.445 & 0.0528 & 0.8089 \\
\hline 14.3 & 0.421 & 0.0569 & 0.8658 \\
\hline 16.2 & 0.395 & 0.0618 & 0.9276 \\
\hline 22.3 & 0.367 & 0.0734 & 1.0011 \\
\hline 22.7 & 0.34 & 0.0782 & 1.0793 \\
\hline 33.2 & 0.313 & 0.0822 & 1.1615 \\
\hline 39.9 & 0.287 & 0.0867 & 1.2482 \\
\hline 45.7 & 0.259 & 0.1023 & 1.3504 \\
\hline 47.7 & 0.228 & 0.1269 & 1.4773 \\
\hline 70.2 & 0 & 7.733 & 9.2103 \\
\hline
\end{tabular}




\subsection{Análise do modelo de risco proporcional de Cox}

O modelo de risco proporcional de Cox analisa a influência das variáveis que interferiram na sobrevida (cirurgia. pAkt e consumo de álcool).

O gráfico 5.14 é uma das saídas do Cox survival hazard, onde é apresentada a variável cirurgia $\left(p\right.$-valor $\left.=0.0223^{*}\right)$ a qual é significante dentro do contexto da análise multivariada onde é considerada a influência das outras duas variáveis que compõe o modelo: alcoolismo e pAkt.

Gráfico 5.14 - Cox survival hazard, variável cirurgia

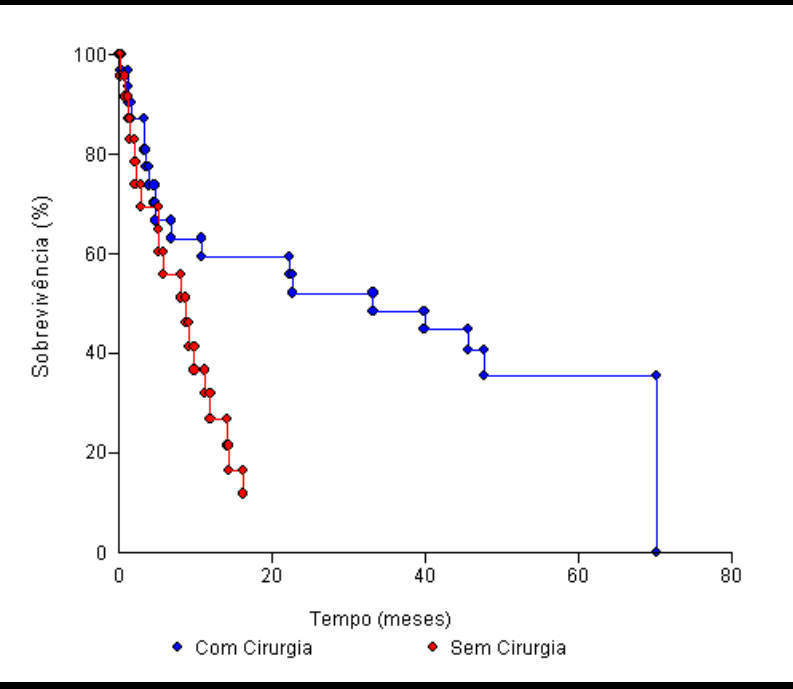

O gráfico 5.15 é outra das saídas do Cox survival hazard, onde é apresentada a variável pAkt $\left(p\right.$-valor $\left.=0.0419^{*}\right)$ a qual é significante dentro do contexto da análise multivariada onde é considerada a influência das outras duas variáveis que compõe o modelo: etilismo e cirurgia. 


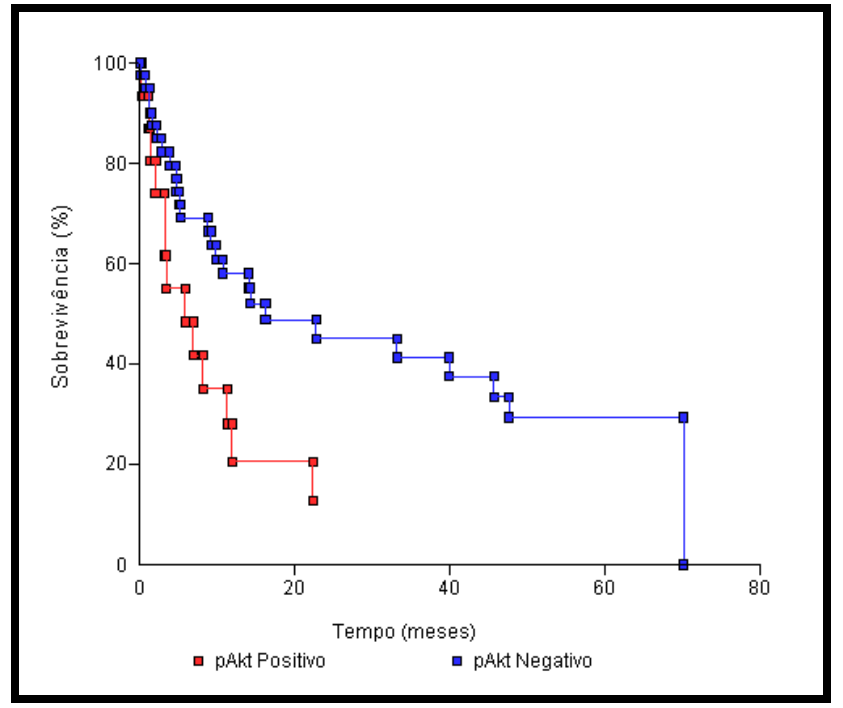

Gráfico 5.15 - Cox survival hazard pAkt

O gráfico, referente ao Cox survival hazard, exibe a variável etilismo ( $p$-valor = 0.5655) a qual não é significante dentro do contexto da análise multivariada onde é considerada a influência das outras duas variáveis que compõe o modelo: pAkt e cirurgia.

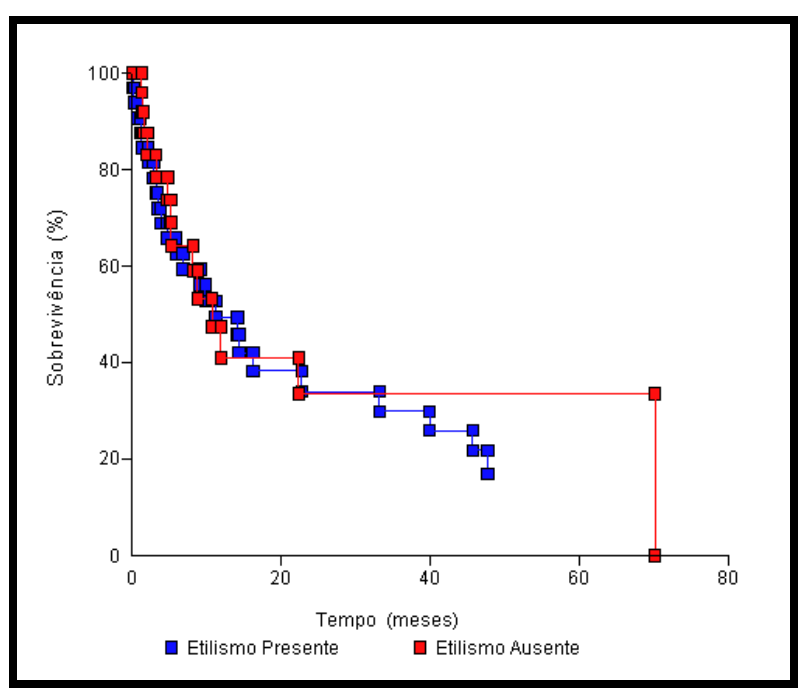

Gráfico 5.16 - Cox survival hazard, etilismo 


\subsection{Variáveis preditoras pelo modelo de Cox}

Taxa de risco para o etilismo, cirurgia e pAkt.

Tabela 5.5 - Variáveis preditoras pelo modelo de Cox

\begin{tabular}{l|c|c|c}
\hline & Etilismo & Cirurgia & pAkt \\
\hline B & 0.1986 & -0.7883 & 0.7157 \\
E. Padrão & 0.3456 & 0.3449 & 0.3517 \\
p-valor & 0.5655 & $0.0223^{*}$ & $0.0419^{*}$ \\
Tx. Risco & 1.2197 & 0.4546 & 2.0455 \\
IC 95\% (Tx. Risco) & $0.6196-2.4013$ & $0.2313-0.8937$ & $1.0267-4.0755$ \\
\hline
\end{tabular}

\subsection{Distribuição do tamanho do tumor $(T)$ conforme a presença das proteínas}

Foi aplicado o teste $U$ de Mann-Whitney.

O tamanho do tumor (T) não sofre alteração em função da presença de quaisquer das três proteínas, todas as proteínas obtiveram p-valor não significante.

Tabela 5.6 - Distribuição do tamanho do tumor $(T)$ conforme a presença das proteínas

\begin{tabular}{c|c|c|c}
\hline & pAkt & NF-kB & Metalotioneína \\
\hline & mediana (min, máx) & mediana (min, máx) & mediana (min, máx) \\
Positivo & $4(1,4)$ & $3.5(1,4)$ & $4(1,4)$ \\
Negativo & $3(1,4)$ & $4(1,4)$ & $3(2,4)$ \\
p-valor & 0.0862 & 0.8367 & 0.4824 \\
\hline
\end{tabular}




\subsection{Distribuição da recidiva conforme a presença de pAkt}

Não há evidências suficientes para afirmar que a ocorrência de recidiva sofre alguma alteração em função da ocorrência de pAkt ( $p$-valor $=0.6184$, Qui-Quadrado de Aderência e p-valor $=1.0000$, teste exato de Fisher).

Tabela 5.7 - Distribuição da recidiva conforme a presença de pAkt

\begin{tabular}{c|c|c|c|c}
\hline \multicolumn{3}{|c|}{ Recidiva } & \multicolumn{2}{c}{ Sem Recidiva } \\
\hline pAkt & $\mathrm{n}$ & $\%$ & $\mathrm{n}$ & $\%$ \\
Positivo & 6 & 75.0 & 30 & 69.8 \\
Negativo & 2 & 25.0 & 13 & 30.2 \\
Total & 8 & 100 & 43 & 100 \\
\hline
\end{tabular}

\subsection{Distribuição da recidiva conforme a presença de metalotioneína}

Não há evidências suficientes para afirmar que a ocorrência de recidiva sofre alguma alteração em função da ocorrência de metalotioneína ( $p$-valor $=0.0827$, QuiQuadrado de Aderência e p-valor $=0.4041$, teste exato de Fisher).

Tabela 5.8 - Distribuição da recidiva conforme a presença de metalotioneína

\begin{tabular}{l|c|c|c|c}
\hline \multicolumn{3}{c}{ Recidiva } & \multicolumn{2}{c}{ Sem Recidiva } \\
\hline Metalotioneína & $\mathrm{n}$ & $\%$ & $\mathrm{n}$ & $\%$ \\
Positivo & 5 & 62.5 & 33 & 76.7 \\
Negativo & 3 & 37.5 & 10 & 23.3 \\
Total & 8 & 100 & 43 & 100 \\
\hline
\end{tabular}




\subsection{Distribuição da recidiva conforme a presença de NF-kB}

Não há evidências suficientes para afirmar que a ocorrência de recidiva sofra alteração em função da ocorrência de NF-kB ( $p$-valor $=0.1043$, Qui-Quadrado de Aderência e p-valor $=0.6685$, Teste Exato de Fisher).

Tabela 5.9 - Distribuição da recidiva conforme a presença de NF-kB

\begin{tabular}{l|c|c|c|c}
\multicolumn{3}{|c|}{ Recidiva } & \multicolumn{2}{c}{ Sem Recidiva } \\
\hline NF-kB & $\mathrm{n}$ & $\%$ & $\mathrm{n}$ & $\%$ \\
Positivo & 7 & 87.5 & 33 & 76.7 \\
Negativo & 1 & 12.5 & 10 & 23.3 \\
Total & 8 & 100 & 43 & 100 \\
\hline
\end{tabular}

\subsection{Distribuição do tabagismo conforme a presença de pAkt}

Influência do consumo de tabaco na presença da proteína pAkt ( $\mathrm{p}$-valor = 0.6084, Qui-Quadrado de Aderência e p-valor = 0.9986, teste exato de Fisher).

Tabela 5.10 - Distribuição do tabagismo conforme a presença de pAkt

\begin{tabular}{l|c|c|c|c}
\multicolumn{4}{c}{ Fumantes } & \multicolumn{2}{c}{ Não Fumantes } \\
\hline pAkt & $\mathrm{n}$ & $\%$ & $\mathrm{n}$ & $\%$ \\
Positivo & 30 & 71.4 & 6 & 33.3 \\
Negativo & 12 & 28.6 & 3 & 100 \\
Total & 42 & 100 & 9 & \\
\hline
\end{tabular}

\subsection{Distribuição do tabagismo conforme a presença de NF-kB}

Influência do consumo de tabaco na presença da proteína NF-kB ( $p$-valor = 0.0820, Qui-Quadrado de Aderência e p-valor $=0.6630$, teste exato de Fisher). 
Tabela 5.11 - Distribuição do tabagismo conforme a presença de NF-kB

\begin{tabular}{l|c|c|c|c}
\hline \multicolumn{3}{|c|}{ Fumantes } & \multicolumn{2}{c}{ Não Fumantes } \\
\hline NF-kB & $\mathrm{n}$ & $\%$ & $\mathrm{n}$ & $\%$ \\
Positivo & 32 & 76.2 & 8 & 88.9 \\
Negativo & 10 & 23.8 & 1 & 11.1 \\
Total & 42 & 100 & 9 & 100 \\
\hline
\end{tabular}

\subsection{Distribuição do tabagismo conforme a presença de metalotioneína}

Influência do consumo de tabaco na presença da proteína metalotioneína ( $p$ valor $=0.2048$, Qui-Quadrado de Aderência e p-valor $=0.6760$, teste exato de Fisher).

Tabela 5.12 - Distribuição do tabagismo conforme a presença de metalotioneína

\begin{tabular}{l|c|c|c|c}
\multicolumn{4}{c}{ Fumantes } & Não Fumantes \\
\hline Metalotioneína & $\mathrm{n}$ & $\%$ & $\mathrm{n}$ & $\%$ \\
Positivo & 32 & 76.2 & 6 & 66.7 \\
Negativo & 10 & 23.8 & 3 & 33.3 \\
Total & 42 & 100 & 9 & 100 \\
\hline
\end{tabular}




\section{DISCUSSÃO}

A identificação de moléculas que estejam associadas à transformação maligna tem permitido identificar marcadores moleculares relacionados com estadiamento tumoral, com o curso clínico das doenças, assim como com o prognóstico. O estudo desses marcadores pode ajudar a encontrar meios de tratamento não cirúrgicos para os carcinomas epidermóides de boca, através da terapia gênica, ou pelo uso de quimioterápicos eficazes que atuem na via de sinalização a que essas proteínas pertençam (VORA et al., 2003).

O presente estudo avaliou a imunoexpressão das proteínas pAkt, metalotioneína e NF-kB em carcinomas de boca. Os experimentos foram conduzidos com a finalidade de verificar a associação dessas proteínas e de alguns dados clínicos (consumo de tabaco e álcool, tratamento cirúrgico, presença de recidiva, sexo, idade e localização) com a sobrevida em 51 pacientes com carcinomas epidermóides bucais.

Grande parte de nossa amostra constituiu-se de biópsias incisionais, realizadas com fins diagnósticos. É provável que algumas delas não sejam representativas da área mais profunda da lesão. Entretanto, conforme os resultados deste estudo e de trabalhos anteriores (BRYNE et al., 1992; BRYNE, 1998), a gradação de amostras colhidas por biópsia incisional a partir da área com pior padrão de invasão também é predictiva de prognóstico (ODELL et al., 1994), embora a mesma metodologia obtenha melhores resultados quando aplicada a espécimes cirúrgicos terapêuticos (ROLAND et al., 1992). 
A razão da escolha dessas proteínas, neste estudo, ocorreu em função delas possuírem interações entre si. A proteína pAkt concorre para a ativação da proteína NF-kB, possibilitando a transcrição de genes com atividade anti-apoptótica, próinflamatórias e de indutoras de proliferação (KWON et al., 2008; SHAH et al., 2005). Nesse sentido, as proteínas PI3K e Akt têm sido requeridas para ativação de NF-KB, induzida por TNFa e Inteleucina 1 (IL-1), através da fosforilação e ativação da subunidade p65. Ao lado disso, Romashkova e Makarov (1999) mostraram que o PDGF (PDGF- do inglês Platelet-derived growth factor) é capaz de ativar Ras que estimula a via PI3K/Akt. A proteína pAkt, posteriormente, é capaz de fosforilar IKK, liberando NF-kB da ação repressora de IkB no citoplasma. Assim, ficou definido que NF-kB é um alvo da via anti-apoptótica Ras/PI3K/Akt.

Recentemente, tem sido também mostrado que ativação da proteína Akt, estimulada por IL-1, ocasiona fosforilação da subunidade p50 de NF-KB (LI; STARK, 2002; RAVI; BEDI, 2004). Finalmente, Lee et al. (2005) sugerem que ativação de NF-kB aumenta a expressão de Akt, assim como Akt aumenta a expressão de NFkB em carcinomas gástricos, sugerindo haver, portanto, uma alça regulatória recíproca entre essas proteínas.

A vinculação da MT com NF-kB encontra-se bem estabelecida na literatura. Abdel-Mageed e Agrawal (1998) observaram uma interação física, em linhagens celulares de adenocarcinomas de mama, da proteína MT com a subunidade p50, do dímero p50/RelA de NF-kB, sugerindo que tal associação medeia positivamente os efeitos anti-apoptóticos da MT. Butcher et al. (2004), também sugeriram que as MT-1 e MT-2 regulam os níveis celulares e a atividade da subunidade p65 de NF-kB. A idéia da ativação e interação de NF-kB pela MT pode ser fortalecida pelo fato dessas duas proteínas compartilharem algumas propriedades: sobre-regulação durante o 
desenvolvimento, estímulos que aumentam suas expressões (TNF- $\alpha$, lipopolissacárides-LPS e IL-1), translocação para o núcleo após ativação ou indução, ambas possuem efeitos anti-apoptóticos e de resistência à drogas antineoplásicas, e finalmente porque tanto a ativação de NF-kB como a indução da expressão de MT ocorrem em regeneração tecidual após hepatectomia in vivo (ABDELL-MAGEED; AGRAWAL, 1998; KIM et al., 2003; TSUJIKAWA et al., 1994).

Em outro estudo foi demonstrado que a sobre-expressão de MT aumenta a ligação de NF-kB ao DNA (KANEKIYO et al., 2001). Kim et al. (2003) mostraram que o aumento da expressão de MT atenua o efeito inibitório do Zn sobre a atividade de NF-kB. Por outro lado Sakurai et al. (1999) demonstraram que a MT pode funcionar como um regulador negativo da atividade de NF-kB, um vez que a MT inibiu a degradação de $\mathrm{IkBa}$ induzida por TNF, assim como inibiu a expressão de genes dependentes da ação de NF-kB.

Em relação à proteína pAkt o resultado de nosso estudo exibiu que a imunoexpressão da proteína pAkt está associada a um menor tempo de sobrevida nos pacientes avaliados. A imunomarcação da proteína pAkt foi observada tanto no citoplasma como núcleo das células dos carcinomas epidermóides investigados. O papel de pAkt no citoplasma de indutor de proliferação e de bloqueio de apoptose já está bem estabelecido na literatura. Dentre os principais efeitos pAkt no citoplasma estão a inibição da atividade da proteína pró-apopótica BAD e caspase 9, o aumento da atividade de NF-kB, a indução da transcrição do fator E2F, a retenção das proteínas p27, p21 e do fator de transcrição FKHRL1 no citoplasma e a translocação de Mdm2 e ß-catenina para o núcleo. Esses efeitos, em conjunto, contribuem para a proliferação celular e não permitem que a célula caminhe para a morte celular programada (BRUNET et al., 1999; DATTA et al., 1997; DATTA; BRUNET; 
GREENBERG, 1999; HAH et al., 2003; MAYO; DONNER, 2002; SÖDERLUNG; PÉREZ-TENÓTIO; STÄL, 2005; VESTEY et al., 2005; ZHANG et al., 2007).

A atribuição da proteína Akt no núcleo, entretanto, ainda não foi amplamente demonstrada. Kikani, Dong e Liu (2005) reportaram que Akt pode ser fosforilado pela proteína PDK1 no núcleo (ANDJELKOVIC et al., 1997). A translocação, para o núcleo após a ativação de Akt na membrana plasmática, ocorre em aproximadamente 30 minutos, evidenciando a existência de substratos para Akt no compartimento nuclear (DATTA; BRUNET; GREENBERG, 1999).

Trotman et al. (2006) reportaram que a proteína supressora tumoral PML (do inglês promyelocytic leukemia) inibe a carcinogênese através da desfosforilação e inativação de pAkt localizada no compartimento nuclear. Os autores inferiram que a redução progressiva de $\mathrm{PML}$ permite tanto o bloqueio da transcrição mediada por FOXO3a da proteína pró-apoptótica Bim, como interrupção da transcrição da proteína inibidora do ciclo celular $\mathrm{p} 27^{\mathrm{Kip} 1}$. Oportuno lembrar que o fator de transcrição FOXO3 é fosforilado por pAkt no núcleo, inativado e exportado para o citoplasma. Outro estudo relatou que pAkt localizado no núcleo participa dos efeitos anti-apoptóticos promovidos por NGF (do inglês nerve growth factor) ao unir-se com Ebp1 fosforilado por PKC-ס. O complexo pAkt/Ebp1 formado inibe a ação de CAD, um inibidor de fragmentação do DNA dependente da DNase apoptótica. O aumento dos efeitos anti-apoptóticos de Ebp1 ligado a Akt, independe da atividade quinase de Akt, diferente do que ocorre com pAkt citoplasmático (AHN et al., 2006). Recentemente Kwon et al. (2008) contribuíram para o esclarecimento do papel de Akt no núcleo ao mostrarem que Akt1 após ligar-se com Ki-ras, transloca-se para o núcleo, onde se liga ao heterodímero p65/RelA de NF-KB determinando o aumento da atividade transcricional de NF-kB. 
Por outro lado o estudo de Madddika et al. (2007) concluiu que pAkt no núcleo desenvolve uma resposta indutora de apoptose. Nessa pesquisa, esses autores mostraram haver uma interação física da proteína apoptina com a subunidade p85 de PI3K, estimulando, desse modo, sua ativação. Posteriormente, a proteína Akt fosforilada transloca-se para o núcleo junto com a proteína apoptina, realizando efeitos pró-apoptóticos. Apoptina é uma proteína rica em prolina codificada pelo gen VP3 de CAV (do inglês vírus anemia infectious chicken) que produz efeitos próapoptóticos em células de neoplasias malignas, mas não patrocina a morte celular programada em células não neoplásicas. Em células cancerígenas apoptina migra para o núcleo, através dos poros na membrana nuclear, e promove a morte celular através da ativação da via de morte mitocondrial (liberação de citocromo C e ativação de caspase 3). Tal processo é dependente de Nur77, uma proteína nuclear, que é exportada para o citoplasma, após ser estimulada por apoptina, e que, posteriormente, liga-se a membrana mitocondrial (MADDIKA et al., 2006). A proteína Akt é capaz de fosforilar Nur77 em seu domínio de ligação do DNA, diminuindo sua ligação ao DNA e estimulando sua translocação para o citoplasma (MADDIKA et al., 2006; PERKASKY et al., 2001).

Diante dos resultados obtidos da associação da proteína pAkt com a sobrevida, nos carcinomas epidermóides investigados, parece-nos lícito sugerir que a proteína pAkt possui, no núcleo, uma função muito mais bloqueadora do que de indutora da morte celular programada. Seria interessante, entretanto, pesquisar a participação das proteínas Nur77 e apoptina nos carcinomas epidermóides de boca.

A relação de pAkt com o tabaco, principal agente etiológico vinculado ao carcinoma epidermóide de boca, tem sido estudada. Nessa linha de raciocínio, convém mencionar o estudo de West et al. (2003) que comprovaram, após análise 
das células epiteliais neoplásicas de pulmão e do trato respiratório, que a nicotina e o NNK (do inglês 4-methylnitrosamino-1-3pyridil-1 butanone), dois carcinógenos do tabaco, conduziram a ativação de Akt e de alguns de seus alvos intracelulares como GSK-3, p70S6K, 4EBP-1 e FKHR. Além disso, indução de lesões pré-malignas no pulmão e de hiperplasia no epitélio dos brônquios em porcos, submetidos à inalação de fumaça de cigarro, foi acompanhada por um aumento da ativação de Akt (FIALA et al., 2005).

Os nAChRs (do inglês- nicotinic acetylcholine receptors) são uma classe de receptores responsáveis pela regulação da proliferação e diferenciação de queratinócitos bucais. Tais receptores podem ser formados por heterodímeros compostos por várias subunidades ( $\alpha 3, \alpha 5, \alpha 7, \alpha 9, \beta 2$ e $\beta 5)$. O repertório de subtipos de nAChRs se altera durante o processo de diferenciação dos queratinócitos no epitélio. A nicotina promove, em queratinócitos bucais, um aumento da subunidade $\alpha 7$ do nAChRs, patrocinando, assim um aumento do influxo de Ca para o interior da célula, o que conduz a ativação de PI3K e de ras e consequentemente aumento de Akt estimulado (ARREDONDO et al., 2008). Em conjunto esses dados sugerem que Akt poder ser estimulado pelos carcinógenos do tabaco em queratinócitos bucais.

Um dos possíveis mecanismos utilizados pela proteína pAkt para redução da sobrevida dos pacientes com carcinoma epidermóide de boca pode estar vinculado à transição epitélio-mesênquima patrocinada por pAkt. A transição epitéliomesênquima é um importante processo no desenvolvimento e na carcinogênese humana. Nesse processo, as células epiteliais adquirem propriedades semelhantes a fibroblastos, mostram reduzida adesão celular e aumento da motilidade. Linhagens de carcinomas epidermóides de língua que expressam constitutivamente 
pAkt sofreram a transição epitélio-mesênquima, e são caracterizadas por baixos níveis de marcadores epiteliais como desmoplaquina, E-caderina e $\beta$-catenina, e aumento de marcadores mesenquimais como a vimentina. Tais células perdem a morfologia epitelial e adicionalmente passam a diminuir sua atividade transcricional de E-caderina. Ao lado disso, as células epiteliais passam a exibir adesão reduzida, aumento da motilidade sobre superfícies cobertas com fibronectina e aumento da invasividade em animais (GRILLE et al., 2003; LIM et al., 2004). Transição epitéliomesênquima coordenada por Akt pode conferir a motilidade requerida para invasão e metástase.

Estimulação de AKT ocasiona também potencialização da transcrição de alguns genes como SNAIL que reprimem a transcrição de E-caderina. Então além de internalizar E-caderina, Akt reprime a transcrição de E-caderina (GRILLE et al., 2003). Oportuno mencionar, a relação de pAkt com Anoikis. Anoikis é um termo reservado para apoptose induzida pelo desgarramento celular. Esta forma de apoptose desempenha um papel fundamental na prevenção de invasão e metástase em carcinomas. Expressão de Ras ativado, em certas células, permite inibição da Anoikis via ativação de Akt (VAZQUEZ; SELLERS, 2000). Esses dados sugerem que futuras terapias baseadas na inibição de Akt podem complementar tratamentos convencionais e levar ao controle da invasão celular e metástase dos carcinomas epidermóides. Lim et al. (2005) após avaliarem, através de imunoistoquímica 81 amostras de carcinoma epidermóide de boca, observaram que a sobre-expressão de pAkt correlacionou-se com baixa expressão de E-caderina, sugerindo a participação de pAkt na transição epitélio-mesênquima em carcinomas epidermóides de boca.

Ainda sob a participação de pAkt sobre a motilidade e invasividade das células neoplásicas, Toker e Yoeli-Lerner (2006) relataram que a proteína Akt1 
bloqueou a invasão de células de carcinoma de mama em matrigel e Akt2 induziu a invasão e que em ambas as isoformas de Akt promoveram seus efeitos através do bloqueio e estímulo, respectivamente, do fator de transcrição NFAT (do inglês nuclear factor activated T cells).

Várias pesquisas foram desenvolvidas com a finalidade de vincular a proteína Akt à carcinogênese da região de cabeça e pescoço. Mandal et al. (2006) e Amornphimoltham et al. (2004) mostraram que Akt apresenta expressão aumentada em HNSCC (do inglês squamous cell carcinoma of head and neck) e Gupta et al. (2002) sugeriram a participação do receptor EGF e da ativação da via PI3K/Akt na radioresistência de carcinomas de cabeça e pescoço. Os autores inferiram que a fosforilação de Akt via PI3K pode ser usado como um marcador prognóstico para resposta à radioterapia. Já foi estabelecido, também, que a Akt estimula a expressão da metaloproteinase 9 em linhagens celulares de HNSCC, o qual desempenha um papel importante na invasão e metástase de neoplasias malignas (KAOMONGKOLGIT et al., 2007). Sasabe et al. (2005) relataram que o fator de transcrição HIF-1 (do inglês hypoxia-inducible factor-1), o qual promove angiogênese e inibição da apoptose em condições de hipóxia, previne a apoptose através da ativação de Akt em linhagens de carcinomas epidermóides de boca.

A maioria das amostras de carcinomas epidermóides de boca utilizadas nesta pesquisa pertencia a pacientes em estádios III e IV. Nessa linha de pensamento, convém mencionar o trabalho de Kozaki et al. (2006) que reportou a presença de mutação no gene PIK3CA, o qual codifica a subunidade catalítica 110-kDa de PI3K, especialmente em carcinomas de boca que se encontravam em estádio IV. Esses resultados associados à influência de pAkt na sobrevida, obtido neste estudo, 
sugere que mutação na via PI3K/Akt deve ser um evento tardio no processo de carcinogênese bucal.

Em linhagens de células de carcinomas epidermóides de boca, o controle da apoptose, via Fas-L, requer ativação da via de sinalização PI3K/Akt. A proteína Akt ativada induz o aumento da expressão de c-FLIP (do inglês cellular FLICE-inhibitoty protein), proteína que inibe apoptose por bloqueio da ação do complexo FADD/caspase 8/ DISC (IWASE et al., 2007; KONDO et al., 2006). Sundelin et al. (1997) não evidenciaram a imunoexpressão do receptor Fas em células epiteliais da mucosa bucal, porém comprovaram a expressão desse receptor em todos os 24 casos de carcinomas epidermóides de língua pesquisados. Além disso, já está demonstrado, em carcinomas epidermóides bucais, que a expressão de Fas está vinculada à resistência a quimio e radioterapia, aos índices de recorrência, ao estadiamento e a sobrevida (GULER et al., 2005; MURAKI et al., 2000).

Dois recentes estudos conduzidos por Lim et al. (2005) e Massarelli et al. (2005) também relataram o valor da expressão de pAkt como marcador prognóstico em carcinomas epidermóides de boca, e Yu et al. (2007) demonstraram que a expressão de pAkt associa-se a pobres resultados clínicos (maior recorrência e menor sobrevida) em carcinomas epidermóides da região bucal e faringiana.

Por aumentar a expressão de genes que estimulam a proliferação e sobrevida, além de promover angiogênese e metástase, a via NF-kB desempenha um papel chave na iniciação e manutenção do fenótipo oncogênico (YAMAMOTO; GAYNOR, 2004). Além disso, ativação da via NF-kB após quimio e radioterapia, permite indução de inibidores da apoptose, resultando em diminuída morte celular programada (ROJO et al., 2004; YAMAMOTO; GAYNOR, 2004). 
Embora a proteína NF-kB não tenha mostrado associação estatisticamente significante com um pior prognóstico, nos casos levantados em nossa pesquisa, a expressão de NF-kB foi associada a expressão da proteína pAkt, corroborando com os resultados encontrados por Fenic et al. (2007). Esses resultados nos permitem inferir que a proteína pAkt pode controlar a morte celular programada e estimular proliferação utilizando-se, também, da ativação da proteína NF-kB, via fosforilação de IKK. Tal asseveração encontra sustentação em alguns estudos como o de Tsurutani et al. (2005) que mostrou que alguns componentes do tabaco (nicotina e NNK) induziram proliferação celular, em carcinomas de pulmão, através da ativação de Akt e inibição da apoptose dependente de NF-kB. O Tabaco, também, mostrou estimular as células epiteliais das vias aéreas, assim como de células do sistema imune, a liberarem citocinas pró-inflamatórias como IL-1 $\beta$, que por sua vez ativam a transcrição da via NF-kB permitindo a regulação de vários genes relacionados à inflamação, incluindo IL-6 (do inglês interleukin-6), IL-8 e COX2 (CAMPA et al., 2004).

Nessa linha de pensamento, o estudo conduzido por Tamatani et al. (2001) constatou um aumento na expressão de IKK, em linhagens de células de carcinomas epidermóides da região de cabeça e pescoço, quando comparada com expressão desse complexo protéico observada em células normais. Oportuno, também, mencionar a pesquisa de Nakayama et al. (2001) que reportou um aumento na expressão da subunidade p65 de NF-kB, além de IKKa e de Akt em carcinomas epidermóides de boca, quando comparadas com o epitélio normal e com áreas displásicas. Finalmente Santhi et al. (2006) relataram que a expressão citoplasmática e nuclear de NF-kB aumentou com a progressão histológica após 
análise do tecido normal, leucoplásico e em cortes que exibiam carcinomas epidermóides de boca.

Outros estudos têm confirmado a participação da via Akt/NF-kB na indução dos efeitos anti-apoptóticos em carcinomas epidermóides de boca. Sandra et al. (2002) encontraram, em linhagens de células de carcinomas epidermóides da região de cabeça e pescoço, uma ligação da fosforilação de Akt /degradação de IkB com a inibição da apoptose induzida via TNF (do inglês tumour necrosis factor) e Chen, Fribley e Wang (2002) informaram que inibição da ação de NF-kB sensibilizou as células de carcinomas epidermóides de boca à apoptose via TNF. Adicionalmente, esses autores informaram, que o bloqueio de NF-kB aumentou a ativação de caspase 8 e caspase 3 via TNF.

Convém aclarar que os efeitos anti-apoptóticos patrocinados por NF-kB podem ocorrer através da regulação da transcrição do receptor e da molécula sinalizadora Fas (CHAN; BARTOS; OWEN-SCHAUB, 1999; KASIBHATLA; GENESTIER; GREEN, 1999), cuja relação com carcinoma epidermóide de boca e com a proteína Akt foi discutida anteriormente. Acrescenta-se, ainda, que Fujita et al. (2004) relataram uma elevação da expressão de NF-kB em células de carcinoma epidermóide de boca submetidas a ação do ácido okadaico, substância conhecida por aumentar a expressão de Fas-L e do receptor Fas.

A proteína NF-kB pode patrocinar efeitos anti-apoptóticos por outros caminhos, revisado em Barkett e Gilmore (1999). Nessa direção, convém analisar, em carcinomas epidermóides bucais, a expressão dos alvos downstream de NF-kB que executam os efeitos anti-apoptóticos como as proteínas FLIP (do inglês FLICElike inhibitory protein), TRAF2 e TRAF6, das proteínas IAPs (do inglês Inhibitors of apoptosis) e de BAX (DOLCET et al., 2005; RAVI; BEDI, 2004; SCHUCHMANN; 
GALLE, 2002). O mapeamento dessas proteínas auxiliará na busca por mais quimioterápicos que sejam efetivos no tratamento dos carcinomas epidermóides albergados na boca.

Já o envolvimento da proteína NF-kB com a motilidade e invasão em carcinomas epidermóides bucais foi avaliado por lkebe et al. (2004). Esses pesquisadores constataram que fibroblastos do estroma de carcinomas epidermóides bucais aumentaram a indução de metaloproteinase 9 , motilidade celular e a ativação de NF-kB. Em outra pesquisa Bindhu et al. (2006) também encontraram um aumento da expressão da atividade de metaloproteinase 9 correlacionada com o aumento da expressão de NF-kB na progressão histológica, após analisarem lesões leucoplásicas e de carcinomas epidermóides de boca, sugerindo um papel de NF-kB sobre a ativação de gelatinases durante a transformação maligna da mucosa bucal. Finalmente, Takamune et al. (2008) demonstraram, em linhagens de células de carcinomas epidermóides bucais, que TNFa induziu a ativação, por clivagem, da enzima ADAM-17 (do inglês disintegrin and metalloprotease domain) de maneira dependente de NF-kB e o uso de inibidores de ADAM-17 suprimiu a invasão induzida por TNFa nas células neoplásicas investigadas. Os autores sugeriram também que ADAM-17 promove invasão por clivar a proteína CD44, uma molécula de adesão de superfície o qual se liga ao ácido hialurônico, assim como realiza uma variedade de funções celulares como migração, proliferação e apoptose.

Já está estabelecido, também, na literatura a interação existente entre NF-kB e a proteína p53. Antagonismo das funções de transcrição que ocorre entre p53 e NF-kB envolve competição com co-ativadores como p300 e CBP (do inglês CREBbinding protein). Além disso, a proteína p53 reprime a expressão de $\mathrm{Bcl}-3$, um co- 
ativador transcricional da subunidade p52 de NF-kB. Ao lado dessa asseveração, a ativação de NF-KB mediada por IKK2 tem mostrado proteger células de apoptose induzida por dano no DNA, através do aumento dos níveis de Mdm2 (DOLCET et al., 2005; PERKINS, 2004; RAVI; BEDI, 2004).

Acrescido aos efeitos de controle da morte celular programada, NF-kB pode estimular a proliferação celular. NF-KB promove progressão do ciclo celular por regular a expressão de vários genes envolvidos na maquinaria do ciclo celular como as ciclinas D1, D2 e D3, além de c-myc e c-mycb. Expressão de ciclina D1 induzida por NF-kB parece ser o elemento chave no desenvolvimento de glândulas mamárias e carcinogênese de mama (AGGARWAL, 2004; DOLCET et al., 2005; KUMAR et al., 2004; RAVI; BEDI, 2004; YAMAMOTO; GAYNOR, 2004). Além disso, NF-kB induz a expressão de cicloxigenase-2 (COX2), cuja expressão é importante para o crescimento neoplásico, como observado em carcinomas de cólon, uma vez que COX-2 induz a expressão de alguns fatores angiogênicos (VEGF, FGF, PDGF, TGF$\beta$ ) e de seus receptores na superfície das células endoteliais (DOLCET et al., 2005; PERKINS, 2004; RAVI; BEDI, 2004; YAMAMOTO; GAYNOR, 2004).

Esses dados, analisados em conjunto, permitem-nos inferir que quimioterápicos que atuem no controle da ativação de NF-kB podem ser úteis no tratamento de carcinomas epidermóides da região de cabeça e pescoço. Inúmeras comprovações dessa afirmação têm sido exibidas na literatura. Vários estudos mostraram que muitas drogas antineoplásicas, em carcinomas epidermóides bucais, atuam inibindo a invasão local, a metástase para os nódulos linfáticos regionais, o controle da angiogênese através da supressão da atividade de NF-kB (BEPPU; IKEBE; SHIRASUNA, 2002; HARADA et al., 2007; LEE et al., 2007; TAKADA et al., 
2004; TAMATANI et al., 2007; TANIGUCHI et al., 2005; WAES et al., 2005; YAO et al., 2006; YAO et al., 2007).

O controle transcricional da indução de MT e mudanças em sua localização nuclear/citoplasmática durante proliferação e diferenciação celular sugerem que alterados níveis de MT podem ser esperados em situações onde há crescimento anormal, como no carcinoma (CHERIAN; JAYASURYA; BAY, 2003). A metalotioneína é uma proteína de localização principalmente citoplasmática em tecidos adultos. Embora não tenha sido identificado um local de ligação da MT ao DNA, sua transição para o núcleo ocorre sob certas condições de proliferação e diferenciação celulares (ABDEL-MAGEED; AGRAWAL, 1998; CHERIAN; JAYASURYA; BAY, 2003).

A imunoexpressão da proteína MT foi observada tanto no núcleo como no citoplasma das células dos carcinomas epidermóides investigados, neste estudo, assemelhando-se aos modelos encontrados em neoplasias malignas humanas de outros tecidos (THEOCHARIS et al., 2004). Cherian, Jayasurya e Bay (2003), em estudo de revisão, comentam que a translocação da MT para o compartimento nuclear durante a fase proliferativa (G1-S) do ciclo celular em neoplasias humanas suporta o papel de doadora de $\mathrm{Zn}$ realizado pela MT durante o crescimento neoplásico.

Um padrão de marcação em mosaico para a proteína MT foi observado nos carcinomas epidermóides estudados, com células fortemente imunomarcadas em algumas áreas, enquanto outros campos, na mesma lâmina, mostravam-se negativos. Acreditamos que esse padrão em mosaico pode ser fruto das diferenças fenotípicas celulares adquiridas durante a progressão neoplásica. 
Nos carcinomas epidermóides bem diferenciados, somente as células neoplásicas localizadas na periferia das ilhas tumorais foram marcadas, enquanto as células situadas centralmente permaneceram negativas. Quando havia presença de pérolas de queratina somente as camadas celulares basais e parabasais mostravam-se reativas. Para Sundelin et al. (1997) a marcação periférica da MT reproduz o padrão de marcação encontrado no epitélio normal e pode ajudar a desviar essas células da morte celular programada. O padrão de imunomarcação observado neste estudo foi semelhante ao encontrado por Cardoso et al. (2002).

A análise da expressão da proteína MT não promoveu resultados estatisticamente significantes quando associado à sobrevida dos pacientes com carcinomas epidermóides envolvidos neste estudo. Os resultados obtidos neste estudo não concordaram com os revelados pela pesquisa conduzida por Cardoso et al. (2002) que encontraram relação estatisticamente significante da MT com a sobrevida, ao analisarem a imunomarcação da MT em 60 carcinomas epidermóides de boca. Os resultados conflitantes podem estar associados à metodologia empregada. Cardoso et al. (2002) realizaram a contagem de 500 células e consideraram o caso como positivo quando havia $76 \%$ de imunoreatividade entre as células analisadas. O padrão em mosaico de marcação, comentado anteriormente, dificulta, em nosso entendimento, a escolha dos campos a serem contados. Esse fato pode ter contribuído para as discordantes conclusões. Assim, todos os 60 casos da pesquisa de Cardoso et al. (2002) foram considerados positivos, já a presente pesquisa encontrou 17 lâminas negativas das 51 pesquisadas.

Um dos mais importantes problemas na quimioterapia do carcinoma epidermóide é a resistência adquirida às drogas, e o mecanismo que possivelmente contribui para este fenômeno é o seqüestro de agentes alcalinizantes pela MT. 
Entretanto, dados obtidos de muitos trabalhos indicam que a resistência a quimioterapia mostrada em diferentes tipos de neoplasias não pode ser explicada por uma única via (THEOCHARIS et al., 2004).

É bem conhecido o papel da MT em ligar-se a radicais livres e a outros possíveis agentes citotóxicos. Após radioterapia, células neoplásicas produzem espécies reativas derivadas do oxigênio, moléculas que são úteis ao tratamento devido sua genotoxicidade (CHERIAN; JAYASURYA; BAY, 2003; CROMPTON, 1998; THEOCHARIS et al., 2004). Alguns quimioterápicos induzem similar mecanismo ou causam dano celular direto por conterem metais pesados. Em função das características bioquímicas da MT, espécies reativas do oxigênio e metais pesados podem se ligar as MT, tendo bloqueadas, assim, suas funções de injúria celular e conseqüente apoptose (CHERIAN; JAYASURYA; BAY, 2003; KONDO et al., 1995; THEOCHARIS et al., 2004). Nakano et al. (2003) relataram que as isoformas MTI e MTIII foram induzidas após tratamento com o quimioterápico Cisplatina, podendo desempenhar um importante papel na resistência à Cisplatina em carcinomas epidermóides de língua.

Em nosso estudo, a relação entre pAkt e MT foi avaliada como significantemente discordante, o que supõe que pAkt e metalotioneína realizam o controle de apoptose sem interação direta entre si. Um mecanismo que se poderia hipotetizar seria uma relação indireta de pAkt com a MT via NF-kB. Tal possibilidade se sustenta nos resultados estatísticos que indicaram que as três proteínas (pAkt, NF-kB e MT) apresentaram concordância entre si. A interação de NF-kB com a MT é necessária, no compartimento nuclear, para os efeitos de transcrição patrocinados por NF-kB e pAkt possui capacidade de inativar os repressores citoplasmáticos de NF-kB. Essas assertivas mostram que tanto pAkt como MT concorrem para ativação 
de NF-kB. Corroborando com essas afirmações nossos resultados mostraram que NF-kB apresentou expressão concordante com a expressão de MT, sugerindo um papel para MT na ativação de NF-kB nos carcinomas epidermóides pesquisados.

Por outro lado, MT poderia exercer seus efeitos anti-apoptóticos, em carcinomas epidermóides bucais, através do bloqueio da ação da proteína p53. Douglas-Jones et al. (1997) sugeriram que MT poderia remover Zn de p53, bloqueando sua atividade indutora de morte celular programada e Ostrakhovitch et al. (2006) demonstraram, em cultura de células de carcinomas de mama, uma interação entre MT1 e p53, sugerindo que a co-expressão de MT1 e p53 pode estar envolvida na regulação da apoptose nessas células. Finalmente, já foi demonstrado que combinada deficiência de zinco e da proteína p53 permite extrema sensibilidade à transformação maligna utilizando 4NQO (do inglês 4- nitroquinoline 1-oxide) em baixas concentrações em um modelo experimental de carcinogênese bucal realizado em camundongos (FONG; JIANG; FARBER, 2006).

Nesta pesquisa, a variável clínica cirurgia se mostrou associada a um maior tempo de sobrevida. Um estudo recente conduzido por Lung et al. (2007) corrobora os nossos resultados, mostrando que o tratamento que apresenta melhores resultados, para o carcinoma epidermóide nos estádios precoces (I e II), é o cirúrgico aplicado isoladamente e nos estádios avançados (III e IV) o tratamento cirúrgico combinado à radio e/ou à quimioterapia.

O consumo de álcool também mostrou interferir na sobrevida dos pacientes avaliados neste estudo. O etilismo associado ao tabagismo constitui o maior fator etiológico do carcinoma epidermóide bucal, sendo que o risco aumenta proporcionalmente à quantidade consumida (LEWIN et al., 1998; MCCAFFREY et al., 2007). O álcool aumenta a permeabilidade da mucosa bucal humana, em 
pequeno espaço de tempo, facilitando, assim, a penetração dos carcinógenos do tabaco (HOWIE et al., 2001). Hindle et al. (2000) em um estudo retrospectivo, também, associaram o aumento na incidência e da mortalidade dos carcinomas epidermóides bucais ao consumo de álcool, mais do que ao consumo de tabaco.

Considerável controvérsia existe na literatura sobre os pacientes considerados jovens que apresentam carcinoma epidermóide de boca. A discussão começa com a idade a ser estipulada para pacientes considerados jovens. Alguns autores determinam a idade limite como sendo de 40 anos (IYPE et al., 2001; SASAKI et al., 2005; SIRIWARDENA et al., 2006; VARGAS et al., 2000) enquanto outros determinam 45 anos (GOLDSTEIN; IRISH, 2005). Outro ponto polêmico diz respeito ao comportamento da neoplasia nesses pacientes, havendo relatos na literatura que mostram um curso mais agressivo para pacientes considerados jovens (VARGAS et al., 2000), enquanto outros estudos não relatam diferenças no prognóstico (GOLDSTEIN; IRISH, 2005; SASAKI et al., 2005; SIRIWARDENA et al., 2006). A porcentagem de pacientes jovens em várias partes do mundo varia em torno de 5 a $6 \%$ e o sítio mais acometido é a língua (GOLDSTEIN; IRISH, 2005; SIRIWARDENA et al., 2006). Em nosso estudo, consideramos pacientes com idade até 45 anos como jovem, por ser essa a idade mais adotada na literatura. Não houve diferença estatisticamente significante na sobrevida entre os dois grupos de pacientes. A língua foi o sítio mais acometido nos pacientes considerados jovens. Importante ressaltar a elevada taxa $(15,7 \%)$ de pacientes considerados jovens encontrada em nossa pesquisa quando comparado aos índices relatados em outras regiões do mundo. Não conseguimos identificar fatores que conduziriam a um aumento na incidência de carcinomas epidermóides de boca em pacientes considerados jovens. 


\section{CONCLUSÕES}

Após concluídas as reações de imunoistoquímica e a avaliação dos resultados conclui-se que:

3.1 Houve correlação estatisticamente significante entre a imunoexpressão da proteína pAkt e a sobrevida nos casos de carcinomas epidermóides investigados.

3.2 Houve correlação estatisticamente significante entre o consumo de álcool e a sobrevida dos pacientes com carcinomas epidermóides pesquisados.

3.3 Houve correlação estatisticamente significante entre o tratamento cirúrgico e a sobrevida dos casos de carcinomas epidermóides estudados.

3.4 O aumento da imunoexpressão da proteína pAkt associou-se a um aumento na expressão das proteínas metalotioneína e NF-kB. 


\section{REFERÊNCIAS ${ }^{1}$}

Abdel-Mageed AB, Agrawal KC. Activation of nuclear factor kB: potential role in metallothionein-mediated mitogenic response. Cancer Res 1998;58:2335-8.

Adams JM, Cory S. The bcl-2 protein family: arbiters of cell survival. Science 1998;28:1322-6.

Aggarwal BB. Nuclear factor-kB: the enemy within. Cancer Cell 2004;6:203-8.

Ahn J, Liu X, Liu Z, Pereira L, Cheng D. Nuclear Akt associates with PKCphosphorylated Ebp1, preventing DNA fragmentation by inhibition of caspasesactivated DNase. EMBO J 2006;25:2083-95.

Amornphimoltham P, Sriuranpong V, Patel V, Benavides F, Conti CJ, Vimutil S, et al. Persistent activaction of the Akt pathway in head and neck squamous cell carcinoma: a Potential target for UCN-01. Clin Cancer Res 2004;10:429-37.

Andjelkovic M, Alessi DR, Meier R, Fernandez A, Lamb NJC, French M, et al. Role of translocation in the activation and function of protein kinase $\mathrm{B}$. J Biol Chem 1997;272(50):31515-24.

Antunes JLF, Biazevic MGH, Araujo ME, Tomita NE, Chinellato LEM, Narvou PC, et al. Trends and spatial distribuition of oral cancer mortality in São Paulo, Brazil, 19801998. Oral Oncol 2001;37:345-50.

Arboleda MJ, Lyons JF, Kabbinavar FF, Bray MR, Snow BE, Sawyer BD, et al. Overexpression of Akt2/protein kinase $B \beta$ leads to up-regulation of $\beta 1$ integrins, increased invasion, and metastasis of human breast and ovarian cancer cells. Cancer Res 2003;63:196-206.

Arredondo J, Chernyavsky Al, Jolkovsky DL, Pinkerton KE, Grando SA. Receptormediated tobacco toxicity: acceleration of sequential expression of $\alpha 5$ and $\alpha 7$ nicotinic receptor subunits in oral keratinocytes exposed to cigarette smoke. FASEB J 2008;22:1-13.

\footnotetext{
${ }^{1}$ De acordo com estilo Vancouver. Abreviatura de periódicos segundo base de dados MEDLINE.
} 
Ayres M, Ayres Jr, Ayres DL, Santos AAS (2008). Bioestat Versão 5.0. Sociedade Civil Mamirauá, MCT - CNPq. Belém, Pará, Brasil.

Barkett M, Gilmore TD. Control of apoptosis by Rel/NF-kB transcription factors. Oncogenese 1999;18:6910-24.

Beppu M, Ikebe T, Shirasuna K. The inhibitoty effects of immunosuppressive factors, dexamethasone and interleukin-4, on NF-KB-mediated protease production by oral cancer. Biochim Biophys Acta 2002;1586:11-22.

Beyersmann D, Haase $H$. Functions of zinc in signaling, proliferation and differentiation of mammalian cells. Bio Metals 2001;14:331-41.

Bindhu OS, Ramadas K, Sebastian P, Pillai MR, Path FRC. High expression levels of nuclear factor kappa $B$ and gelatinases in the tumorigenesis of oral squamous cell carcinoma. Head Neck 2006;28:916-25.

Blackhall FH, Pintilie M, Michael M, Leighl N, Feld R, Canto MT, et al. Expression and prognostic significance of kit, protein kinase in patients with small cell lung cancer. Clin Cancer Res 2003;9:2241-7.

Blagosklonny MV. Are p27 and p21 cytoplasmatic oncoproteins? Cell Cycle 2002;1(6):391-3.

Brognard J, Clark AS, Ni Y, Dennis PA. Akt/Protein Kinase B is constitutively active in non-small cell lung cancer cells and promotes cellular survivaland resistance to chemotherapy and radiation. Cancer Res 2001;61:3986-97.

Brunet A, Bonni A, Zigmond MJ, Lin MZ, Juo P, Hu LS, et al. Akt promotes cell survival by phosphorylating and inhibiting a forkhead transcription factor. Cell 1999;96:857-68.

Bryne M. Is the invasive front of an oral carcinoma the most important area for prognostic? Oral Dis 1998;4:70-7.

Bryne M, Koppang HS, Lilleng R, Kjaerhein A. Malignancy grading of the deep invasive margins of oral squamous cell carcinomas has high prognostic value. $J$ Pathol 1992;166:375-81. 
Butcher HL, Kennette WA, Collins O, Zalups RK, Koropatnick J. Methallotionein mediates the level and activity of nuclear factor kB in murine fibroblasts. J Pharmacol Exp Therap 2004;310:589-98.

Campa D, Zienolddiny S, Maggini V, Skaug V, Haugen A, Canzian F. Association of a common polymorphism in the cyclooxygenase 2 gene with risk of non-small cell lung cancer. Carcinogenesis 2004;25(2):229-35.

Canto MT, Devesa SS. Oral cavity and pharynx cancer incidence rates in the United States. Oral Oncol 2002;38:610-7.

Cao $\mathrm{Y}$, Karin M. NFkB in mammmary gland development and breast cancer. J Mammmary Gland Biol Neop 2003;8(2):215- 23.

Cardone HM, Roy N, Stennicke HR, Salvesen GS, Franke TF, Stanbridge E, et al. Regulation of cell death protease caspase- 9 by phosphorilation. Science 1998;282:1318-21.

Cardoso SV, Barbosa HM, Candellori IM, Loyola AM, Aguiar MC. Prognostic impacto of metallothionein on oral squamous cell carcinoma. Virchows Arch 2002;441:174-8.

Chadha KS, Khoury T, Yu J, Black JD, Gibbs JF, Kuvshinoff BW, et al. Activated Akt and Erk expression and survival after surgery in pancreatic carcinoma. Ann Surg Oncol 2006;13(7):933-9.

Chan $\mathrm{H}$, Bartos DP, Owen-Schaub LB. Activation-dependent transcriptional regulation of the human fas promoter requires NF-kB p50-p65 recruitment. Mol Cell Biol 1999;19:2098-108.

Chen S, Fribley A, Wang CY. Potentiation of tumor necrosis factor-mediated apoptosis of oral squamous cell carcinoma cells by adenovirus-mediated gene transfer of NF-kB inhibitor. Res Rep 2002;81:98-102.

Cherian MG, Jayasurya A, Bay $\mathrm{BH}$. Metallothioneins in human tumors and potential roles in carcinogenesis. Mutat Res 2003;533:201-9.

Cherian MG, Kang YJ. Metallothionein and liver cell regeneration. Exp Biol Med 2006;231:138-44. 
Chin D, Boyle GM, Williams RM, Fergusson K, Pandeya N, Pedley J, et al. Novel markers for poor prognostic in head and neck cancer. Int J Cancer 2005;113:789-97.

Clark AS, West K, Streicher S, Dennis PA. Constituitve and inducible Akt activity promotes resistance to chemotherapy, Trastuzumab, or Tamoxifen in breast cancer cells. Mol Cancer Therap 2002;1:707-17.

Crompton NEA. Programmed cellular response in radiation oncology- basic and translational studies. Acta Oncol 1998;37:1-49.

Dai DL, Martinka M, Gang L. Prognostic significance of activated Akt expression in melanoma: a clinicopathologic study of 292 cases. J Clin Oncol 2005;23:1473-82.

Datta SR, Brunet A, Greenberg ME. Cellular survival: a play in three Akts. Genes Develop 1999;13:2905-27.

Datta SR, Dudek H, Tao X, Master S, Fu H, Gotoh Y, et al. Akt phosphorylation of BAD couples survival signals to the cell-intrinsic death machinery. Cell 1997;91(17):231-41.

David O, Jett J, LeBaeau H, Dy G, Hughes J, Gu W, et al. Phospho-Akt overexpression in non-small cell lung cancer confers significant stage independent survival disadvantage. Clin Cancer Res 2004;10(15):6865-71.

Del Peso L, Garcia MG, Page C, Herrera R, Nunez G. Interleukin-3-induced phosphorylation of BAD though the protein kinase Akt. Science 1997;278(5338):68793.

Delord JP, Allal C, Canal M, Mery M, Rochaix P, Zheng F, et al. Selective inhibition of HER inhibits Akt signal transduction and prolongs disease-free survival in a micrometastasis model of ovarian carcinoma. Ann Ancol 2005;11:1-9.

Dolcet X, Ll'obet D, Pallares J, Matias-Guin X. NFkB in development and progression of human cancer. Virchows Arch 2005;446:475-82.

Douglas-Jones AG, Navabi H, Morgan JM, Jasani B. Immunoreactive p53 and metallothionein expression in duct carcinoma in situ of the breast. No correlation. Virchows Arch 1997;430:373-9. 
Durazzo MD, Araújo CE, Neto BJS, Ade OS, Takeda F, Silva N, et al. Clinical and epidemiological features of oral cancer in a medical school teaching hospital from 1994 to 2002: increasing incidence in women, predominance of advanced local disease, and low incidence of neck metastase. Clinics 2005;60(4):293-8.

Feng J, Tamaskovic R, Yang Z, Brazil PD, Merlo D, Hess D, et al. Stabilization of $\mathrm{mdm} 2$ via decreased ubiquitination is mediated by protein kinase B/Akt-dependent phosphorylation. J Biol Chem 2004;279(34):35510-7.

Fenic I, Steger K, Gruber C, Arens C, Woenckhaus J. Analysis of PIK3CA and Akt/protein kinase $B$ in head and neck squamous cell carcinoma. Oncol Rep 2007;18:253-9.

Fiala ES, Sohn OS, Wang, CX, Seibert E, Tsurutani, J. Induction of preneoplastic lung lesions in guinea pigs by cigarette smoke inhalation and their exacerbation by high dietary levels of vitamins C and E. Carcinogenesis 2005;26:605-12.

Fong LYY, Jiang Y, Farber JL. Zinc deficiency potentiates induction and progression of lingual and esophageal tumors in p53-deficient mice. Carcinogenesis 2006;27:1489-96.

Fradet V, Lessard L, Bégin LR, Karakiewicz P, Masson AMM, Freg $\mathrm{H}$, et al. Nuclear factor-KB nuclear localization is predictive of biochemical recurrence in patients with positive margin prostate cancer. Clin Cancer Res 2004;10:8460-4.

Fujita M, Goto K, Yoshida K, Okamura H, Morimoto H, Okada S, et al. Okadaic acid stimulates expression of fas receptor and fas ligant by activation of nuclear factor kappa-B in human oral squamous carcinoma cells. Oral Oncol 2004;40:199-206.

Goldstein DP, Irish JC. Head and neck squamous cell carcinoma in the young patient. Current Opinion Otolaryngol Haed Neck Surg 2005;13:207-11.

Grille SJ, Bellacosa A, Upson J, Klein-Szanto AJ, Van Roy F, Grenn D, et al. The protein kinase Akt induces epithelial mesenchymal transition and promotes enhanced motility and invasiveness of squamous carcinoma lines. Cancer Res 2003;63:2172-8.

Guler N, Uckan S, Celik I, Oznurlu Y, Uckan D. Expression of fas and fas-ligand and analysis of argyrophilic nucleolar organizer regions in squamous cell carcinoma: relationship with tumor stage and grade and apoptosis. Int J Oral Maxillofac Surg 2005;34:900-6. 
Gupta AK, McKenna WG, Weber CN, Feldman MD, Goldsmith JD, Meckfill B, et al. Local recurrence in head and neck cancer. Clin Cancer Res 2002;8:885-92.

Hacker $\mathrm{H}$, Karin $\mathrm{M}$. Is NFKB2/p100 a direct activator of programmed cell death? Cancer Cell 2002; 33:431-433.

Haddadin KJ, Soutar DS, Webster MHC, Robertson AG, Oliver RJ, Macdonald DG. Natural history and patters of recurrence of tongue tumours. $\mathrm{Br} \mathrm{J}$ Plast Surg 2000; 53: 279-285.

Hah J, Lee K, Choi YJ, Kim W, Park JW, Gu W, et al. Inactive caspase 3 activates Akt in human leukemia cells susceptible or resistant to apoptosis induced by phorbol ester. Int J Oncol 2003;22:1111-6.

Han SW, Khuri FR, Roman J. Fibronectin stimulates non-small lung carcinoma cell grow though activation of Akt/mammalian target of rapamycin/S6 kinase and inactivation of LKB1/AMP-activated protein kinase signal pathways. Cancer Res 2006;66:315-323.

Haq F, Mahoney M, Koropatnick R. Signaling events for metallothionein induction. Mutation Res 2003;533:211-26.

Harada K, Supriatno T, Kawashima Y, Yoshida H, Sato M. S-1 inhibits tumorigenicity and angiogenesis of human oral squamous cell carcinoma cells by supression of phosphorylated Akt, vascular endothelial growth factor and fibroblast growth factor-2. Int J Oncol 2007;30:365-74.

Hay N. The Akt-mTOR tango and its relevance to cancer. Cancer Cell 2005;8:17983.

Hayden MS, Ghosh S. Signaling to NFkB. Gen Develop 2004;18:2195-224.

Hindle I, Dower MC, Moles DR, Speight PM. Is alcohol responsible for more intra-oral cancer? Oral Oncol 2000;36:328-33.

Howie NM, Trigkas TK, Cruchley AT, Wertz PW, Squier CA, Mullet DZ, et al. Shortterm exposure to alcohol increases the permeability of human oral mucosa. Oral Dis 2001;7:349-54. 
$\mathrm{Hu} \mathrm{H}$, Jiang C, Li G, Lu J. PKB/Akt and ERK regulation of caspase-mediated apoptosis by methylseleninic acid in LNCap prostate cancer cells. Carcinogenesis 2005;26(8):1374-81.

Hu TH, Huang CC, Lin PR, Chang HW, Ger LP, Shu VK, et al. Expression and prognostic role of tumor supressor gene PTEN/MMAC1/TEP1 in hepatocellular carcinoma. Cancer 2003;97(8):1929-40.

Husseiny GE, Kandil A, Khafaga AJY, Saleem M, Rajhi NA, Gifh M, et al. Squamous cell carcinoma of the oral tongue: an analysis of prognostic factors. $\mathrm{Br} \mathrm{J}$ Oral Maxillofac Surg 2000;38:193-9.

Ikebe T, Nakayama H, Masanori S, Shirasuna K. NF-kB involvement in tumor-stroma interaction of squamous cell carcinoma. Oral Oncol 2004;40:1048-56.

Iwase M, Takaoka S, Uchida M, Yoshiba S, Kondo G. Epidermal growth factor receptor inhibitors enhance susceptibility to fas-mediated apoptosis in oral squamous cell carcinoma cells. Oral Oncol 2007;56:49-57.

Iype EM, Pandey M, Mathew A, Thomas G, Sebastian P, Petter G, et al. Squamous cell carcinoma of the tongue among young indian adults. Neoplasia 2001;3:273-7.

Jaber MA, Porter SR, Gilthorpe MS, Bedi R, Scully C. Risk factors for oral epithelial dysplasia- the role of smoking and alcohol. Oral Oncol 1999;35:151-6.

Jensen PB, Hunter T. Oncogenic kinase signalling. Nature 2001;411:355-65.

Kanamori Y, Kigawa J, Itamochi H, Shimada M, Takahashi M, Kimura D, et al. Correlation between loss of PTEN expression and Akt phosphorylation in endometrial carcinoma. Clin Cancer Res 2001:892-5.

Kandel ES, Hay N. The regulation and actives of the multifunctional serine/threonine kinase Akt/PKB. Exp Cell Res 1999;253:210-29.

Kanekiyo M, Itoh N, Kawasaki A, Tanaka J, Nakanishi T. Zinc-Induced activation of the human cytomegalovirus major immediate-early promoter is mediated by metallothionein and nuclear factor-kB toxicology and apllied. Pharmacology 2001;173:146-53. 
Kaomongkolgit R, Cheepsunthorn P, Pavasant P, Sanchavanakit N. Iron increases MMP-9 expression through activation of AP-1 via ERK/Akt pathway in human head and neck squamous carcinoma cells. Oral Oncol 2007;11:1-10.

Kari S, Alho OP, Jokinen M, Hyrynkangas K, Laara E. Carcinoma of the oral tongue in northern finland: trends in overall incidence and patient and tumour characteristics. J Oral Pathol Med 1997;26:480-3.

Kasibhatla S, Genestier L, Green DR. Regulation of fas ligant expression during activation-induced cell death in $\mathrm{T}$ lymphocytes via nuclear factor kB. J Biol Chem 1999;274:987-92.

Kikani CK, Dong LK, Liu F. New-clear functions of PDK1: beyong a master kinase? J Cell Biochem 2005;96:1157-62.

Kim CH, Kim JH, Lee J, Ahn YS. Zinc-induced NF-kB inhibition can be modulated by changes in the intracellular metallothionein level. Toxicol Appl Pharmacol 2003;190:189-96.

Kohn KW, Pommier Y. Molecular interaction map of the p53 and Mdm2 logic elements, which control the off-on switch of p53 in response to DNA damage. Biochem Biophys Res Com 2005;331:816-27.

Kondo G, Iwase M, Watanable H, Uchida M, Takaoka S. Enhancement of susceptibility to Fas-mediated apoptosis in oral squamous cell carcinoma by phosphatidylinositol 3-kinase inhibitor. Oral Oncol 2006;42:745-52.

Kondo Y, Woo ES, Michalska AE, Choo KHA, lazo JS. Metallothionein null cells have increased sensitivity to anticancer drugs. Cancer Res 1995;55:2021-3.

Kozaki K, Imoto I, Pimkhaokham A, Hasegawa S, Tsuda H. PIK3CA mutation is an oncogenic aberration at advanced stages of oral squamous cell carcinoma. Cancer Sci 2006;97:1351-8.

Kumar A, Takada Y, Boriek AM, Aggarwal BB. Nuclear factor-kB: its role in health and disease. J Mol Med 2004;82:434-48.

Kwon O, Kim KA, He L, Jung M, Jeong SJ. Complex formation of p65/RelA with nuclear Akt1 for enhanced transcriptional activation of NF-kB. Biochem Biophys Res 2008;365:771-6. 
Lam L, Logan RM, Luke C. Epidemiological analysis of tongue cancer in south Australia for the 24-year period 1977-2001. Aust Dent J 2006;51(1):16-22.

Lee BL, Lee HS, Jung J, Cho SJ, Chung HY, Kim WH, et al. Nuclear factor-KB activation correlates with better prognosis and Akt activation in human gastric cancer. Clin Cancer Res 2005;11(17):2518-25.

Lee TK, Poon RT, Wo JY, Ma S, Guan XY. Lupeol suppresses cisplatin-induced nuclear factor-kappaB activation in head and neck squamous cell carcinoma and inhibits local invasion and nodal metastasis in an orthotopic nude mouse model. Cancer Res 2007;67:8800-9.

Leslie NR, Downes CP. The down side of PI 3-kinase signalling. Cell Signall 2002;14:285-295.

Lessard L, Masson AMM, Lamarre L, Wall L, Lattouf JB, Ghend S, et al. NFKB nuclear localization and its prognostic significance in prostate cancer. BJU Int 2003;91:417-20.

Lewin F, Norell SE, Johansson H, Gustavsson P, Wennerberg J, Nillew F, et al. Smoking tobacco, oral snuff, and alcohol in the etiology of squamous cell carcinoma of the head and neck. Cancer 1998;82:1367-75.

Li X, Stark GR. NF-kB-dependent signaling pathways. Exper Hematol 2002;30:28596.

Lim JHK, Paeng JY, Kim MJ, Hong SD, Lee JI, Hong SP. Prognostic value of activated Akt expression in oral squamous cell carcinoma. J Clin Pathol 2005;58:1199-205.

Lim SC, Zhang S, Ishii G, Endoh Y, Kodama K. Predictive markers for late cervical metastasis in stage I and II invasive squamous cell carcinoma of the oral tongue. Clin Cancer Res 2004;10:166-72.

Llewellyn CD, Johnson NW, Warnakulasuriya KAAS. Risk factors for oral cancer in newly diagnosed patients age 45 years and younger: a case-control study in southern England. J Oral Pathol Med 2004;33:525-32. 
Lung T, Tascau OC, Almasan HA, Muresan O. Head neck cancer, evolution and post therapeutic survival - part 2: a decade's results 1993-2002. J Cranio-Maxillofac Surg 2007;35:126-31.

Luo J, Manning BD, Cantley LC. Targeting the PI3K-Akt patway in human cancer: rationale and promise. Cancer Cell 2002;4:257-62.

Maddika S, Bay GH, Kroczack, TJ, Ande SR, Mandikka EW. Akt is transferred to the nucleus of cells treated with apoptin, and it participates in apoptin-induced cell death. Cell Proliferation 2007;40:835-48.

Maddika S, Mendoza FJ, Hauf K, Zamzow CR, Paranjothy T, Zhun D, et al. Apoptin and its mechanism of action. Cancer Biol Ther 2006;5:10-9.

Malik SN, Brattain M, Ghosh PM, Troyer DA, Prihoda T, Fullic G, et al. Immunohistochemical demonstration of phosphor-Akt in high gleason grade prostate cancer. Clin Cancer Res 2002;8:1168-71.

Mandal M, Younes M, Swan EA, Jasser SA, Doan D. The Akt inhibitor KP372-1 inhibits proliferation and induces apoptosis and anoikis in squamous cell carcinoma of the head and neck. Oral Oncol 2006;42:430-9.

Maret W. The function of zin metallothionein: a link between cellular zinc and redox state. J Nutrition 2000;130:1455-8.

Massareli E, Liu DD, Lee JJ, El-Naggar AK, Muzio LL, Shinn SF, et al. Akt activation correlates with adverse outcome in tongue cancer. Cancer 2005;104:2430-6.

Mayo LD, Donner DB. The PTEN, Mdm2, p53 tumor supressor-oncoprotein network. Trends Biochem Sci 2002;27(9):462-7.

Mayo LD, Dixon JE, Durden DL, Tonks NK, Donner BD. Pten protects p53 from mdm2 and sensitizes cancer cells to chemotherapy. J Biol Chem 2002;277(7):54849.

McCaffrey JC, Weitzner M, Kamboukas D, Haselhuhn G, LaMonde L. Alcoholism, depression, and abnormal cognition in head neck cancer: a pilot study. Otolaryngol Head Neck Surg 2007;136:92-7. 
Meier R, Allessi DR, Cron P, Andjelkovie M, Hemmings BA. Mitogenic activation, phosphorylation, and nuclear translocation of protein kinase $\mathrm{B} \beta$. J Biol Chem $1997 ; 272(48): 30491-7$.

Milne D, Kampanis P, Nicol S, Dias S, Campbell, DG, Pace FF, et al. A novel site of AKT-mediated phosphorylation in the human MDM2 onco-protein. FEBS Letters 2004;577:270-6.

Moynagh PN. The NFkB pathway. J Cell Sci 2005;118:4389-92.

Muraki Y, Tateishi A, Seta C, Fukuda J, Haneji T, Tujymoto J, et al. Fas antigen expression and outcome of oral squamous cell carcinoma. Int $\mathrm{J}$ Oral Maxillofac Surg 2000;29:360-5.

Nakano M, Sogawa CA, Sogawa N, Mishima K, Yamashita E. Expression pattern of cisplatin-induced metallothionein isoforms in squamous cell carcinoma. Anticancer Res 2003;23:299-303.

Nakatani K, Thompson DA, Barthel A, Sakaue H, Liu W, Lu H, et al. Up-regulation of Akt3 in estrogen receptor-deficient breast cancers and androgen-independent prostate cancer lines. Cancer 1999;274(31):21528-32.

Nakayama H, Ikebe T, Beppu M, Shirasuna K. High expression levels of nuclear factor $\mathrm{kB}$, IkB kinase $\alpha$ and Akt kinase in squamous cell carcinoma of the oral cavity. Cancer 2001;92(12):3037-44.

Navolanic P, Steelman LS, McCubrey J.A. EGFR family signaling and its association with breast cancer development and resistance to chemotherapy (Review). Int J Oncol 2003;274(31):21528-32.

Odell EW, Jani P, Sherriff M, Ahluwalia SM, Hibbert J, Levison DA, et al. The prognostic value of individual histologic grading parameters in small lingual squamous cell carcinomas. Cancer 1994;74:789-94.

Oren M, Damalas A, Gottlieb T, Michael D, Taplick J, Leal MFM, et al. Regulation of p53: intricate and delicate balances. Biochem Pharmacol 2002;64:865-71.

Ostrakhovitch EA, Olsson PL, Jiang S, Cherian MG. Interaction of metallothionein with tumor supressor p53 protein. FEBS Letters 2006;580:1235-8. 
Panigrahi AR, Pinder SE, Chan SY, Paish EC, Robertson JFR, Path S, et al. The role of PTEN and its signalling patways, incluinding Akt, in breast cancer; an assessment of relationships with other prognostic factors and with outcome. J Pathol 2004;204:93-100.

Papouli E, Defais M, Larminat F. Overexpression of metallothionein-II sensitizes rodent cells to apoptosis induced by DNA cross-linking agent through inhibition of NF-kB activation. J Biol Chem 2002;227(7):4764-9.

Perkasky Y, Hallas C, Palamarchuk A, Koval A, Bullrich F, Gray D, et al. Akt phosphorylates and regulates the orphan nuclear receptor Nurr77. PNAS 2001;98:3690-4.

Perkins ND. NFkB: tumor promoter or suppressor? Trends Cell Biol 2004;14(2):64-9.

Prado RF, Taveira LAA. Nicotina na carcinogênese química bucal. Rev Bras Patol Oral 2003;2(4):24-7.

Puduvalli VK, Sampath D, Bruner JM, Nanglia J, Xu R, Lim H, et al. TRAIL-induced apoptosis in gliomas is enhanced by Akt-inhibition and is independent of JNK activation. Apoptosis 2005;10:233-43.

Ravi R, Bedi A. NFkB in cancer- a friend turned foe. Drug Resist Updates 2004;7:5367.

Rojo Al, Salinas M, Martín D, Perona R, Cuadrado A. Regulation of Cu/Zn superoside dismutase expression via the phosphatidylinositol 3 kinase/Akt pathway and nuclear factor-kB. J Neurosci 2004;24:7324:34.

Roland NJ, Caslin AW, Nash J, Stell PM. Value of grading squamous cell carcinoma of the head and neck. Head and Neck 1992;14:224-9.

Romashkova JA, Makanov SS. NF-kB is a target of Akt in anti-apoptotic PDGF signaling. Nature 1999;401:86-90.

Romero-Isart N, Vasak $M$. Advances in the structure and chemistry of metallothioneins. J Inorg Biochem 2002;88:388-96. 
Ross JS, Kallakury BVS, Sheehan CE, Fisher HAG, Kaufman RP, Scully S, et al. Expression of nuclear factor- $\mathrm{KB}$ and $\mathrm{I} \mathrm{kB \alpha}$ proteins in prostatic adenocarcinomas: correlation of nuclear factor-kB immunoreactivity with disease recurrence. Clin Cancer Res 2004;10:2466-72.

Sakurai A, Hara S, Okano N, Kondo Y, Inoue J, Imura N. Regulatory role of metallothionein in NF-kB activation. FEBS Leterrs 1999;455:55-8.

Santhi WS, Sebastian P, Varghese BT, Prakash O, Pillai MR. NF-kB and COX-2 during oral tumorigenesis and in assessment of minimal residual disease in surgical margins. Exper Mol Pathol 2006;81:123-30.

Sasaki T, Moles DR, Imai Y, Speight PM. Clinico-pathological features of squamous cell carcinoma of the oral cavity in patients $<40$ years of age. J Oral Pathol Med 2005;34:129-33.

Sasabe E, Tatemoto Y, Li D, Yamamoto T, Osaki T. Mechanism of HIF-1adependent suppression of hypoxia-induced apoptosis in squamous cell carcinoma cells. Cancer Sci 2005;96:394-402.

Sato M, Kondoh M. Recent studies on metallothionein: protection against toxicity of heavy metals and oxygen free radicals. Tohoku J Exper Med 2002;196:9-22.

Schmitz KJ, Garbellus F, Callies R, Wohlschlaeger J, Otterbach, F, Shutz M, et al. Relationship and prognostic significance of phospho-(serine 166)-murine double minute 2 and Akt activation in node-negative breast cancer with regard to p53 expression. Virchow Arch 2006;448(1):16-23.

Schuchmann M, Galle PR. Dead or alive- NFKB, the guardian which tips the balance. J Hepatol 2002;36:827-8.

Scully C, Field J, Tanzawa H. Genetic aberrations in oral or head neck squamous cell carcinoma: carcinogen metabolism, DNA repair and cell cycle control. Oral Oncol 2000;36:256-63.

Shah A, Swain WA, Richardson D, Edwards J, Stewart DJ, Stonne C, et al. PhosphoAkt expression is associated with a favorable outcome in non-small cell lung cancer. Clin Cancer Res 2005;11(8):2930-6. 
She QB, Solit DB, Ye Q, O'Reilly KE, Lobo J, Miller K, et al. The Bad protein integrates survival signaling by EGFR/MAPK and PI3K/Akt kinase pathways in PTEN-deficient tumor cells. Clin Cancer Res 2005;8:287-97.

Shingaki S, Takada M, Sasai K, Bibi R, Kobayashi T, Nokura T, et al. Impact of lymph node metastasis on the pattern of failure and survival in oral carcinomas. Am J Surg 2003;185:278-84.

Singhal S, Vachani A, Ozerkis D, Kaiser L, Albelda S. Prognostic implications of cell cycle, apoptosis, and angiogenesis biomarkers in non-small cell lung cancer: a review. Clin Cancer Res 2005;11(11):3974-85.

Siriwardena BSMS, Tilakaratne A, Amaratunga EAPD, Tilakaratne WW. Demographic, aetiological and survival differences of oral squamous cell carcinoma in the young and the old in Sri Lanka. Neoplasia 2006;42:831-6.

Suh J, Rabson AB. NFkB Activation in human prostate cancer: important mediador or epiphenomenon? J Cell Biochem 2004;91:100-17.

Sundelin K, Jadner M, Norberg-Spaak L, Davidsson A, Hellquist HB. Metallothionein and fas (CD95) are expressed in squamous cell carcinoma of the tongue. Eur $\mathrm{J}$ Cancer 1997;1860-4.

Takada H, Tomizawa K, Matsushita M, Matsui H. 2-methoxyestradiol enhances p53 protein transduction therapy-associated inhibition of the proliferation of oral cancer cells through the suppression of NF-kB activity. Acta Med Okayama 2004;58:181-7.

Takamune $\mathrm{Y}$, Ikebe $\mathrm{T}$, Nagano $\mathrm{O}$, Shinohara M. Involvement of NF-kB mediated maturation of ADAM-17 in the invasion of oral squamous cell carcinoma. Biochem Biophys Res Commun 2008;365:393-8.

Tamatani T, Azuma M, Aota K, Yamashita T, Bando T. Enhanced IkB kinase activity is responsible for the augmented activity of NF-kB in human head and neck carcinoma cells. Cancer Letters 2001;171:165-72.

Tamatani T, Azuma M, Motegi K, Takamaru N, Kawashima Y. Cepharanthinenhanced radiosensitivity through the inhibition of radiation-induced nuclear factor kappaB activity in human oral squamous cell carcinoma cells. Int $\mathrm{J}$ Oncol 2007;31:761-8. 
Tang JM, He QY, Guo RX, Chang XJ. Phosphoryalted Akt overexpression and loss of PTEN expression in non-small cell lung cancer confers poor prognosis. Lung Cancer 2005;3:1-11.

Taniguchi T, Takahashi M, Shinohara F, Sato T, Echigo S, Fugyta W, et al. Involvement of NF-kB and mitochondrial pathways in docetaxel-induced apoptosis of human oral squamous cell carcinoma. Int J Mol Med 2005;15:667-73.

Theocharis SE, Margeli AP, Klijanienko JT, Kouraklis GP. Metallothionein expresssion in human neoplasia. Histopathology 2004;45:103-18.

Thornberry NA, Lasebnik Y. Caspases: enemies within. Science 1998;281:1312-6.

Toker A, Yoeli-Lerner M. Akt signaling and cancer: surviving but not moving on. Cancer Res 2006;15:3963-6.

Toker A, Yoeli-Lerner M. Akt signaling and cancer: surviving but not moving on. Cancer Res. 2006:15:3963-6.

Toker A, Yoeli-Lerner M. Akt signaling and cancer: surviving but not moving on. Cancer Res. 2006:15:3963-6.

Trotman LC, Alimonti A, Scaglioni PP, Koutcher JA, Cordon-Cardo C. Identification of a tumour suppressor network opposing nuclear Akt function. Nature 2006;441:523-7.

Tsujikawa K, Susuki N, Sagawa K, Itoh M, Sugiyama T. Induction and subcellular localization of metallothionein in regenerating rat liver. Eur J Cell Biol 1994;63:240-6.

Tsurutani J, Castillo SS, Brognard J, Granville CA, Zhang C, Lee D, et al. Tobacco components stimulate Akt-dependent proliferation and NF-kB-dependent survival in lung cancer cells. Carcinogenesis 2005;26:1182-95.

Tsurutani J, Fukuoka J, Tsurutani H, Shih JH, Hewitt SM, Heller D, et al. Evaluation of two phosphorylation sites improves the prognostic significance of Akt activation in non-small-cell lung cancer tumors. Clin Oncol 2006;24(2):306-14.

Vara JAF, Casado E, Castro J, Cejas P, Belda C, Baron MG. PI3K/Akt signalling pathway and cancer. Cancer Treatment Rev 2004;30:193-204. 
Vargas H, Pitman KT, Johnson JT, Galati LT. More aggressive behavior of squamous cell carcinoma of the anterior tongue in young women. Laryngoscope 2000;110:1623-6.

Vasak M, Hasler DW. Metallothioneins: new functional and structural insights. Chem Biol 2000;4:177-83.

Vazquez F, Sellers WR. The PTEN tumor supressor protein: an antagonist of phosphoinositide 3-kinase signaling. Biochem Bioph Acta 2000;1470:21-35.

Vestey SB, Sen C, Calder CJ, Perks CM, Pignatelli M, Grytf D, et al. Activated Akt expression in breast cancer: correlation with p53, $\mathrm{Hdm} 2$ and patient outcome. Eur J Cancer 2005; 41:1017-25.

Viglietto G, Motti ML, Fusco A. Understanding p2 $7^{\mathrm{Kp} 1}$ desregulation in cancer. Cell Cycle 2002;1(6):394-400.

Vora HH, Shah NG, Patel DD, Trivedi TI, Chikhlikar PR. Prognostic significance of biomarkers in squamous cell carcinoma of the tongue: multivariate analysis. J Oncol 2003;82:34-50.

Waes CV, Chang AA, Lebowitz PF, Druzgal CH, Chen Z. Inhibition of nuclear factor$\mathrm{kB}$ and target genes during combined therapy with proteasome inhibitor bortezomib and reirradiation in patients with recurrent head neck squamous cell carcinoma. Cancer 2005;63:1400-12.

Warnakulasuriya S, Parkkila S, Nagao T, Preedy VR, Pasanen M, Heidi K, et al. Demonstration of ethanol-induced protein adducts in oral leukoplakia and cancer. J Oral Pathol Med 2008;37:157-65.

West KA, Brognard J, Clarck AS, Linnoila IR, Yang X. Rapid Akt activation by nicotine and tobacco carcinogen modulates the phenotype of normal human airway epithelial cells. J Clin Invest 2003;111:81-90.

West KA, Castilo SS, Dennis PA. Activation of the PI3K/Akt pathways and chemotherapeutic resistance. Drug Resist Updates 2002;5:234-48.

Yamamoto Y, Gaynor RB. IKB kinases: key regulators of the NFKB pathway. Trends Biochem Sci 2004;29 (2):72-9. 
Yang E, Zha J, Jockel J, Boise LH, Thompson CB, Korsmeyer SJ. Control of apoptosis by NF-kB pathway. Cell 1995;80:285-91.

Yao J, Duan L, Fan M, Wu X. NF-kB signaling pathway is involved in growth inhibition, G2/M arrest and apoptosis induced by trichostatin $A$ in human tongue carcinoma cells. Pharmacol Res 2006;54:406-13.

Yao J, Duan L, Fan M, Wu X. Y-secretase inhibitors exerts antitumor activity via down-regulation of notch and nuclear factor kappa $B$ in human tongue carcinoma cells. Oral Dis 2007;13:555-63.

Yu Z, Weinberg PM, Sasaki C, Egleston BL, Speier WF. Phosphorylation of Akt (Ser 473) predicts poor clinical outcome in oropharyngeal squamous cell cancer. Cancer Epidemiol Biomarkers 2007;16:553-8.

Zhang H, Bajraszewwski N, Wu E, Moseman HW, Dabora SL. PDGFRs are critical for PI3K/Akt activation and negative mTOR. J Clin Invest 2007;117:730-8.

Zhang P, Ostrander JH, Faivre E, Olsen A, Fitzsimmons D. Regulated association of protein kinase B/Akt with breast tumor kinase. J Biol Chem 2005;280(3):1982-91.

Zhou BP, Liao Y, Xia W, Zou Y, Spohn B, Hung MC. HER-2/neu induces p53 ubiquitinization via Akt-mediated MDM2 phosphorylation. Nature Cell Biol 2001;3:973-83.

Zhou Y, Castori S, Eppenberg U, Benz C. The NFKB pathways and endocrineresistant breast cancer. Endocrine Related Cancer 2005a;12:37-46.

Zhou Y, Castori E, Marx C, Yau C, Scott G. Activation of nuclear factor-kB (NFkB) identifies a high-risk subset of hormone-dependent breast cancers. Int $\mathrm{J}$ Biochem Cell Biol 2005b;37:1130-44. 
